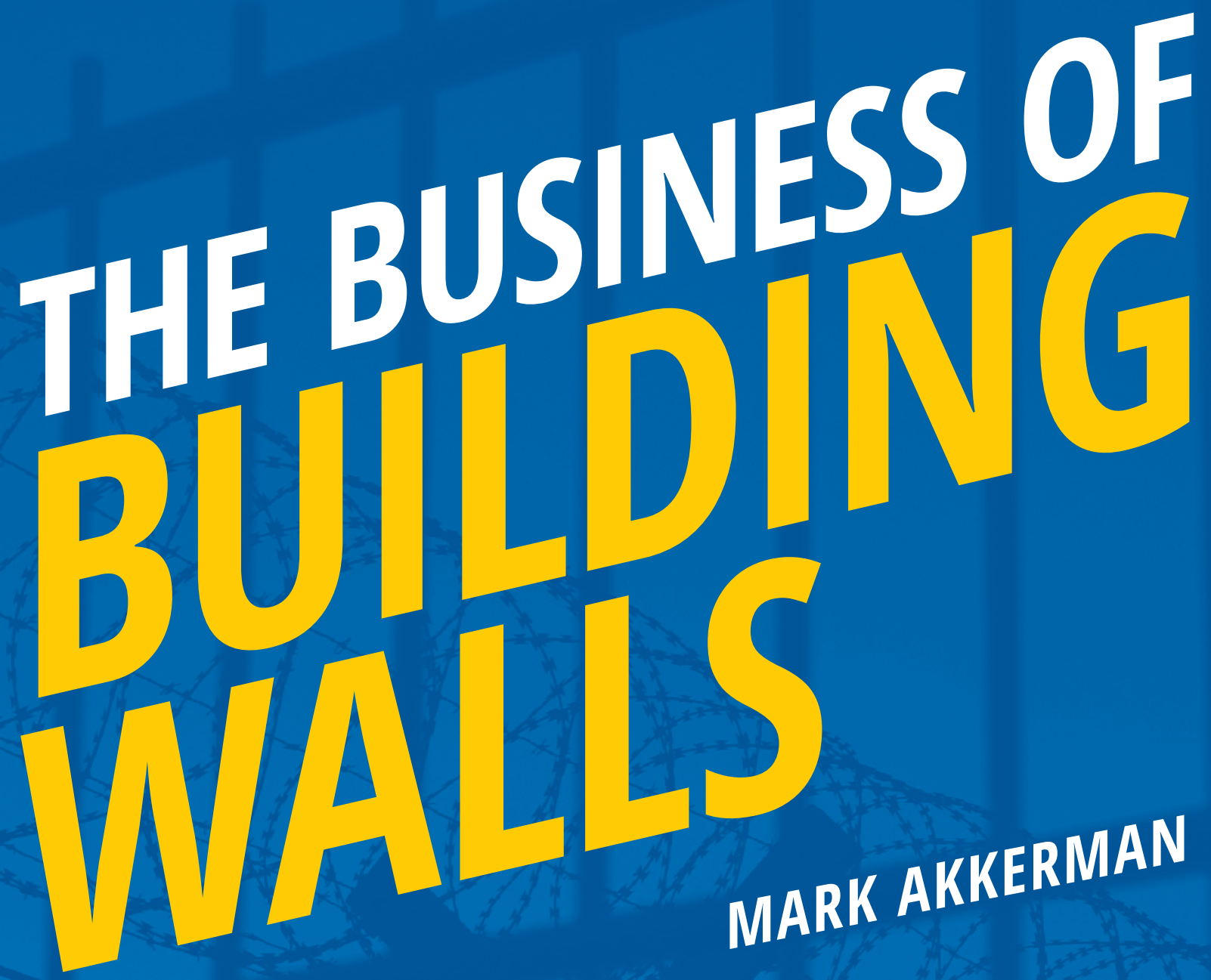

Stop
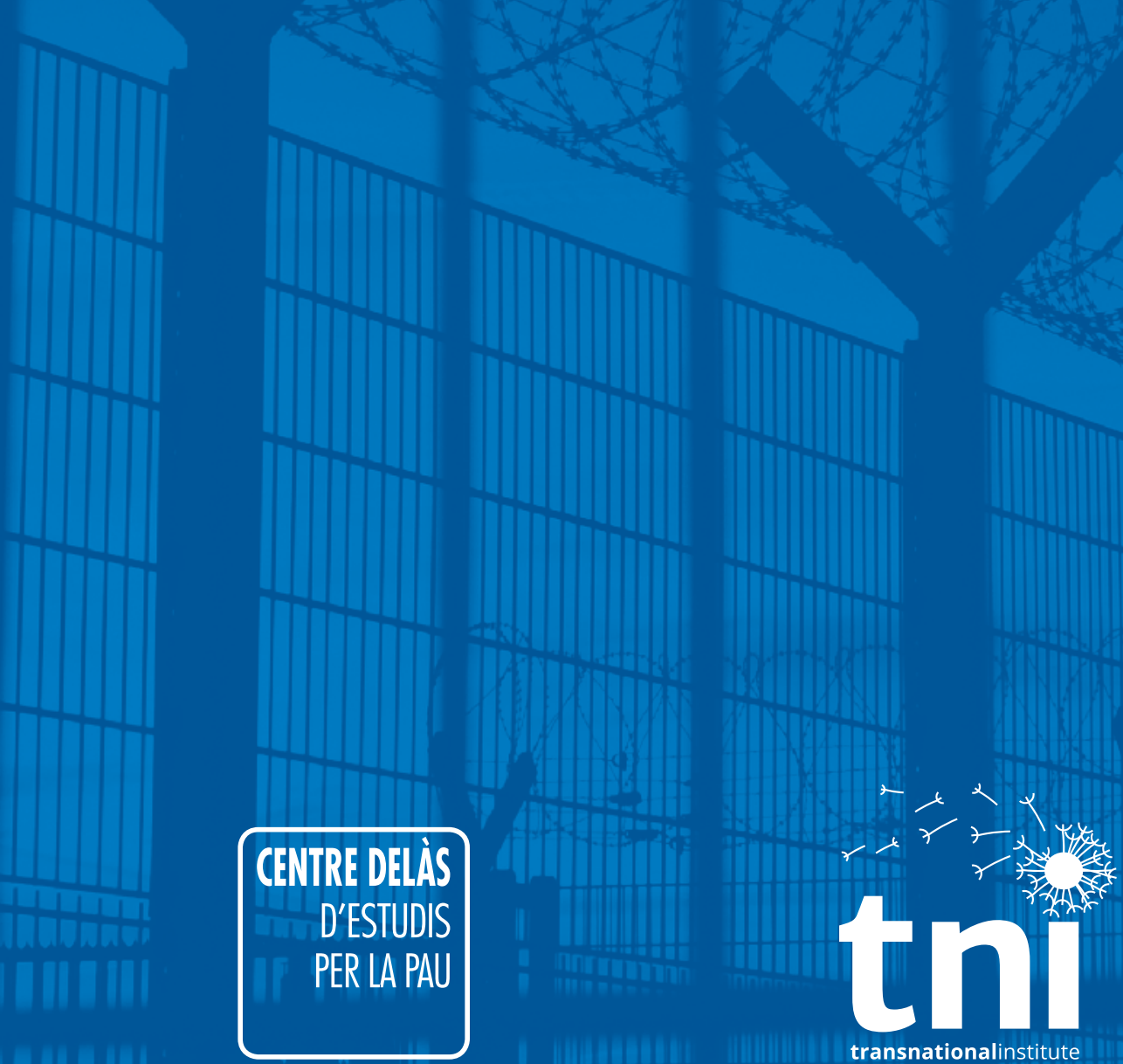
AUTHOR: Mark Akkerman

EDITORS: Nick Buxton, Niamh Ní Bhriain

COPYEDITOR: Deborah Eade

DESIGN: Evan Clayburg

PRINTER: Jubels

PHotos: Cover @wwworks/Flickr, p13 @mindefensa/Flickr, p19 @ejercitoaire/Flickr, p25 Freedom House (@syriafreedom/Flickr), p28 Sara Prestianni (@SaraPrestianni/ Flickr), Back Cover Sébastien Bertrand (@tiseb/Flickr)

Published by:

Transnational Institute - www.TNI.org

Stop Wapenhandel - www.stopwapenhandel.org

Centre Delàs - www.centredelas.org

\section{November 2019}

Contents of the report may be quoted or reproduced for non-commercial purposes, provided that the source is properly cited. TNI would appreciate receiving a copy of or link to the text in which it is used or cited. Please note that the copyright for the images remains with the photographers.

http://www.tni.org/copyright

\section{ACKNOWLEDGEMENTS}

Thanks to Janis Brizga, Laura Gintalaitè, Ainhoa Ruiz and Border-monitoring Bulgaria for their help in gathering information. 


\section{CONTENTS}

$\begin{array}{ll}\text { Executive summary } & 1\end{array}$

$\begin{array}{ll}\text { Introduction } & 8\end{array}$

$\begin{array}{ll}\text { Militarising the border } & 10\end{array}$

$\begin{array}{ll}\text { Europe's many kinds of walls } & 13\end{array}$

Costs and funding of Europe's walls 15

$\begin{array}{ll}\text { Land walls } & 16\end{array}$

Maritime walls 18

Virtual walls $\quad 22$

Border walls industry $\quad 29$

Border security market $\quad 29$

Companies building walls $\quad 29$

The big players $\quad 30$

Land wall contractors $\quad 36$

Maritime wall contractors $\quad 43$

Virtual wall contractors $\quad 48$

Lobbying $\quad 52$

$\begin{array}{ll}\text { Conclusion } & 56\end{array}$ 


\section{EXECUTIVE SUMMARY}

Thirty years after the fall of the Berlin Wall, Europe is once again known for its border walls. This time Europe is divided not so much by ideology as by perceived fear of refugees and migrants, some of the world's most vulnerable people.

Who killed the dream of a more open Europe? What gave rise to this new era of walls? There are clearly many reasons - the increasing displacement of people by conflict, repression and impoverishment, the rise of security politics in the wake of 9/11, the economic and social insecurity felt across Europe after the 2008 financial crisis - to name a few. But one group has by far the most to gain from the rise of new walls - the businesses that build them. Their influence in shaping a world of walls needs much deeper examination.

This report explores the business of building walls, which has both fuelled and benefited from a massive expansion of public spending on border security by the European Union (EU) and its member states. Some of the corporate beneficiaries are also global players, tapping into a global market for border security estimated to be worth approximately $€ 17.5$ billion in 2018 , with annual growth of at least $8 \%$ expected in coming years.

It is important to look both beyond and behind Europe's walls and fencing, because the real barriers to contemporary migration are not so much the fencing, but the vast array of technology that underpins it, from the radar systems to the drones to the surveillance cameras to the biometric fingerprinting systems. Similarly, some of Europe's most dangerous walls are not even physical or on land. The ships, aircrafts and drones used to patrol the Mediterranean have created a maritime wall and a graveyard for the thousands of migrants and refugees who have no legal passage to safety or to exercise their right to seek asylum.

This renders meaningless the European Commission's publicized statements that it does not fund walls and fences. Commission spokesperson Alexander Winterstein, for example, rejecting Hungary's request to reimburse half the costs of the fences built on its borders with Croatia and Serbia, said: 'We do support border management measures at external borders. These can be surveillance measures. They can be border control equipment...But fences, we do not finance'. In other words, the Commission is willing to pay for anything that fortifies a border as long as it is not seen to be building the walls themselves.

This report is a sequel to Building Walls - Fear and securitization in the European Union, co-published in 2018 with Centre Delàs and Stop Wapenhandel, which first measured and identified the walls that crisscross Europe. This new report focuses on the businesses that have profited from three different kinds of wall in Europe:

- the construction companies contracted to build the land walls built by EU member states and the Schengen Area together with the security and technology companies that provide the necessary accompanying technology, equipment and services; 
- the shipping and arms companies that provide the ships, aircraft, helicopters, drones that underpin Europe's maritime walls seeking to control migratory flows in the Mediterranean, including Frontex operations, Operation Sophia and Italian operation Mare Nostrum;

- and the IT and security companies contracted to develop, run, expand and maintain EU's systems that monitor the movement of people - such as SIS II (Schengen Information System) and EES (Entry/ Exit Scheme) - which underpin Europe's virtual walls.

\section{BOOMING BUDGETS}

The flow of money from taxpayers to wall-builders has been highly lucrative and constantly growing. The report finds that companies have reaped the profits from at least $\mathbf{€ 0 0 0}$ million spent by EU countries on land walls and fences since the end of the Cold War. The partial data (in scope and years) means actual costs will be at least $€ 1$ billion. In addition, companies that provide technology and services that accompany walls have also benefited from some of the steady stream of funding from the EU - in particular the External Borders Fund ( $€$ 1.7 billion, 2007-2013) and the Internal Security Fund - Borders Fund (€2.76 billion, 2014-2020).

EU spending on maritime walls has totalled at least €676.4 million between 2006 to 2017 (including $€ 534$ million spent by Frontex, €28.4 million spent by the EU on Operation Sophia and €114 million spent by Italy on Operation Mare Nostrum) and would be much more if you include all the operations by Mediterranean country coastguards. Total spending on Europe's virtual wall equalled at least $€ 999.4 \mathrm{~m}$ between 2000 and 2019. (All these estimates are partial ones because walls are funded by many different funding mechanisms and due to lack of data transparency).

This boom in border budgets is set to grow. Under its budget for the next EU budget cycle (2021-2027) the European Commission has earmarked $€ \mathbf{8 . 0 2}$ billion to its Integrated Border Management Fund (2021-2027), €11.27bn to Frontex (of which $€ 2.2$ billion will be used for acquiring, maintaining and operating air, sea and land assets) and at least $€ 1.9$ billion total spending (2000-2027) on its identity databases and Eurosur (the European Border Surveillance System).

\section{THE BIG ARM INDUSTRY PLAYERS}

Three giant European military and security companies in particular play a critical role in Europe's many types of borders. These are Thales, Leonardo and Airbus.

- Thales is a French arms and security company, with a significant presence in the Netherlands, that produces radar and sensor systems, used by many ships in border security. Thales systems, were used, for example, by Dutch and Portuguese ships deployed in Frontex operations. Thales also produces maritime surveillance systems for drones and is working on developing border surveillance infrastructure for Eurosur, researching how to track and control refugees before they reach Europe by using smartphone apps, as well as exploring the use of High Altitude Pseudo Satellites (HAPS) for border security, for the European Space Agency and Frontex. Thales currently provides the security system for the highly militarised port in Calais. Its acquisition in 2019 of Gemalto, a large (biometric) identity security company, makes it a significant player in the development and maintenance of EU's virtual walls. It has participated in $27 \mathrm{EU}$ research projects on border security. 
- Italian arms company Leonardo (formerly Finmeccanica or Leonardo-Finmeccanica) is a leading supplier of helicopters for border security, used by Italy in the Mare Nostrum, Hera and Sophia operations. It has also been one of the main providers of UAVs (or drones) for Europe's borders, awarded a €67.1 million contract in 2017 by the European Maritime Safety Agency (EMSA) to supply them for EU coast-guard agencies. Leonardo was also a member of a consortium, awarded €142.1 million in 2019 to implement and maintain EU's virtual walls, namely its EES. It jointly owns Telespazio with Thales, involved in EU satellite observation projects (REACT and Copernicus) used for border surveillance. Leonardo has participated in $24 \mathrm{EU}$ research projects on border security and control, including the development of Eurosur.

- Pan-European arms giant Airbus is a key supplier of helicopters used in patrolling maritime and some land borders, deployed by Belgium, France, Germany, Greece, Italy, Lithuania and Spain, including in maritime Operations Sophia, Poseidon and Triton. Airbus and its subsidiaries have participated in at least 13 EU-funded border security research projects including OCEAN2020, PERSEUS and LOBOS.

- The significant role of these arms companies is not surprising. As Border Wars (2016), showed these companies through their membership of the lobby groups - European Organisation for Security (EOS) and the AeroSpace and Defence Industries Association of Europe (ASD) - have played a significant role in influencing the direction of EU border policy. Perversely, these firms are also among the top four biggest European arms dealers to the Middle East and North Africa, thus contributing to the conflicts that cause forced migration.

Indra has been another significant corporate player in border control in Spain and the Mediterranean. It won a series of contracts to fortify Ceuta and Melilla (Spanish enclaves in northern Morocco). Indra also developed the SIVE border control system (with radar, sensors and vision systems), which is in place on most of Spain's borders, as well as in Portugal and Romania. In July 2018 it won a $€ 10$ million contract to manage SIVE at several locations for two years. Indra is very active in lobbying the EU and is a major beneficiary of EU research funding, coordinating the PERSEUS project to further develop Eurosur and the Seahorse Network, a network between police forces in Mediterranean countries (both in Europe and Africa) to stop migration.

Israeli arms firms are also notable winners of EU border contracts. In 2018, Frontex selected the Heron drone from Israel Aerospace Industries for pilot-testing surveillance flights in the Mediterranean. In 2015, Israeli firm Elbit Systems sold six of its Hermes UAVs to the Switzerland's Border Guard, in a controversial €230 million deal. It has since signed a UAV contract with the European Maritime Safety Agency (EMSA), as a subcontractor for the Portuguese company CEIIA (2018), as well as contracts to supply technology for three patrol vessels for the Hellenic Coast Guard (2019).

\section{LAND WALL CONTRACTORS}

Most of the walls and fences that have been rapidly erected across Europe have been built by national construction companies, but one European company has dominated the field: European Security Fencing, a Spanish producer of razor wire, in particular a coiled wire known as concertinas. It is most known for the razor wire on the fences around Ceuta and Melilla. It also delivered the razor wire for the fence on the border between Hungary and Serbia, and its concertinas were installed on the borders between Bulgaria and Turkey and Austria and Slovenia, as well as at Calais, and for a few days on the border between Hungary and Slovenia before being removed. Given its long-term market monopoly, its concertinas are very likely used at other borders in Europe. 
Other contractors providing both walls and associated technology include DAT-CON (Croatia, Cyprus, Macedonia, Moldova, Slovenia and Ukraine), Geo Alpinbau (Austria/Slovenia), Indra, Dragados, Ferrovial, Proyectos Y Tecnología Sallén and Eulen (Spain/Morocco), Patstroy Bourgas, Infra Expert, Patengineeringstroy, Geostroy Engineering, Metallic-Ivan Mihaylov and Indra (Bulgaria/ Turkey), Nordecon and Defendec (Estonia/Russia), DAK Acélszerkezeti Kft and SIA Ceḷu būvniecības sabiedrība IGATE (Latvia/Russia), Gintrèja (Lithuania/Russia), Minis and Legi-SGS(Slovenia/Croatia), Groupe CW, Jackson's Fencing, Sorhea, Vinci/Eurovia and Zaun Ltd (France/UK).

In many cases, the actual costs of the walls and associated technologies exceed original estimates. There have also been many allegations and legal charges of corruption, in some cases because projects were given to corporate friends of government officials. In Slovenia, for example, accusations of corruption concerning the border wall contract have led to a continuing three-year legal battle for access to documents that has reached the Supreme Court. Despite this, the EU's External Borders Fund has been a critical financial supporter of technological infrastructure and services in many of the member states' border operations. In Macedonia, for example, the EU has provided $€ 9$ million for patrol vehicles, night-vision cameras, heartbeat detectors and technical support for border guards to help it manage its southern border.

\section{MARITIME WALL PROFITEERS}

The data about which ships, helicopters and aircraft are used in Europe's maritime operations is not transparent and therefore it is difficult to get a full picture. Our research shows, however, that the key corporations involved include the European arms giants Airbus and Leonardo, as well as large shipbuilding companies including Dutch Damen and Italian Fincantieri.

Damen's patrol vessels have been used for border operations by Albania, Belgium, Bulgaria, Portugal, the Netherlands, Romania, Sweden and the UK as well as in key Frontex operations (Poseidon, Triton and Themis), Operation Sophia and in supporting NATO's role in Operation Poseidon. Outside Europe, Libya, Morocco, Tunisia and Turkey use Damen vessels for border security, often in cooperation with the EU or its member states. Turkey's $€ 20$ million purchase of six Damen vessels for its coast guard in 2006, for example, was financed through the EU Instrument contributing to Stability and Peace (IcSP), intended for peace-building and conflict prevention.

The sale of Damen vessels to Libya unveils the potential troubling human costs of this corporate trade. In 2012, Damen supplied four patrol vessels to the Libyan Coast Guard, sold as civil equipment in order to avoid a Dutch arms export license. Researchers have since found out, however, that the ships were not only sold with mounting points for weapons, but were then armed and used to stop refugee boats. Several incidents involving these ships have been reported, including one where some 20 or 30 refugees drowned. Damen has refused to comment, saying it had agreed with the Libyan government not to disclose information about the ships.

In addition to Damen, many national shipbuilders play a significant role in maritime operations as they were invariably prioritised by the countries contributing to each Frontex or other Mediterranean operation. Hence, all the ships Italy contributed to Operation Sophia were built by Fincantieri, while all Spanish ships come from Navantia and its predecessors. Similarly, France purchases from DCN/ DCNS, now Naval Group, and all German ships were built by several German shipyards (Flensburger 
Schiffbau-Gesellschaft, HDW, Lürssen Gruppe). Other companies in Frontex operations have included Greek company, Motomarine Shipyards, which produced the Panther 57 Fast Patrol Boats used by the Hellenic Coast Guard, Hellenic Shipyards and Israel Shipyards.

Austrian company Schiebel is a significant player in maritime aerial surveillance through its supply of S-100 drones. In November 2018, EMSA selected the company for a €24 million maritime surveillance contract for a range of operations including border security. Since 2017, Schiebel has also won contracts from Croatia, Denmark, Iceland, Italy, Portugal and Spain. The company has a controversial record, with its drones sold to a number of countries experiencing armed conflict or governed by repressive regimes such as Libya, Myanmar, the UAE and Yemen.

Finland and the Netherlands deployed Dornier aircraft to Operation Hermes and Operation Poseidon respectively, and to Operation Triton. Dornier is now part of the US subsidiary of the Israeli arms company Elbit Systems. CAE Aviation (Luxembourg), DEA Aviation (UK) and EASP Air (Netherlands) have all received contracts for aircraft surveillance work for Frontex. Airbus, French Dassault Aviation, Leonardo and US Lockheed Martin were the most important suppliers of aircraft used in Operation Sophia.

The EU and its member states defend their maritime operations by publicising their role in rescuing refugees at sea, but this is not their primary goal, as Frontex director Fabrice Leggeri made clear in April 2015, saying that Frontex has no mandate for 'proactive search-and-rescue action[s]' and that saving lives should not be a priority. The thwarting and criminalisation of NGO rescue operations in the Mediterranean and the frequent reports of violence and illegal refoulement of refugees, also demonstrates why these maritime operations should be considered more like walls than humanitarian missions.

\section{VIRTUAL WALLS}

The major EU contracts for the virtual walls have largely gone to two companies, sometimes as leaders of a consortium. Sopra Steria is the main contractor for the development and maintenance of the Visa Information System (VIS), Schengen Information System (SIS II) and European Dactyloscopy (Eurodac), while GMV has secured a string of contracts for Eurosur. The systems they build help control, monitor and surveil people's movements across Europe and increasingly beyond.

Sopra Steria is a French technology consultancy firm that has to date won EU contracts worth a total value of over $€ 150$ million. For some of these large contracts Sopra Steria joined consortiums with HP Belgium, Bull and 3M Belgium. Despite considerable business, Sopra Steria has faced considerable criticism for its poor record on delivering projects on time and on budget. Its launch of SIS II was constantly delayed, forcing the Commission to extend contracts and increase budgets. Similarly, Sopra Steria was involved in another consortium, the Trusted Borders consortium, contracted to deliver the UK e-Borders programme, which was eventually terminated in 2010 after constant delays and failure to deliver. Yet it continues to win contracts, in part because it has secured a near-monopoly of knowledge and access to EU officials. The central role that Sopra Steria plays in developing these EU biometric systems has also had a spin-off effect in securing other national contracts, including with Belgium, Bulgaria, Czech Republic, Finland, France, Germany, Romania and Slovenia. 
GMV, a Spanish technology company, has received a succession of large contracts for Eurosur, ever since its testing phase in 2010 , worth at least $€ 25$ million. It also provides technology to the Spanish Guardia Civil, such as control centres for its Integrated System of External Vigilance (SIVE) border security system as well as software development services to Frontex. It has participated in at least ten EU-funded research projects on border security.

Most of the large contracts for the virtual walls that did not go to consortia including Sopra Steria were awarded by eu-LISA (European Union Agency for the Operational Management of Large-Scale IT Systems in the Area of Freedom, Security and Justice) to consortia comprising computer and technology companies including Accenture, Atos Belgium and Morpho (later renamed Idemia).

\section{LOBBYING}

As research in our Border Wars series has consistently shown, through effective lobbying, the military and security industry has been very influential in shaping the discourse of EU security and military policies. The industry has succeeded in positioning itself as the experts on border security, pushing the underlying narrative that migration is first and foremost a security threat, to be combatted by security and military means. With this premise, it creates a continuous demand for the ever-expanding catalogue of equipment and services the industry supplies for border security and control.

Many of the companies listed here, particularly the large arms companies, are involved in the European Organisation for Security (EOS), the most important lobby group on border security. Many of the IT security firms that build EU's virtual walls are members of the European Association for Biometrics (EAB). EOS has an 'Integrated Border Security Working Group' to 'facilitate the development and uptake of better technology solutions for border security both at border checkpoints, and along maritime and land borders'. The working group is chaired by Giorgio Gulienetti of the Italian arms company Leonardo, with Isto Mattila (Laurea University of Applied Science) and Peter Smallridge of Gemalto, a digital security company recently acquired by Thales.

Company lobbyists and representatives of these lobby organisations regularly meet with EU institutions, including the European Commission, are part of official advisory committees, publish influential proposals, organise meetings between industry, policy-makers and executives and also meet at the plethora of military and security fairs, conferences and seminars. Airbus, Leonardo and Thales together with EOS held 226 registered lobbying meetings with the European Commission between 2014 and 2019. In these meetings representatives of the industry position themselves as the experts on border security, presenting their goods and services as the solution for 'security threats' caused by immigration. In 2017, the same group of companies and EOS spent up to $€ 2.65$ million on lobbying.

A similar close relationship can be seen on virtual walls, with the Joint Research Centre of the European Commission arguing openly for public policy to foster the 'emergence of a vibrant European biometrics industry'. 


\section{A DEADLY TRADE AND A CHOICE}

The conclusion of this survey of the business of building walls is clear. A Europe full of walls has proved to be very good for the bottom line of a wide range of corporations including arms, security, IT, shipping and construction companies. The EU's planned budgets for border security for the next decade show it is also a business that will continue to boom.

This is also a deadly business. The heavy militarisation of Europe's borders on land and at sea has led refugees and migrants to follow far more hazardous routes and has trapped others in desperate conditions in neighbouring countries like Libya. Many deaths are not recorded, but those that are tracked in the Mediterranean show that the proportion of those who drown trying to reach Europe continues to increase each year.

This is not an inevitable state of affairs. It is both the result of policy decisions made by the EU and its member states, and corporate decisions to profit from these policies. In a rare principled stand, German razor wire manufacturer Mutanox in 2015 stated it would not sell its product to the Hungarian government arguing: 'Razor wire is designed to prevent criminal acts, like a burglary. Fleeing children and adults are not criminals'. It is time for other European politicians and business leaders to recognise the same truth: that building walls against the world's most vulnerable people violates human rights and is an immoral act that history will judge harshly. Thirty years after the fall of the Berlin Wall, it is time for Europe to bring down its new walls. 


\section{INTRODUCTION}

The fall of the Berlin Wall in 1989 and the end of the Cold War gave many Europeans hope for a future free from divisiveness in a new era of peace. Now, 30 years later, European countries have constructed about 1000 kilometres of border walls and fences, more than six times the length of the Berlin Wall, to keep out refugees and migrants. Most of these have been built since 2015, when Syria's civil war was at its height. ${ }^{1}$

In many of the countries from which refugees and migrants seek to reach Europe, war, repression, human rights violations, poverty and hunger force people to leave their homes. In many cases, European Union (EU) policies are a contributing factor to these causes of migration. Worldwide, there has been an increase in forcibly displaced people from 43.3 million in 2009 to 70.8 million in $2018 .{ }^{2}$ While about $80 \%$ move within their own country of origin or to neighbouring countries, a small number try to find their way to safety and a better future in Europe. ${ }^{3}$ They are met, however with militarised walls and other draconian security measures intended to keep them out of Europe, and even from reaching its borders in the first place. The Mediterranean has become Europe's graveyard - and a stain on our conscience - for thousands of people who have died trying to reach Europe. ${ }^{4}$

Land walls and fences on European borders are the most visible aspects of Fortress Europe. By themselves, though, they are mostly symbolic, since, as Reece Jones, a university professor of Geography and Environment and specialised in border walls, writes, they are 'not particularly effective at stopping migration on their own. They require constant surveillance by agents, high tech sensors, aircraft, and drones or else they can easily be climbed with a ladder'. ${ }^{5}$ Elisabeth Vallet, an adjunct professor in Geography and also an expert on border fences, adds that the new European border walls 'are designed to calm the identity crisis that they have inside their countries. A wall is an answer to political insecurity inside the country, it's not an answer to the problem it says it will be solving, which is immigration'. ${ }^{6}$

Back in in 2009, the US Congressional Research Service (CRS) had already concluded that a border fence in San Diego 'by itself, did not have a discernible impact on the influx of unauthorized aliens coming across the border in San Diego', and that the main result was that 'the flow of illegal immigration... shifted to the more remote areas of the Arizona desert'. ${ }^{7}$ According to Vallet, walls 'don't prevent people from coming in. It will make it more difficult so people will go through smugglers, will pay a higher price, either monetarily or with their lives to cross the border'. ${ }^{8}$ With this in mind, ' $[t]$ he cost of a massive border infrastructure [...] typically involves not just a physical wall with stone foundations, posts, and even concrete panels, but also razor wire, cameras, heat sensors, movement detectors, drones and patrol personnel, dogs or robots, among other things'. ${ }^{9}$

In November 2018, Centre Delàs, the Transnational Institute (TNI) and Stop Wapenhandel published Building Walls: Fear and Securitization in the European Union, which investigated the land walls and other forms of European anti-migration walls. These included maritime 'walls', built by EU and member states 
maritime operations and obstruction of non-government organisation (NGO) 'search and rescue' activities. ${ }^{10}$ The report also discussed the 'virtual walls' based on databases with (biometric) identity information.

This extensive and complex infrastructure makes the business of border walls and fences an attractive market for the military and security industries. Their main interest is not the fences and walls themselves - which are largely built by construction companies - but the more costly technologies, systems, goods and services that support this land and maritime infrastructure. Arms and security companies have become the biggest corporate beneficiaries in this market.

The Building Walls report connected the (ongoing) increase of physical walls to the rise of 'mental walls': the growth of xenophobia and anti-immigration rhetoric promoted by extreme-right parties in Europe, and often adopted or internalised by more centrist parties. ${ }^{11}$ The 2019 European Parliament elections witnessed further advances of far-right MEPs. ${ }^{12}$ More perniciously, it was also echoed in the political agenda presented by the new president of the European Commission, Dr Ursula von der Leyen: 'We must address and allay legitimate fears and concerns about the impact of irregular migration on our economy and society', and introduced the new Commission portfolio 'Protection of European Way of Life' as an answer. ${ }^{13}$ Von der Leyen's choice of words met with major criticism. UK Green MEP Molly Scott Cato said: 'This looks like the portfolio to fight back against the rise of the fascists, but only by adopting their divisive rhetoric around "strong borders"'.14

This divisive rhetoric and the resulting expansion and strengthening of Fortress Europe seem to be setting the course for European policies and spending for years to come. This report explores the business of building walls - their financial costs, EU funding for them, and the companies that profit. 


\section{MILITARISING THE BORDER}

This report is part of the 'Border Wars' series, initiated and published by $\mathrm{TNI}$ in cooperation with several partner organisations. The series looks at the interests and influences that shape border policy globally. Previous publications focused on the militarisation of European and US borders, the military and security companies lobbying for and profiting from this, and the externalisation of European borders and its consequences.

Two of the key reports - Border Wars (2016) and More than A Wall (2019) - revealed a strong correlation in how border policy was developed in the United States and the EU:

- EU and US border and migration policies are based on a framework in which migration and refugees are treated as a security threat, to be dealt with by 'fight[ing] against illegal immigration', and increasingly by using (para)military personnel and equipment;

- the US and European policy response has led to a booming border security market, building fences, providing equipment for border guards and establishing surveillance systems;

- the arms and security industries helped shape European and US border security policy, from which they now profit as a result of lobbying, regular interactions with EU's border institutions and shaping of EU research policy;

- in the EU context, Border Wars also showed that the same industry selling arms to the Middle East and North Africa, fuelling the conflicts, repression and human rights violations that have led to forcible displacement, is also the main beneficiary of EU border security contracts.

TNI also explored how this border-industrial complex participated in the EU's efforts to externalise its border policies to neighbouring countries. Expanding the Fortress showed that:

- Since 1992, and more aggressively since 2005, the EU has developed a policy of externalising Europe's border so that forcibly displaced people never reach Europe's borders in the first place. These policies involve funding and agreements with Europe's neighbouring countries to accept deportees and adopt the same policies of border control, enhanced tracking of people and fortified borders such as those around Europe;

- Many of the third-country governments receiving EU border security support are highly authoritarian, and the support they receive is often going to precisely those state security organs most responsible for repression and violation of human rights;

- EU border externalisation policies have far-reaching consequences. The most affected are forcibly displaced persons, but they also undermine the economic and social development of (mainly) African nations, compelling them to maintain neo-colonial relations, and strengthening repressive governments - all of which makes forced displacement more likely and therefore undermines even the EU's stated goals. 


\section{BORDER WARS SERIES}

Border Wars: The arms dealers profiting from Europe's refugee tragedy - TNI and Stop Wapenhandel (July 2016)

Border Wars II: An update on the arms dealers profiting from Europe's refugee tragedy - TNI and Stop Wapenhandel (December 2016)

Expanding the Fortress: The policies, the profiteers and the people shaped by EU's border externalisation programme - TNI and Stop Wapenhandel (May 2018)

Building Walls: Fear and securitization in the European Union - Centre Delàs, TNI and Stop Wapenhandel (November 2018)

More Than A Wall: Corporate profiteering and the militarization of US borders - TNI and No More Deaths/No Más Muertes (September 2019)
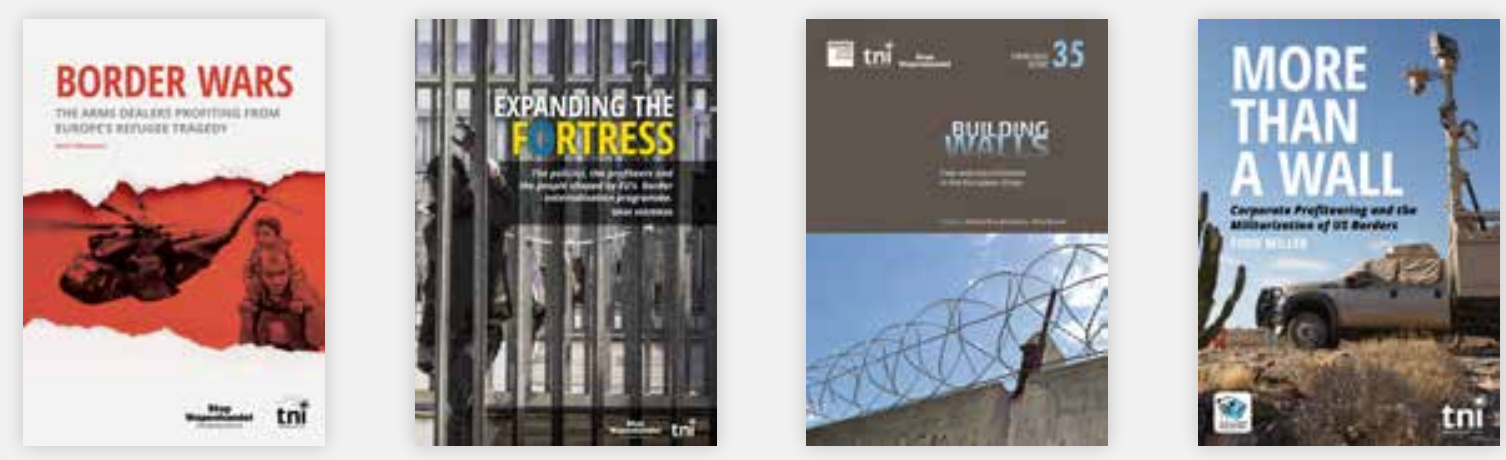

\section{BUILDING WALLS}

In 2018, TNI and Stop Wapenhandel co-published the report Building Walls: Fear and securitization in the European Union, written by Ainhoa Ruiz Benedicto and Pere Brunet of Centre Delàs. It examined the different kinds of walls that have emerged in the last decades in the EU, showing that:

Since the 1990s, EU member states and countries in the Schengen Area have constructed almost 1000 $\mathrm{km}$ of land walls, more than six times the length of the Berlin Wall, to prevent migration to Europe. These physical walls are accompanied by even longer 'maritime walls', naval operations patrolling the Mediterranean and before the Canary Islands which extend another 4750 kilometres. ${ }^{15}$ And finally there are the 'virtual walls', border-control systems that seek to stop people entering or even travelling within Europe, and which control population movements.

These walls are stoked by xenophobic parties that have grown in popularity and exercise an undue influence on European policy. 


\section{BORDER WALLS ${ }^{16}$}

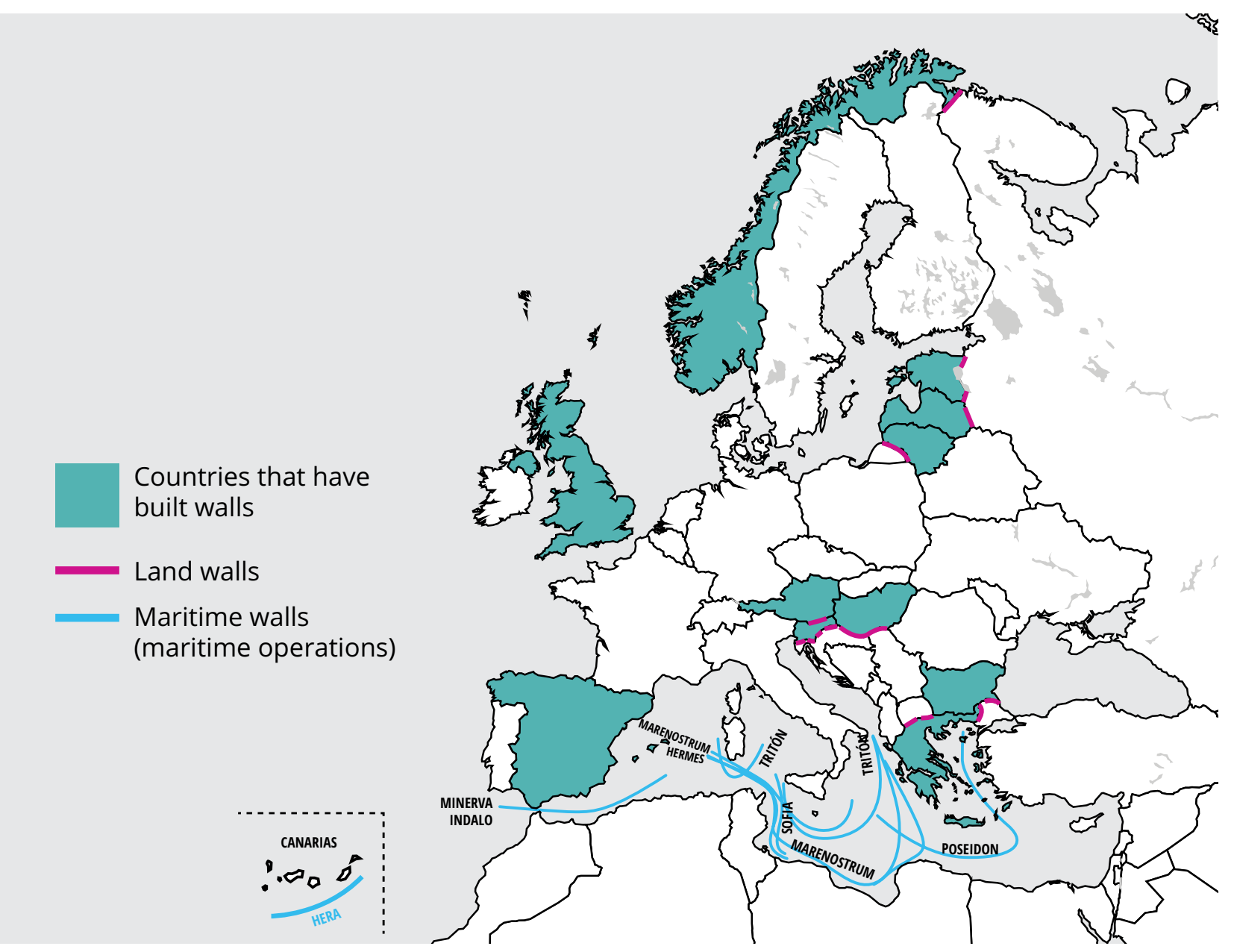

Walls of the countries of European Union Member States, Schengen area and Macedonia (1990-2017)*

\begin{tabular}{|l|l|l|l|}
\hline BUILDING COUNTRY & COUNTRY AGAINST WHICH IT IS MADE & STARTING YEAR & REASONS \\
\hline Spain (1) & Morocco (Ceuta) & 1993 & Immigration \\
\hline Spain (2) & Morocco (Melilla) & 1996 & Immigration \\
\hline Greece (3) & Turkey & 2012 & Immigration \\
\hline Slovakia (4) & Internal cities: Kosice, Velka Ida, Ostrovany & $2013-$ under construction & Segregation, security \\
\hline Bulgaria (5) & Turkey & 2013 & Immigration \\
\hline Hungary (6) & Croatia & 2015 & Immigration \\
\hline Hungary (7) & Serbia & 2015 & Immigration \\
\hline Macedonia (8) & Greece & 2015 & Immigration \\
\hline Austria (9) & Slovenia & 2015 & Immigration \\
\hline Slovenia (10) & Croatia & 2015 & Immigration \\
\hline United Kingdom (11) & France (port of Calais) & 2015 & Immigration \\
\hline Latvia (12) & Russia & 2015 & $\begin{array}{l}\text { Security, territorial tension, smuggling, } \\
\text { immigration }\end{array}$ \\
\hline Norway (13) & Russia & 2016 & Security, immigration \\
\hline Estonia (14) & Russia & $2016-2017$ & Security, territorial tension, immigration \\
\hline Lithuania & Russia & 2017 & Security, territorial tension, immigration \\
\hline
\end{tabular}




\section{EUROPE'S MANY KINDS OF WALLS}

This report complements Building Walls: Fear and securitization in the European Union, published in September 2018. It investigates the costs of and companies involved in developing the walls the report describes.
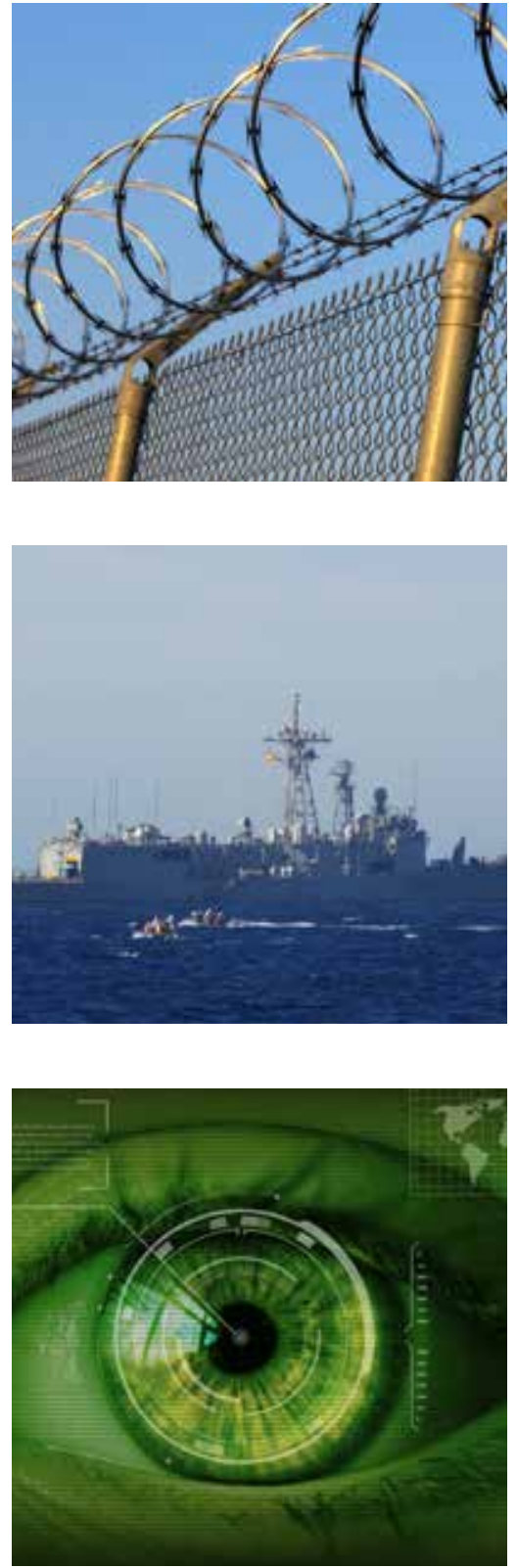

LAND WALLS: Walls built by EU members and the Schengen Area with the addition of the Macedonian wall as a key country in the Balkan route. Fences and walls on Cyprus and in Northern Ireland were excluded because they were built before the period of analysis (1990-2017). ${ }^{17}$ Several walls included in Building Walls, namely those in Slovakia, mostly aimed at segregating the Roma population, were excluded because they are not at the borders or meant for antiimmigration purposes and were usually built by local authorities or were private initiatives. ${ }^{18}$

MARITIME WALLS: These are the main maritime operations carried out to control migratory flows in the Mediterranean area and include Frontex operations (Hera, Hermes, Indalo, Minerva, Poseidon, Triton), the EU military operation Operation Sophia (also known as EUNAVFOR MED) and the Italian Mare Nostrum. ${ }^{19}$ The new Frontex Operation Themis, which replaced Triton in February 2018, has been added to this report. ${ }^{20}$

VIRTUAL WALLS: These are the systems developed by the EU to control and monitor the movement of people and include Eurodac, VIS (Visa Information System), SIS II (Schengen Information System), EES (Entry/Exit Scheme), ETIAS (European Travel Information and Authorisation System). ${ }^{21}$ The RTP (Registered Traveller Programme), abandoned by the European Commission in 2016, and non-EUsystems SLTD (Stolen Lost Travel Documents) and I-Checkit system, both run by Interpol, are not addressed. 


\section{NOTES ON METHODOLOGY}

Costs: Estimated costs for the different types of wall come from various sources. Where possible, this report used official EU or member states' government documents, preferably annual budgets or accounts. For most maritime and virtual walls these were available, or EU institutions referred to the costs in other documents. The construction costs for land walls are mostly met by national governments and the estimated costs come from mainly media sources, based on statements by governments or government spokespersons. This means it is often not clear what is covered by these estimated costs. Do these include only materials or contracts with companies? Do they cover personnel costs? Do they concern only the fence or wall as such, or do they also include accompanying technology and other additional costs? Such unanswered questions make it difficult to compare the estimated costs of land walls.

Companies: The report aims to identify the most important companies involved in the various types of wall and assess this at different scales. For this it looks at:

Land walls: companies contracted to build the fences and walls, companies providing accompanying technology, equipment and services. Scale: National contracts

Maritime walls: companies that provided the major assets (ships, aircraft, helicopters, drones) used in maritime operations. Scale: Member State contracts and assets

Virtual walls: companies contracted to develop, run, expand and maintain the systems. Scale: EU-level contracts 


\section{COSTS AND FUNDING OF EUROPE'S WALLS}

European spending on border security and control has skyrocketed, particularly since the 2015 'refugee crisis'. Both the EU and its member states have increasingly invested in a wide range of measures within and beyond Europe, buying equipment and services, deploying more personnel and supporting research and innovation (R\&l) to develop new technologies.

For the next EU budget cycle, the Multiannual Financial Framework 2021-2027, in 2018 the European Commission proposed to triple expenditure on migration and border management, to $€ 34.9$ billion. ${ }^{22}$ While the proposal is still under negotiation, most of the proposed spending has already been approved by the European Parliament and the Council.

These plans include a major increase in funding for the institutions responsible for the maritime and virtual walls: the border security agency Frontex and eu-LISA, the agency that manages large-scale IT systems. There will also be more funding for member states, through the new €8 billion Integrated Border Management Fund. ${ }^{23}$ Member states are expected to spend part of this on strengthening these walls, purchasing equipment to be made available to Frontex, strengthening national points for the EU-wide surveillance system Eurosur and integrating identity database systems. ${ }^{24}$ Member states are not allowed, however, to use EU finance to build physical land walls. Since the EU publicly opposes land walls (see discussion below), building them is the responsibility of the individual member states.

The total cost for the land, maritime and virtual walls built by the EU and its member states runs into billions of euros. EU spending on the main maritime and virtual walls was over $€ 2$ billion from 2000 to 2019. Annual costs keep increasing, mainly because of the introduction of new technological systems and the expansion of Frontex. Based on available information a conservative estimate of EU member state spending on land walls and fences is $€ 1$ billion, but actual costs may be much higher. 


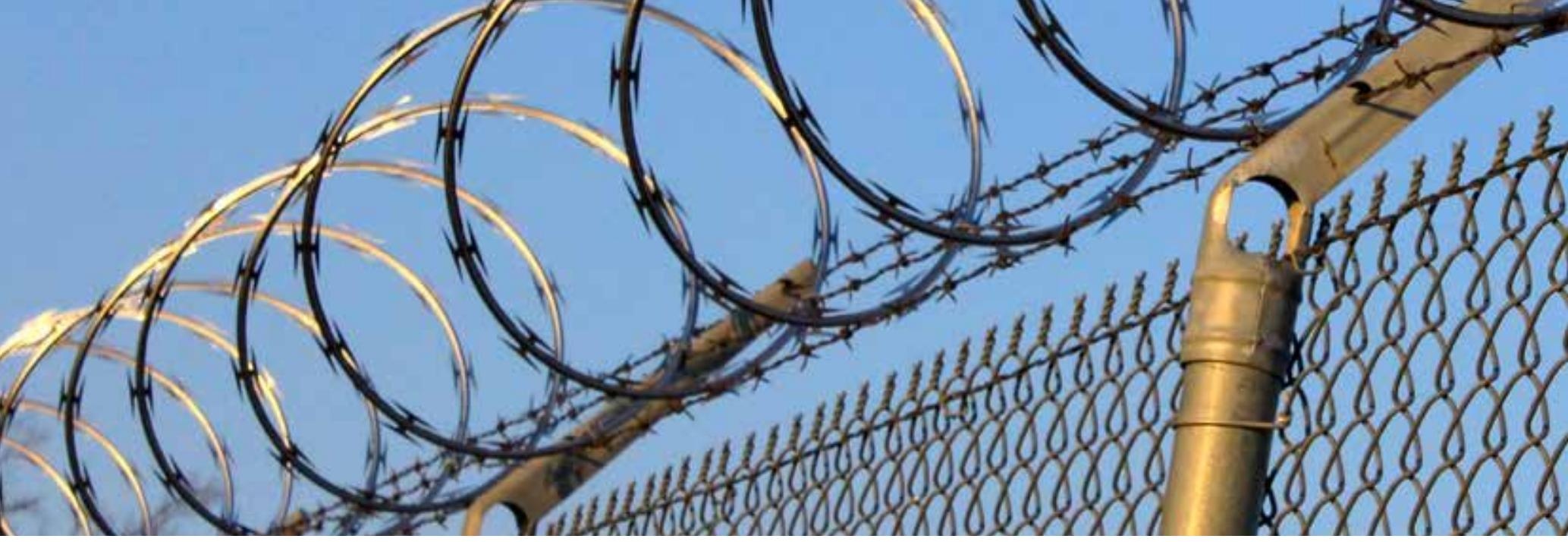

\section{LAND WALLS}

It is hard to get a good overview of the costs of the walls and fences. Not all governments publish figures, while those that are published or given to the European Parliament or media seldom include a breakdown of specific costs. In some instances, the estimated spending comprises only the cost of the fence itself, while others include additional costs including accompanying technology, personnel and maintenance.

In April 2016, based on an analysis of public data, Reuters estimated that European countries had spent at least $€ 500$ million on anti-immigrant walls and fences since the end of the Cold War. ${ }^{25}$ Many of those now on European borders had not yet been built in 2016. Adding up figures available in 2019 shows that now over $€ 900$ million has been spent on walls and fences. Because these figures are incomplete (in scope and/or years), actual costs, including maintenance and upgrades, will be at least $€ 1$ billion, if not more.

\section{Estimation of costs of European border walls}

\begin{tabular}{|l|l|l|l|}
\hline BUILDING COUNTRY & $\begin{array}{l}\text { COUNTRY AGAINST WHICH } \\
\text { IT IS BUILT }\end{array}$ & $\begin{array}{l}\text { ESTIMATE OF COSTS } \\
\text { (MILLION } € \text { ) }\end{array}$ & REMARKS \\
\hline Spain & Morocco (Ceuta) & 95.9326 & For first fence (1995-2000), installation new fence and maintenance (2005-2013) \\
\hline Spain & Morocco (Mellila) & 36.6727 & For first fence (1998), installation new fence and maintenance (2005-2013) \\
\hline Greece & Turkey & 7.5028 & Of which €3.16 million for a private company building the wall \\
\hline Bulgaria & Turkey & 87.3529 & \\
\hline Hungary & Croatia & \multirow{2}{*}{440.0030} & \\
& Serbia & & \\
\hline Mangary & Greece & No information found \\
\hline Austria & Slovenia & $8.00-10.0031$ & Initially leased, later purchased \\
\hline Slovenia & Croatia & 80.0032 & \\
\hline United Kingdom & France (Port of Calais) & 2.7033 & Not including other fences at several points in and around Calais \\
\hline Latvia & Russia & 21.1734 & Including wooden footbridges, patrol paths, culverts and a footprint strip \\
\hline Norway & Russia & 0.4435 & \\
\hline Estonia & Russia & 130.536 & \\
\hline Lithuania & Russia & 30.0037 & Estimation before start of project \\
\hline TOTAL & & $\mathbf{9 4 0 . 2 6}$ & \\
\hline
\end{tabular}

In general, individual EU member states have paid for these walls and fences. The European Commission has been outspoken against erecting physical walls and fences at the EU's external borders and refuses to fund them, contrary to many other forms of border security and control. In response to Hungary's request to reimburse half of the costs of the fences built on the borders with Croatia and Serbia, Commission spokesperson Alexander Winterstein said: 'We do support border management measures at external borders. These can be surveillance measures. They can be border control equipment... But fences, we do not finance'. ${ }^{38}$ The Commission again ruled out funding walls and fences in the next budget cycle (2021-2027). ${ }^{39}$ 
The EU position on land walls at first glance seems to be a shift since before 2015 , when the Commission would fund border fences. Before 2000 it financed $75 \%$ of the costs of fences around Ceuta, an estimated $€ 48$ million, with movement detectors, video- and infrared-cameras and 17 control towers. ${ }^{40}$ When the European Commission granted Spain $€ 10$ million in emergency funding to boost border security at its enclaves in Morocco, the Spanish government announced that some of this would be partly used to strengthen existing border fences. ${ }^{41}$

Dimitris Avramopoulos, European Commissioner for Migration, explained on several occasions that fences are 'not a solution' and will not work. ${ }^{42}$ In May 2018, Avramopoulos said that the Commission would not support a new wall or fence between Greece and Turkey. ${ }^{43}$ It is noteworthy, however, that in his former capacity as Greek Minister of Defence Avramopoulos built one of the first border walls in Europe to stop migration, along the border with Turkey. ${ }^{44}$

When the Greek government at the time asked for EU funding, European Commissioner Cecilia Malmström said 'the construction of a fence will not provide in itself a solution to irregular migration. It is likely that the migratory pressure will be deviated to other sections of the external land or sea borders of Greece or to other Member States'. ${ }^{45}$ This insight did not prevail: current EU migration policies are predominantly aimed at boosting border security, resulting in shifting migration routes and forcing migrants and refugees to use more dangerous ones.

But given that EU funding is still available for almost everything but the physical fences and walls, the Commission's aversion to walls now looks like a bit of a charade. As April Humble, Steve Wright and Ben Hayes point out, a wall is more than a wall: 'The border-exclusion technologies deployed against unauthorised migrants include concrete walls, virtual walls, monitoring and sniper towers, cameras, land radars and wireless telecommunication infrared surveillance, carbon-dioxide probes, information technology, identification systems and immigration databases'. ${ }^{46}$

For example, in Ceuta and Melilla, the EU funded 'CCTV camera-equipment' in Ceuta and 'a watchtower in Melilla', (€164,000 in 2010), 'police offices to manage procedures related to the irregular influx of migrants' (€448,000 in 2012) and reinforcement of 'State security forces in Ceuta and Melilla' (almost €4 million in 2012). ${ }^{47}$ When in 2019, the Spanish government promised to remove the concertinas (razor wire) on the fences around both enclaves, the Moroccan government started installing its own. This was part of its own border-security efforts, for which the EU donated €140 million from the Emergency Trust Fund for Africa (EUTF) in December $2018 .{ }^{48}$ Spain contributed a further $€ 60$ million to this sum in the summer of $2019 .{ }^{49}$

The patrol cars from Turkish arms company Otokar, which surveille the wall between Turkey and Syria, are also funded with €35.6 million EU money. ${ }^{50}$

In other words EU-funded purchases and measures clearly fortify Europe's walls, regardless of whether they are spent on fencing or concrete.

All this suggests that the Commission's current stance is mostly about maintaining an image, motivated by its concern to avoid presenting Europe as a physically closed off part of the world.

Where the European Commission is more consistent is in opposing borders between EU member states. The Commission adheres strongly to upholding 'free movement' within the Schengen Area and has therefore opposed any long-term reintroduction of border controls between Schengen countries. When Austria indicated that it wanted to build a wall on the border with Italy, an EU member state, the Commission stated that it was 'very concerned'. ${ }^{51}$ 


\section{MARITIME WALLS}

Most of the maritime operations to stop migration to Europe are coordinated by the EU border security agency Frontex (also known as the European Border and Coast Guard Agency). Its own operational costs are limited since member states provide most personnel as well as large assets, such as ships and helicopters. Frontex has a Technical Equipment Pool of equipment owned by member states and/or by Frontex. Operation Sophia also comprises assets and personnel provided by participating member states, while Mare Nostrum was almost completely paid for by Italy.

Although they fall largely outside the scope of this report, EU member states also have their own maritime walls. These include general surveillance operations by Mediterranean countries including Italy, Greece and Spain, but also the increasing use of UK vessels to patrol the English Channel.

\section{FRONTEX OPERATIONAL COSTS}

Frontex does not publish the costs of individual operations. Its annual accounts provide a total figure of commitments for the budget item 'operations and projects, sea borders', which shows a rapid increase from 2015 on. From 2006 to 2017, Frontex committed a total €534 million to its sea operations. From 2018 , its total operational costs (sea, land, air) were pooled into one budget item with a total spending of $€ 116.6$ million. ${ }^{52}$ The vast majority of this will have been spent on maritime operations. The same applies to the $€ 119.6$ million dedicated to 'Operational response' in its 2019 budget. $^{53}$

\section{Frontex - spending on sea operations (2006-2017) $)^{54}$}

\begin{tabular}{|l|l|l|r|}
\hline YEAR & SPENDING (MILLION €) & YEAR & SPENDING (MILLION €) \\
\hline 2006 & 8.8 & 2012 & 25.0 \\
\hline 2007 & 16.7 & 2013 & 28.9 \\
\hline 2008 & 28.7 & 2014 & 28.2 \\
\hline 2009 & 2015 & 70.4 \\
\hline 2010 & 2016 & 107.8 \\
\hline 2011 & 29.4 & 2017 & 108.3 \\
\hline TOTAL & 48.3 & $\mathbf{5 3 4 . 9}$ \\
\hline
\end{tabular}




\section{OPERATION MARE NOSTRUM}

Italy spent about $€ 114$ million on Mare Nostrum, its own year-long maritime border-security mission (October 2013-October 2014), which was replaced by the Frontex-led Operation Triton. ${ }^{55}$ The EU contributed $€ 1.8$ million from the External Borders Fund emergency actions budget. ${ }^{56}$ The External Borders Fund, managed by the European Commission, was used to strengthen member states' border security.

\section{OPERATION SOPHIA}

Operation Sophia, which does not fall under Frontex, has its own budget. Again, the large assets and personnel for the operation are provided by EU member states, 'with the running costs and personnel costs [also] being met on a national basis'. ${ }^{57}$ The EU budget for Operation Sophia is provided through 'Athena', an off-budget mechanism to finance the common costs of EU military operations. It was set up by the Council of the European Union, and remains outside the official EU budget because official EU money can't be used for military operational costs.

\section{EU budget for Operation Sophia}

\begin{tabular}{|l|r|}
\hline PERIOD & BUDGET (MILLION €) \\
\hline 22 June 2015 - 27 July 2016 & $11.8^{58}$ \\
\hline 28 July 2016-27 July 2017 & $6.7^{59}$ \\
\hline 27 July 2017 - 31 December 2018 & $6.0^{60}$ \\
\hline 1 January 2019-31 March 2019 & $1.1^{61}$ \\
\hline 1 April 2019 - 30 September 2019 & $2.8^{62}$ \\
\hline TOTAL & $\mathbf{2 8 . 4}$ \\
\hline
\end{tabular}

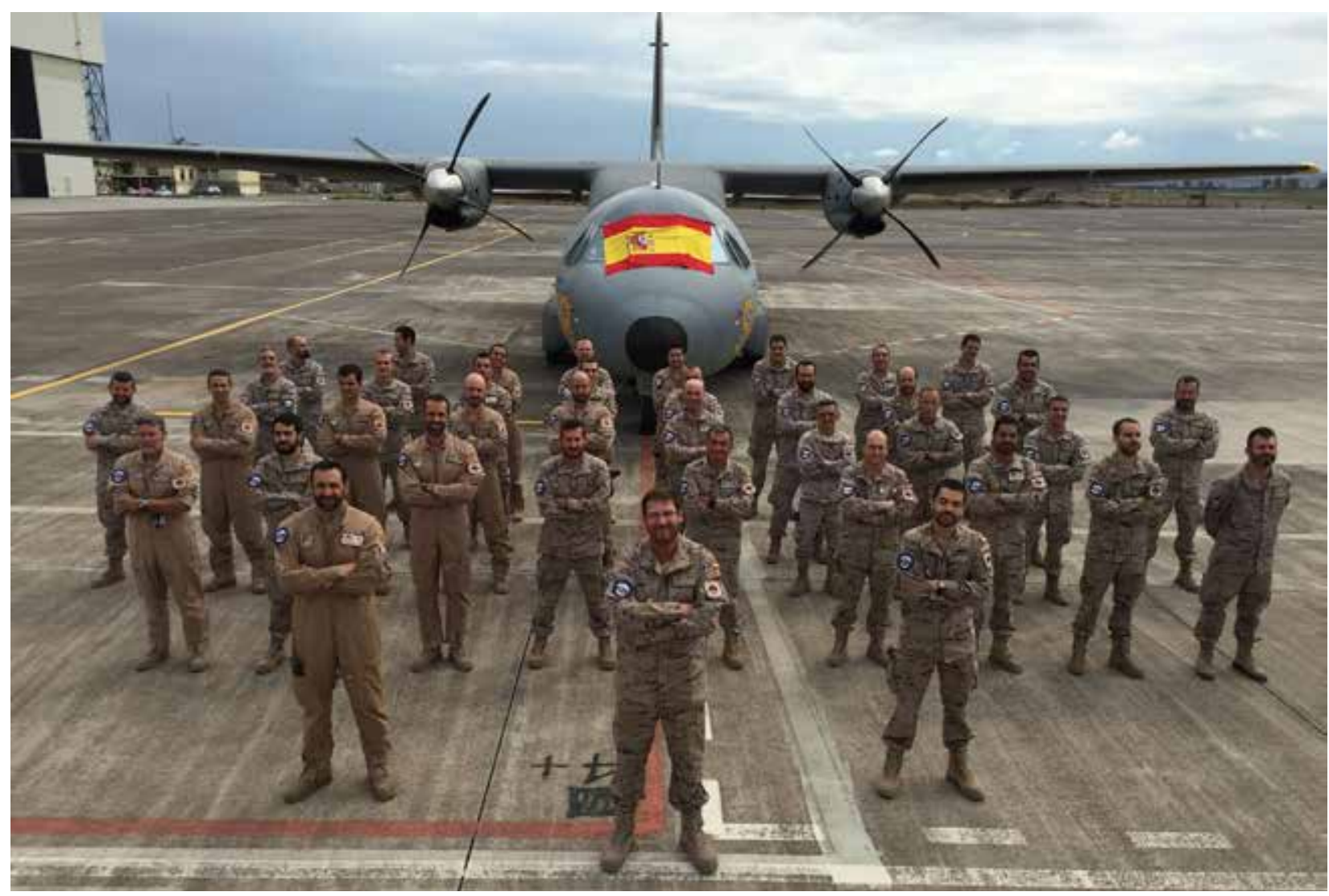

Spanish military team in Grappa for Operation Sophia. Credit: Ministerio de Defensa 


\section{FUTURE SPENDING}

Frontex has long expressed concerns that member states fail to meet their promises to make personnel and equipment available for joint operations. In 2015, the European Commission, the Council and the European Parliament granted Frontex an extensive expansion of powers, personnel and budget, which enabled it to buy or lease equipment for operations. Under its budget for the next EU budget cycle (2021-2027) the European Commission has earmarked $€ 2.2$ billion for acquiring, maintaining and operating air, sea and land assets. ${ }^{63}$

The new European Commission President, Ursula von der Leyen, has given priority to speeding up Frontex expansion. At the start of her tenure in September 2019 she said: 'We need to address the legitimate concerns of many and look at how we can overcome our differences. I will propose a New Pact on Migration and Asylum, including the relaunch of the Dublin reform. This will allow us to return to a fully functioning Schengen Area of free movement, the key driver of our prosperity, security and freedoms. A centrepiece in this ambition is a reinforced European Border and Coast Guard Agency. We need to reach a standing corps of 10,000 Frontex border guards not by 2027 , but way earlier, at least by $2024^{\prime}{ }^{64}$

Since the Commission's approval of a Frontex budget for its own technical equipment, Frontex has opted to lease when possible, buying when necessary. The preference for leasing is connected to 'leaving the through-life management responsibilities with the supplier'. However, for complex systems and bespoke equipment, Frontex sees ownership as the best option, which could also apply when leasing leads to 'unwanted non-EU supply chain dependencies', signalling a preference for buying or leasing from European industries. ${ }^{65}$

Its procurement plans for 2018 and 2019 give some insight into Frontex's new equipment strategy. Along with other planned purchases, ranging from deportation flights to office maintenance, it outlines a shopping list for operational equipment. This includes vehicles for migration management support (estimated contract value: $€ 2$ million), leased maritime capability (pilot project, €2.5 million), mobile surveillance services (€28 million) and chartering a Coastal Patrol Vessel for border surveillance and control (€10 million). ${ }^{66}$

New Frontex regulations in 2015 also allow Frontex to buy equipment in co-ownership with member states. Whether Frontex owns the equipment alone or jointly, it has to be registered in a member state while being available for Frontex. This co-ownership has not been without problems, with one assessment concluding 'that it is very complex and therefore requires more in-depth legal analysis before an exploitation route can be developed'. ${ }^{67}$

The Internal Security Fund - Borders and Visa, the main EU funding instrument for boosting border security of member states - provides another means for them to finance equipment purchases for Frontex. Member states can use these acquisitions for their own border security, but must register them in the Frontex Technical Equipment Pool and make them available to Frontex upon request. ${ }^{68}$ The Rapid Reaction Equipment Pool, made up of assets that should be available no more than ten days after approval of a planned Frontex operation, is part of this pool. ${ }^{69}$ 


\section{Composition of Frontex Technical Equipment Pool (December 2018) - Heavy equipment ${ }^{70}$}

\begin{tabular}{|c|c|c|c|c|c|c|c|c|c|}
\hline MEMBER STATE & $\begin{array}{l}\text { FIXED-WING } \\
\text { AIRCRAFT }\end{array}$ & HELICOPTERS & $\begin{array}{l}\text { PATROL VESSELS } \\
\text { / BOATS }\end{array}$ & TOTAL & MEMBER STATE & $\begin{array}{l}\text { FIXED-WING } \\
\text { AIRCRAFT }\end{array}$ & HELICOPTERS & $\begin{array}{l}\text { PATROL VESSELS } \\
\text { / BOATS }\end{array}$ & TOTAL \\
\hline Austria & & 1 & & 1 & Lithuania & & 3 & 1 & 4 \\
\hline Bulgaria & & & 1 & 1 & Luxembourg & 1 & & & 1 \\
\hline Croatia & & & 6 & 6 & Malta & 3 & & 11 & 14 \\
\hline Cyprus & & 1 & 1 & 2 & Netherlands & 2 & & 2 & 4 \\
\hline Estonia & 1 & & 1 & 2 & Norway & & & 3 & 3 \\
\hline Finland & 1 & & 3 & 4 & Poland & 2 & 2 & 1 & 5 \\
\hline France & 2 & 2 & 5 & 9 & Portugal & 2 & 1 & 95 & 98 \\
\hline Germany & & 3 & 3 & 6 & Romania & & 1 & 4 & 5 \\
\hline Greece & 2 & 1 & 82 & 85 & Slovakia & 1 & & & 1 \\
\hline Iceland & 1 & 1 & 1 & 3 & Slovenia & & 4 & & 4 \\
\hline Italy & 12 & 26 & 140 & 178 & Spain & 1 & 1 & & 2 \\
\hline Latvia & & 2 & 4 & 6 & Sweden & & & 1 & 1 \\
\hline & $+1+5+1+5$ & & 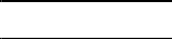 & $\mathrm{C}_{\mathrm{C}}$ & Total & 32 & 48 & 365 & 445 \\
\hline \multicolumn{9}{|c|}{ Belgium, Czech Republic, Denmark, Hungary, Switzerland, United Kingdom } & 0 \\
\hline
\end{tabular}

In September 2017, the Frontex Management Board wrote that on purchases under the Internal Security Fund there is 'little progress to report as many of the acquisition projects are still ongoing and procurement activities have yet to be initiated by Member States'. ${ }^{71}$ In 2017, only one tender was released, followed by two in 2019, involving Greece, Poland and Romania.

\section{Frontex and EU member states' tenders/contracts for assets for use in Frontex border security operations (2017-2019)}

\begin{tabular}{|c|c|c|c|c|}
\hline \multicolumn{5}{|c|}{ Frontex } \\
\hline YEAR & PURCHASE / LEASE & \multicolumn{2}{|l|}{ DESCRIPTION } & VALUE (MILLION $€$ ) \\
\hline 2017 & Lease & \multicolumn{2}{|c|}{ Trial of long endurance maritime surveillance with MALE Remote Piloted Aircraft Systems (RPAS) ${ }^{72}$} & 6.4 \\
\hline 2018 & Lease & \multicolumn{2}{|l|}{ Lease of one surveillance aerostat to carry out a pilot project in Greece ${ }^{73}$} & 0.5 \\
\hline 2018 & Lease & \multicolumn{2}{|c|}{ Framework contract for leasing of off-road vehicles for Frontex operational activities ${ }^{74}$} & 1.0 \\
\hline 2019 & Lease & \multicolumn{2}{|c|}{$\begin{array}{l}\text { Framework contract for provision of mobile surveillance systems for Frontex operational } \\
\text { activities }^{75}\end{array}$} & 28.0 \\
\hline 2019 & Lease & \multicolumn{2}{|c|}{ Maritime surveillance aerostat trial ${ }^{76}$} & 0.5 \\
\hline 2019 & Lease & \multicolumn{2}{|l|}{ Aerial surveillance services for border and coast guard functions ${ }^{77}$} & 29.0 \\
\hline 2019 & Lease & \multicolumn{2}{|c|}{$\begin{array}{l}\text { Remotely Piloted Aircraft Systems (RPAS) for medium altitude long endurance maritime aerial } \\
\text { surveillance }^{78}\end{array}$} & 50.0 \\
\hline 2019 & Purchase & \multicolumn{2}{|c|}{ Framework contract for provision of vehicles for migration management support ${ }^{79}$} & 2.0 \\
\hline \multicolumn{5}{|c|}{ Member states } \\
\hline YEAR & MEMBER STATE & DESCRIPTION & EU FUNDING & VALUE (MILLION $€$ ) \\
\hline 2017 & Poland & Purchase of two multi-engines for surveillance tasks & ISF-Borders & $?$ \\
\hline 2017 & Portugal & $\begin{array}{l}\text { Demonstrating state-of-the-art RPAS systems services in support of } \\
\text { Frontex, EMSA and EFCA }{ }^{80}\end{array}$ & - & 0.3 \\
\hline 2018 & Latvia & Purchase of three patrol vessels ${ }^{81}$ & -82 & 2.0 \\
\hline 2018 & Denmark $^{83}$ & $\begin{array}{l}\text { Supplement of contract to use one of two leased aircraft for border } \\
\text { surveillance for Frontex operations }\end{array}$ & - & $0.1^{84}$ \\
\hline 2019 & Romania & Supply of one maritime patrol vessel and three intervention vessels ${ }^{85}$ & ISF-Borders & $34.8^{86}$ \\
\hline 2019 & Greece & Supply of three coastal patrol vessels ${ }^{87}$ & ISF-Borders & 41.7 \\
\hline 2019 & Slovenia & Motor vehicles 88 & ISF-Borders & 3.0 \\
\hline
\end{tabular}




\section{VIRTUAL WALLS}

EU spending on virtual walls has rapidly escalated since 2017, with the introduction of new systems such as the Entry/Exit System (EES) and increased spending on EURODAC and SIS II. EES tracks non-EU nationals across Europe using a central database and is expected to become fully operational in 2020, while EURODAC is a fingerprint database specifically for asylum-seekers and irregular border crossers that has been in existence since 2003. SIS II is the latest iteration of the Schengen Information System (SIS), an information-sharing system for security and border authorities across Europe which integrates increasing amounts of biometric data such as fingerprints and facial images as well information on return decisions or entry bans for migrants.

For the EES, expenditure to date - $€ 256.3$ million - is only a part of the predicted total of $€ 480$ million. ${ }^{89}$ Likewise, developing the European Travel Information and Authorisation System (ETIAS) is expected to cost $€ 212.1$ million, with average annual operations $€ 85$ million even though current spending stands at only $€ 34.5$ million. ${ }^{90}$ These projections mean a conservative estimate of $€ 1.9$ billion are being spent on the identity databases and surveillance system Eurosur.

\section{EU spending on systems for the control and storage of data on movements across borders (million $€$ )}

\begin{tabular}{|c|c|c|c|c|c|c|}
\hline YEAR & EURODAC & VIS & SIS II92 & EES & ETIAS & TOTAL \\
\hline 2000 & \multirow{4}{*}{$7.5^{93}$} & & \multirow{13}{*}{$167.8^{94}$} & & & \multirow{13}{*}{384.6} \\
\hline 2001 & & & & & & \\
\hline 2002 & & & & & & \\
\hline \multicolumn{2}{|l|}{2003} & & & & & \\
\hline 2004 & $0.3^{95}$ & \multirow{2}{*}{$30.0^{96}$} & & & & \\
\hline 2005 & $0.1^{97}$ & & & & & \\
\hline 2006 & $0.2^{98}$ & $18.7^{99}$ & & & & \\
\hline 2007 & $0.8^{100}$ & $20.0^{101}$ & & & & \\
\hline 2008 & $0.6^{102}$ & $16.5^{103}$ & & & & \\
\hline 2009 & $1.2^{104}$ & $28.6^{105}$ & & & & \\
\hline 2010 & $2.1^{106}$ & $19.1^{107}$ & & & & \\
\hline 2011 & $1.0^{108}$ & $29.7^{109}$ & & & & \\
\hline 2012 & $0.4^{110}$ & $40.0^{111}$ & & & & \\
\hline 2013 & 6.9 & 8.8 & 30.0 & & & 45.7 \\
\hline 2014 & 0.5 & 21.1 & - & & & 21.6 \\
\hline 2015 & 5.6 & 24.2 & 2.2 & & & 32.0 \\
\hline 2016 & 1.3 & 31.2 & 12.8 & & & 45.3 \\
\hline 2017 & 18.6 & 35.2 & 6.5 & 54.5 & & 114.8 \\
\hline 2018 & 15.1 & 19.7 & 31.8 & 57.5 & 23.5 & 147.6 \\
\hline 2019 & 8.6 & 23.7 & 20.2 & 144.3 & $11.8^{112}$ & 207.8 \\
\hline Total & 70.8 & 366.5 & 271.3 & 256.3 & 34.5 & 999.4 \\
\hline
\end{tabular}


In May 2019, after prior agreement by the European Parliament, the Council of the EU adopted regulations to enable inter-operability between various information systems, including the databases mentioned above, to 'improve security, allow for more efficient checks at external borders and contribute to prevent and combat illegal migration'. This would lead to a European search portal and a shared biometric matching service, which would allow the EU and member states simultaneously to search multiple databases and cross-check identities with biometric data. ${ }^{113}$ The cost of connecting the databases is estimated to be at least $€ 425$ million over nine years, of which $€ 225$ million would go to eu-LISA and $€ 136$ million to member states for updating systems and training users. ${ }^{114}$

According to a European Commission official, the whole decision-making process was rushed, saying that: 'I don't think anyone understands what they're voting for'. A Parliament official mentioned that there was much lobbying behind the scenes. ${ }^{115}$ The EU Supervisor for Data Protection, Giovanni Buttarelli, criticised the proposal, because of privacy considerations and the fear that a centralised system would be vulnerable to cyber attacks. ${ }^{116}$ Tony Bunyan at Statewatch questioned the reasoning: 'The Commission's proposal for interoperable centralised EU databases is justified on the threat posed to internal security by migration and terrorism. This conflation of threats based on fear of the "other" is a classic case of state racism'. ${ }^{117}$

\section{EUROSUR}

The European Commission's 2011-2020 estimates for Eurosur, the 'system of surveillance systems' amount to $€ 338$ million. ${ }^{118}$ It is unclear whether this includes all the member states' own efforts to upgrade their border surveillance systems and integrate them in Eurosur - many of which also receive support from the External Borders Fund and its successors, the Internal Security Fund - Borders (ISF) and the upcoming Integrated Border Management Fund (IBMF).

The regulation for the International Security Fund explicitly states that "Member States shall devote the necessary funding to Eurosur in order to ensure its good functioning." ${ }^{119}$ A minimum of $10 \%$ of the grants under the ISF was set as a threshold, from which member states could deviate with good reasons, which the European Commission proposes to continue for the IBMF. ${ }^{120}$

The spending by member states on Eurosur from 2013 to 2017 was estimated at around 75 million euros. ${ }^{121}$ If the EU holds onto the $10 \%$ threshold for spending on Eurosur under the IBMF, this would mean at least another 425 million euros by member states for the period 2021-2027, which seems to be extraordinary given the EU's own estimates on required spending on Eurosur.

The development of Eurosur is also supported by EU investment in research R\&I under the so-called Framework Programmes. Through Horizon2020 (2014-2020) and its predecessor, Framework Programme 7 (2007-2013), the EU has funded research projects in the field of border security worth millions of euros, including many which were (partly) aimed at developing and improving Eurosur. ${ }^{122}$ 


\section{OVERVIEW}

\section{FINANCING THE BORDER WALLS}

\section{LAND WALLS}

\begin{tabular}{|l|l|l|}
\hline & EU LEVEL & MEMBER STATE LEVEL \\
\hline Construction & & National budgets \\
\hline \multirow{2}{*}{$\begin{array}{l}\text { Accompanying } \\
\text { technology }\end{array}$} & External Borders Fund & \multirow{2}{*}{ National budgets } \\
\cline { 2 - 2 } & Internal Security Fund - Borders & \\
\cline { 2 - 2 } & Integrated Border Management Fund & \\
\hline
\end{tabular}

\section{MARITIME WALLS}

\begin{tabular}{|l|l|l|}
\hline \multirow{4}{*}{ Frontex operations } & EU LEVEL & MEMBER STATE LEVEL \\
\cline { 2 - 2 } & Frontex budgets & \multirow{2}{*}{ National contributions to Frontex } \\
\cline { 2 - 2 } & External Borders Fund & \\
\cline { 2 - 2 } & Internal Security Fund - Borders & \\
\cline { 2 - 2 } & Integrated Border Management Fund & \\
\cline { 2 - 2 } & European Maritime Safety Agency & \\
\hline Operation Sophia & Athena & National contributions \\
\hline $\begin{array}{l}\text { Operation Mare } \\
\text { Nostrum }\end{array}$ & External Borders Fund & National contribution Italy \\
\hline
\end{tabular}


VIRTUAL WALLS

\begin{tabular}{|l|l|l|}
\hline & EU LEVEL & MEMBER STATE LEVEL \\
\hline \multirow{3}{*}{$\begin{array}{l}\text { Eurodac, VIS, SIS II, } \\
\text { EES, ETIAS }\end{array}$} & Eu-LISA & \multirow{3}{*}{ National budgets } \\
\cline { 2 - 2 } & External Borders Fund & \\
\cline { 2 - 2 } & Internal Security Fund - Borders & \\
\cline { 2 - 2 } & Integrated Border Management Fund & \\
\hline
\end{tabular}

RESEARCH \& INNOVATION

\begin{tabular}{|l|l|l|}
\hline & EU LEVEL & MEMBER STATE LEVEL \\
\hline & European Commission & National \\
\cline { 2 - 3 } & $\begin{array}{l}\text { Framework Programmes - FP7, } \\
\text { Horizon 2020 and Horizon Europe }\end{array}$ & \\
\hline
\end{tabular}

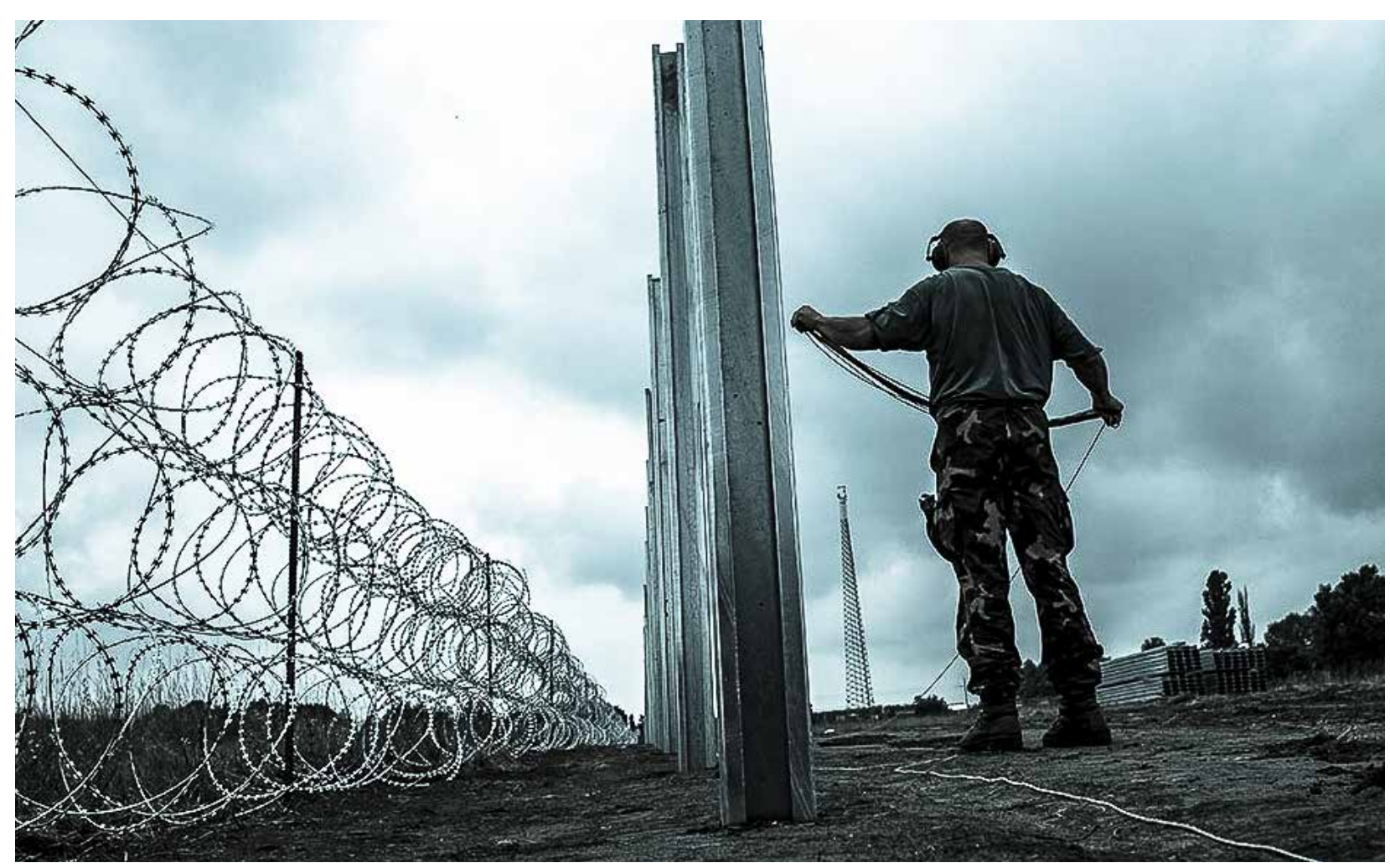

Members of the Hungarian Defence Force install barbed wire on the Hungarian-Serbian border to prevent illegal migrants from entering the country near Kelebia village in Hungary on August 17, 2015. Credit @syriafreedom/Flickr 


\section{EU BUDGETS FOR BORDER}

in $€$ billions of Euros

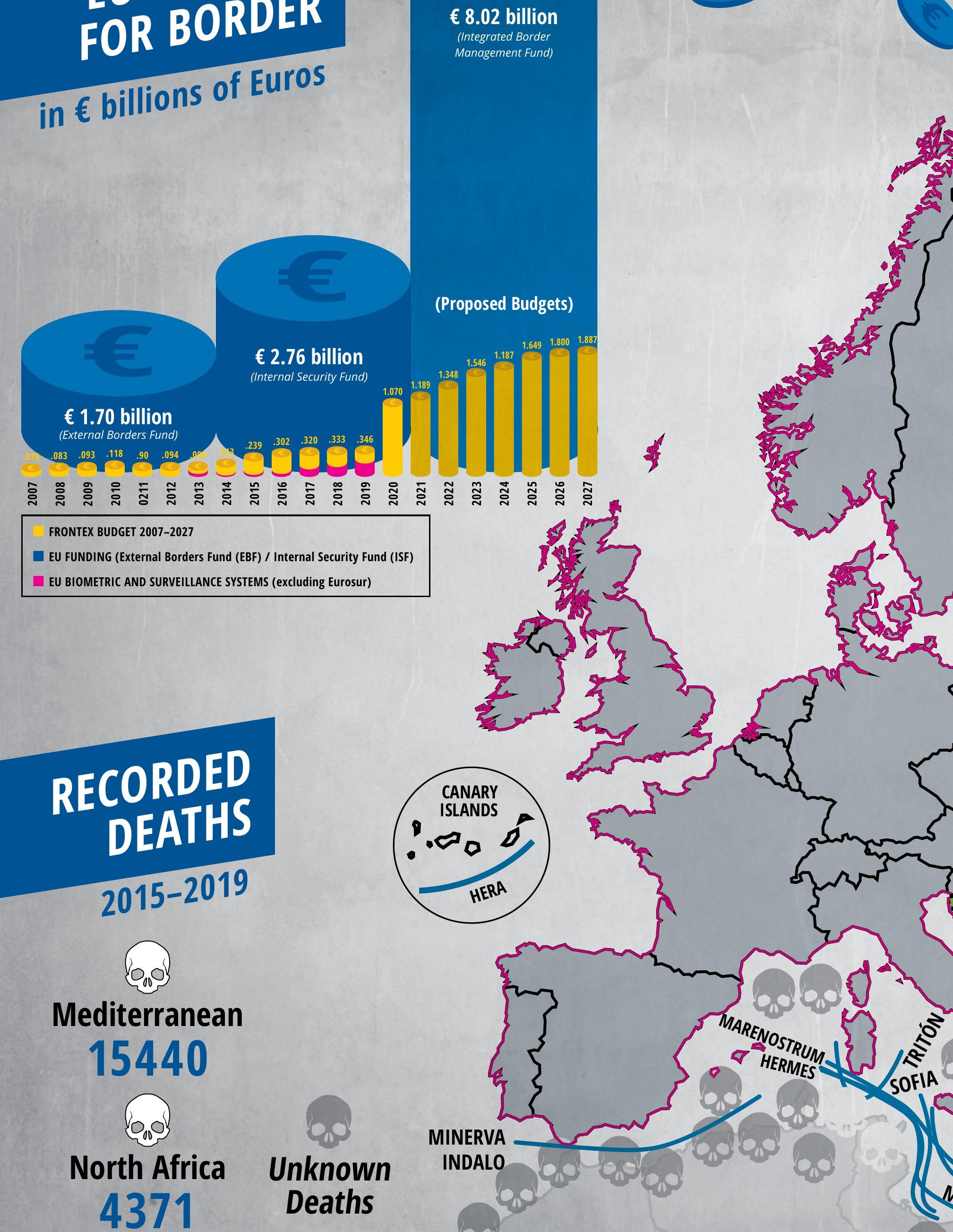

$€ 8.02$ billion

(Integrated Border

Management Fund) 


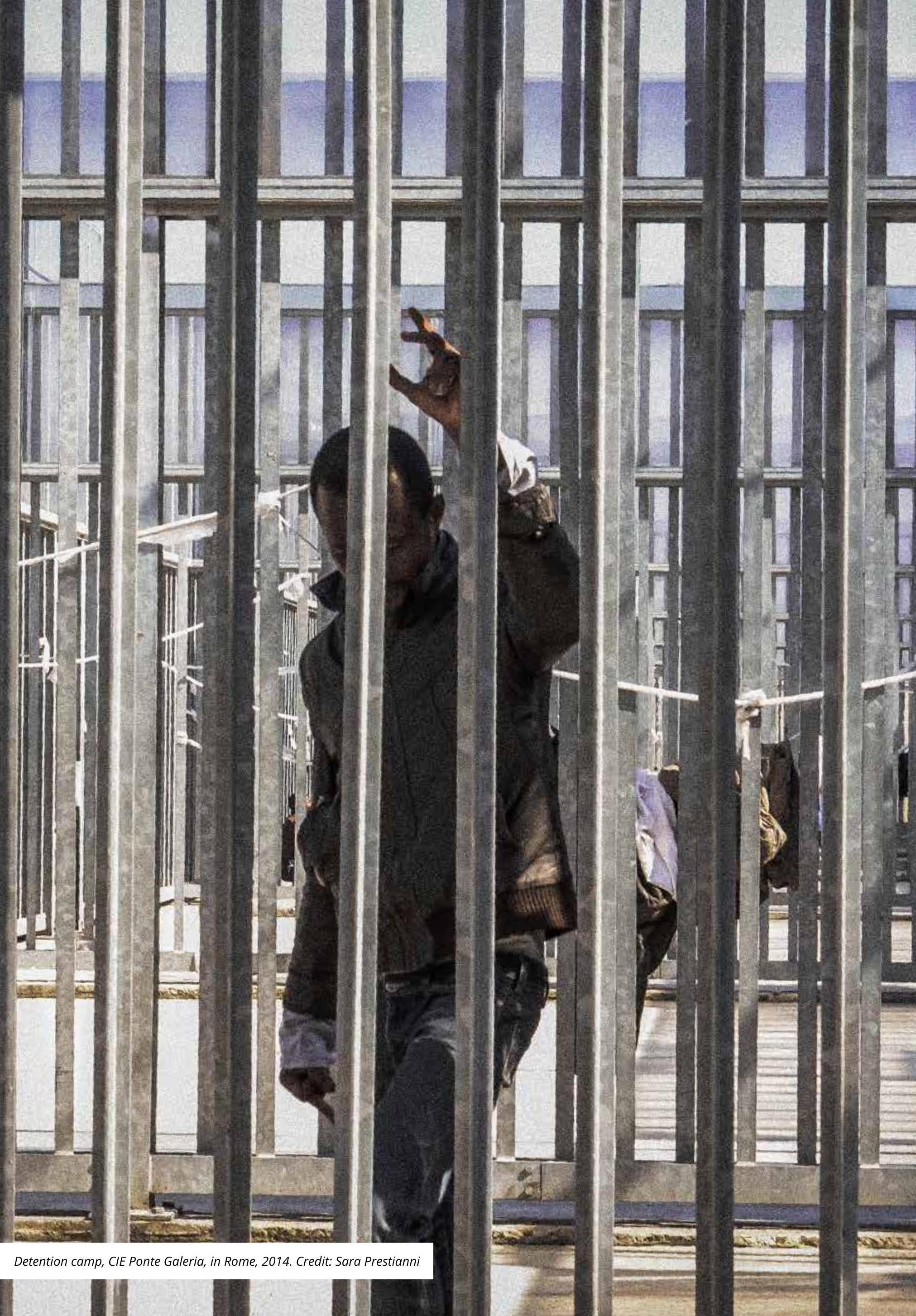




\section{BORDER WALLS INDUSTRY}

Our reports Border Wars and Expanding the Fortress showed that the military and security industries both shape and profit from the militarisation and externalisation of European borders.

\section{BORDER SECURITY MARKET}

The consultancy firm Visiongain estimated the global border security market to be worth approximately $€ 17.5$ billion in 2018, while Market Research Future, another consultancy firm, predicted that the revenues would grow by more than $8 \%$ annually in the coming years. ${ }^{123}$ Europe stands out with an expected annual growth rate of $15 \% .{ }^{124}$ Meanwhile, companies like Airbus and Thales are already looking further into the future, identifying Africa as the next growth market for border security and control. This is a safe bet, given that the EU is increasingly pressing nearby countries and regions such as North Africa to increase border militarisation to prevent migrants and refugees reaching Europe. ${ }^{125}$

\section{COMPANIES BUILDING WALLS}

While many (larger) companies are active in various fields relating to border security and control, research on the companies involved in building the land, maritime and virtual walls finds some division of labour:

- National or local construction or infrastructure companies, with military and security companies providing the accompanying technology, are the key corporations involved in land walls;

- Large military companies or national shipbuilders are the key providers of large assets - the vessels, helicopters and aircraft - critical to maritime walls. It is also not uncommon for states to buy these second-hand from other states' armed forces or coast guards;

- Biometrics and identity technology companies, which are sometimes part of large military and security companies, are the main winners of contracts for the virtual walls. 


\section{THE BIG PLAYERS}

Airbus, Leonardo and Thales are three of the largest European military and security companies. They offer a broad range of arms and security equipment and services, including for border security. They are involved in land, maritime and virtual walls alike and actively lobby for boosting and militarising border security, on their own and as prominent members of Europe's two largest security lobbying groups, the European Organisation for Security (EOS) and the AeroSpace and Defence Industries Association of Europe (ASD).

These companies profit from both sides of the plight of refugees. Not only are they the main beneficiaries of border militarisation, but are also important exporters of arms to the countries in conflict and authoritarian regimes many refugees seek to escape. ${ }^{126}$ These companies actively lobby against arms export restrictions as illustrated in the arms export ban Germany imposed on Saudi Arabia following the murder of the journalist Jamal Khashoggi in the Saudi consulate in Istanbul. The ban initially included the use of German arms parts in international projects, which also affected jointly produced French and UK arms.

Tom Enders, then Airbus CEO, attacked the ban and accused the German government of taking 'a kind of moral high ground attitude'127 His successor, Guillaume Faury, even suggested suing the German government over blocking Airbus from completing a large border-security contract with Saudi Arabia. His opinion that German's stance threatened the future of defence cooperation in Europe was echoed by Leonardo CEO Alessandro Profumo. ${ }^{128}$

\section{Largest European arms producing companies ${ }^{129}$}

\begin{tabular}{|l|l|l|l|r|r|r|}
\hline RANK (2017) & GLOBAL RANK & COMPANY & COUNTRY & $\begin{array}{r}\text { ARMS SALES AS } \\
\text { \% OF TOTAL SALES }\end{array}$ & $\begin{array}{r}\text { TOTAL REVENUES } \\
\text { (2017) IN \$ }\end{array}$ & $\begin{array}{r}\text { REVENUES FROM ARMS } \\
\text { SALES (2017) IN \$ }\end{array}$ \\
\hline 1 & 4 & BAE Systems & UK & 98 & 23.5 billion & 22.9 billion \\
\hline 2 & 7 & Airbus & Paneuropean & 15 & 75.2 billion & 12.9 billion \\
\hline 3 & 8 & Thales & France & 51 & 17.8 billion & 9.0 billion \\
\hline 4 & 9 & Leonardo & Italy & 68 & 13.0 billion & 8.9 billion \\
\hline
\end{tabular}




\section{Airbus is a Paneuropean aerospace and defence company. Most of its production takes place in Germany and France, but its headquarters are in The Netherlands, mainly for tax reasons.}

In March 2017, Airbus sold its border security and electronics division to the US private equity firm KKR \& Co for about $€ 1.1$ billion. While Airbus initially maintained a minority stake, the new company, rebranded as Hensoldt, bought this share and became completely independent in September 2018. ${ }^{131}$

Airbus itself remains active in the border security market, primarily through supplying helicopters. This has also been its main contribution to European border walls. Airbus helicopters have been used by Italy, ${ }^{132}$ France, ${ }^{133}$ Spain ${ }^{134}$, Belgium, ${ }^{135}$ Greece $^{136}$ Lithuania $^{137}$ and Germany ${ }^{138}$ in Operation Sophia, Operation Poseidon and in Operation Triton.

Airbus is also part of the first research project financed under the European Defence Fund: OCEAN2020, which is led by fellow arms firm, Leonardo (see below). ${ }^{139}$

Airbus companies and subsidiaries have participated in many EU-funded border security R\&I projects, including several aimed th the development and improvement of Eurosur. ${ }^{140}$ These include PERSEUS, in which Airbus received $€ 5$ million as part of a consortium led by Spanish technology company Indra, to provide 'recommendations for the European wide integrated maritime border control system'. ${ }^{141}$ Another project was LOBOS, seeking to demonstrate 'a pre-operational capability to deliver space-based monitoring in line with the requirements defined for the EU border surveillance service' [Eurosur]. ${ }^{142}$

Airbus is also involved in other space-based EU border security measures. The European Space Agency contracted an Airbus-led consortium in December 2017 for the Copernicus Data and Information Access Service, to make its data available to users. ${ }^{143}$ This data is used for a wide range of objectives, including monitoring migration and border security, and by various agencies including Frontex. ${ }^{144}$ The four-year contract, worth over $€ 10$ million, also includes Orange SA, Geo SA, Capgemini Technology Services SAS, CLS and VITO. ${ }^{145}$ 


\section{Like Airbus, the Italian arms company Leonardo (formerly Finmeccanica or Leonardo-Finmeccanica) is a leading supplier of helicopters for border security. Most of these were produced by the subsidiary AgustaWestland, which in 2016 merged into its parent company and was renamed Leonardo Helicopters.}

Italy extensively used Leonardo helicopters and airplanes in the Mare Nostrum, Hera ${ }^{147}$ and Sophia operations. During Sophia other Leonardo helicopters were deployed by Germany, Spain and the UK. The UK also contributed a Leonardo helicopter to Operation Triton. ${ }^{148}$

Leonardo has also been one of the main suppliers of UAVs (or drones) for Europe's borders. In 2017 it was awarded a contract by the European Maritime Safety Agency (EMSA) for 'Remotely piloted aircraft systems (RPAS) services in support of the execution of coast guard functions', with a total value of $€ 67.1$ million. ${ }^{149}$ EMSA shares the information gathered by the drones with Frontex, with which it increasingly cooperates. ${ }^{150}$

Frontex also selected Leonardo's Falco UAV for maritime border-surveillance tests in the Mediterranean in 2018. Leonardo received $€ 1.7$ million for 300 hours of test flights. ${ }^{151}$ The flights started in December 2018 from Lampedusa airport, under the auspices of the Italian Guardia di Finanza. ${ }^{152}$

The Falco has a controversial past, with Leonardo selling the UAV to clients including Jordan, Pakistan, Saudi Arabia and Turkmenistan ${ }^{153}$ - all countries at war, with internal armed conflicts, authoritarian regimes and governments accused of severe human rights violations.

Leonardo's involvement in European border walls is not restricted to maritime operations. In May 2019 eu-LISA awarded a €142.1 million four-year contract to implement and maintain its Entry/Exit System to a consortium of IBM Belgium, Atos Belgium and Leonardo. ${ }^{154}$

Telespazio, a joint venture owned by Leonardo (67\%) and Thales (33\%), is involved in several EU satelliteobservation projects, which are used for border monitoring. The company was, for example, part of a consortium REACT (Radar imagEry applications supporting ACTionable intelligence) that sought to improve geo-information and satellite imagery for the European Defence Agency, for which Frontex participated in 'Implementation sessions'. ${ }^{155}$

In April 2017, Telepazio was also part of a consortium for support work for Copernicus (the EU Earth Observation Programme, formerly known as GMES) awarded by the European Union Satellite Centre (Satcen). Under this 21-month contract worth $€ 7.5$ million, the consortium provided geo-information on critical but relatively inaccessible areas to support the EU in its security operations outside its own territory. ${ }^{156}$ The consortium was led by e-Geos (a joint venture of Telespazio (80\%) and the Italian Space Agency (20\%)), which also included Telespazio, GMV and Airbus. This geo-information will support EU and 
member states' military and security troops' increasing presence in non-European countries, aimed partly at stopping migration towards Europe, as part of the so-called externalisation of European borders. ${ }^{157}$

Leonardo also receives EU R\&I funding for border security and control projects, including for the development of Eurosur. Leonardo participated in at least 24 projects, of which it coordinated three. ${ }^{158}$ Its subsidiary Selex, now an integral part of the company, and Telespazio were part of the consortium for the CONTAIN project. CONTAIN sought to improve Copernicus' maritime services, i.e. the use of satellite observation, for Eurosur. ${ }^{159}$

Leonardo also leads the consortium for the first European Defence Fund research project, OCEAN2020, which aims to integrate unmanned naval platforms (drones) in maritime surveillance and interdiction missions, using satellites to connect drones and command and control of naval vessels to land centres. ${ }^{160}$ The project consortium also includes the French arms giant Safran, the Spanish technology firm Indra, Israel Aerospace Industries and the Dutch research institution TNO. ${ }^{161}$ 
Thales is a French arms and security company, with a significant presence in the Netherlands. Like Airbus and Leonardo, it offers a wide range of military and security equipment, and biometric identification systems.

One of its core activities is the production of radar and sensor systems. Many ships use Thales' radar, including those involved in border security. Thales systems were used, for example, by Dutch and Portuguese ships deployed in Frontex operations. ${ }^{163}$

In 2012, Thales (with the Spanish company Aerovision) also demonstrated the Fulmar UAV's capabilities to Frontex officials in Greece. Thales produces the maritime surveillance systems for these drones. ${ }^{164} \mathrm{In}$ January 2016 Thales was invited by Frontex to present proposals for tracking and controlling migrants and refugees before they reach Europe, for example by using smartphone apps. ${ }^{165} \mathrm{It}$ is also working on a feasibility study for the use of High Altitude Pseudo Satellites (HAPS), including for border security, for the European Space Agency and Frontex. ${ }^{166}$ The use of HAPS for border security was promoted by the ASD lobby organisation in a 2017 white paper with proposals for the EU Multiannual Financial Framework budget for 2021-2027. ${ }^{167}$

Thales was also one of the subcontractors for a technical study to 'develop[ing] concepts for border surveillance infrastructure, a secure communication network and a pre-frontier intelligence picture within the framework of EUROSUR', financed by the EU External Borders Fund. ${ }^{168}$ In addition,Thales Security Systems currently provides the security system for the highly militarised port in Calais. This surveillance and access control system includes revolving doors, IP cameras (security cameras connected to a network) along the fence, and a monitoring station. ${ }^{169}$

In 2019 Thales acquired Gemalto, a large (biometric) identity security company, for €4.8 million, integrated as its Digital Identity and Security (DIS) division. ${ }^{170}$ In 2017, Gemalto had bought 3M's Identity Management Business, which included Cogent Systems (bought by 3M in 2010) for $\$ 850$ million. ${ }^{171}$ Between 2000 and 2017 Cogent and 3M were returning partners in a consortium led by Sopra Steria for several large EU contracts for the development and maintenance of EURODAC, VIS and SIS II. ${ }^{172}$ Gemalto, formerly Cogent, also supplies fingerprint identification technology for the EURODAC database. ${ }^{173}$

Like Leonardo and Airbus, Thales, a prominent member of EOS and ASD, was represented in several official advisory groups regarding EU funding for security and military R\&I. ${ }^{174}$ It then profited from the EU's translation of the advice given by those industry-dominated groups into policy. Thales was or is involved in at least 27 EU-funded border security research projects, often cooperating with Leonardo. In 2008, it led the consortium for the OPERAMAR project, aimed at developing 'a sufficient interoperability of current maritime security management systems'. ${ }^{175}$ 


\section{ISRAELI COMPANIES}

The participation of Israeli arms and security companies in building the border walls in Europe is remarkable, but not altogether surprising. Israeli companies are at the forefront of the international border security market. Their unique selling strategy capitalises on their involvement in Israeli border security, including the Separation wall on the West Bank and the fence on the border with Egypt.

Many of such Israeli companies shamelessly promote themselves as 'battlefield proven'. ${ }^{176}$ As the Stop the Wall Campaign notes: 'Companies [...] benefit from the ability to test Wall-related surveillance, detection, and scanning technologies on a captive population'. ${ }^{177}$ In a bid for European border security contracts, Saar Koush, then CEO of Magal Security, which built the wall on the West Bank, said: 'Anybody can give you a very nice Powerpoint, but few can show you such a complex project as Gaza that is constantly battle-tested'. ${ }^{178}$

In 2015, Bulgaria and Hungary publicly toyed with buying Israeli-designed border fences. Though both countries eventually chose other companies, Israel's experiences offered an inspiration. ${ }^{179}$ In terms of land walls, Israeli companies have so far been more successful in the US market. In 2014, Elbit Systems of America, a subsidiary of the Israeli arms company Elbit, won a contract to build a network of 55 surveillance towers on the border between Mexico and the US state of Arizona. ${ }^{180}$ In 2019, Elbit was also awarded a $\$ 26$ million contract to install a multi-sensor monitoring system on the US-Mexico border. ${ }^{181}$ Elta North America, a subsidiary of Israel Aerospaces Industries (IAI), was one of the eight companies picked in 2017 to build a prototype of Trump's US-Mexico border wall. ${ }^{182}$

In 2018 Frontex selected the Heron drone from Israel Aerospace Industries for pilot-testing surveillance flights in the Mediterranean. The deal was worth $€ 4.75$ million for 600 hours of test flights, with IAI winning the contract over two EU competitors. ${ }^{183}$ IAI partnered with Airbus DS Airborne Solutions to undertake the flights, with the first series flown from Crete (Greece). ${ }^{184}$

Frontex was first shown the Heron in early 2012, when several arms manufacturers showcased their drones for border security in Greece. ${ }^{185}$ At the time Frontex was very keen on the use of drones, but these have proved difficult to operate owing to varying aerospace regulations in the EU.

The Heron is used by militaries all over the world, including India, Morocco, Turkey and the United States, but Israel is its main user. It used the Heron drones, armed with Spike missiles, in the 2009 war in Gaza. According to Human Rights Watch, the use of drones 'led to the loss of many civilian lives', because of 'Israel's targeting choices'. ${ }^{186}$

Elbit has also developed fully autonomous military vehicles, so-called 'Border Protector Unmanned Ground Vehicles (UGVs)', for use by the Israel Defence Forces (IDF) at Israel's borders. ${ }^{187}$ In Europe, in 2015 Elbit sold six Hermes UAVs to Switzerland's Border Guard, in a controversial €230 million deal. ${ }^{188}$ The UAVs also featured in a 2018 contract, worth $€ 59$ million, between the European Maritime Safety Agency (EMSA) and the Portuguese company CEIIA, for 'long endurance and long range RPAS services in the civil maritime surveillance domain'. ${ }^{189}$ As subcontractor, Elbit will operate the Hermes for longrange maritime surveillance, a service EMSA makes available to EU member states and associated countries. 'Having been selected by the European Union authorities is yet another vote of confidence in the Hermes 900', said Elad Aharonson, Elbit's general manager. ${ }^{190}$ In June 2019 Elbit started flying the Hermes for Iceland. ${ }^{191}$ 
In 2019, the Italian shipbuilder Cantieri Navali Vittoria awarded Elbit Systems a contract to supply combat suites (weapons, sensors, radars and electro-optical systems) and integrate systems for three new patrol vessels for the Hellenic Coast Guard. ${ }^{192}$ The construction of the vessels, due for delivery in 2020 , costs $€ 55.56$ million, of which $90 \%$ is financed by Frontex. ${ }^{193}$ In exchange Greece will assign them to Frontex operations outside Greek waters for four months per year. ${ }^{194}$ Cantiere also built patrol vessel 'Monte Sperone', based on a Damen design, which Italy deployed in Operation Triton. ${ }^{195}$ According to its website, the company has delivered 'more than a hundred vessels' to 'the Coast Guards of Croatia, Cyprus, Italy, Libya, Malta and Tunisia.'196

\section{LAND WALL CONTRACTORS}

The walls and fences erected on European borders vary considerably. Some are meant to be temporary, with simple chain-link fences, while more permanent ones come with a whole set of surveillance, intrusion and detection technology.

Whatever they look like, their role is largely symbolic. They signal to the national media and the public as well as the international community and people on the move that governments take border 'security' seriously. ${ }^{197}$ Professor Reece Jones describes border walls as 'effective [as] symbols that demonstrate that politicians are doing something to address the perceived threats brought by unauthorized movement. These perceived threats can be economic in the form of smugglers or workers taking revenue and jobs from citizens. They can be cultural in the sense that migrants bring different traditions, languages, and ways of life that might not match with the local culture'. ${ }^{198}$

According to the historian Eric Schewe: 'Erecting physical barriers is much easier than addressing the economic and political causes of migration under duress'. ${ }^{199}$ Even the most high-tech fencing, like that at Ceuta and Melilla, does not stop people from crossing borders, but makes it more dangerous to do so by forcing people to get over or around these obstacles, with additional risks of injury, violence or death. ${ }^{200}$

The fences or concrete walls themselves are often built by local building firms, rather than by international military or security companies. Frequently the costs far exceed original estimates. In at least four countries (Bulgaria, Latvia, Slovenia and Spain) there have been allegations of, and investigations into, possible corruption surrounding border wall deals. As both the arms and security and the construction and infrastructure sectors are are particularly susceptible to corruption, projects that rely on these industries run high risks in this regard. ${ }^{201}$ 


\section{EUROPEAN SECURITY FENCING TOTAL REVENUE (2018): UNKNOWN}

European Security Fencing (ESF) is a Spanish producer of razor wire and concertinas. It is part of corporate group Mora Salazar and involved in 'manufacturing, distribution and installation of fences system, road safety features and passive safety'. ${ }^{202}$

ESF used to proudly promote itself as the only producer of razor wire in Europe, but is more reluctant to acknowledge its involvement in border barriers, refusing most interview requests and telling the press it did not know for what purposes customers were using its products. ${ }^{203}$

Since 1998, Mora Salazar and ESF (established in 2003), have been involved in the border fences installed around the Spanish enclaves of Ceuta and Melilla in Morocco. ${ }^{204}$ In 2005, razor wire - known as concertinas - was for the first time attached on the top of these and resulted in severe cuts to anyone trying to climb over them. In September that year, the Spanish media reported that a 30-year old Senegalese refugee had bled to death after his neck was caught in the razor wire at Ceuta. ${ }^{205}$

In 2007, the wire was removed, only to be re-installed in 2013, when the fences were also raised from three to six metres. Civil society organisations (CSOs) criticised the decision, but the Spanish government and ESF claimed that the razor wire was not meant to harm people, only to deter them from attempting to cross from Morocco into Spanish territory. ${ }^{206}$ In June 2018, the Spanish Red Cross said it had treated 25 people for cuts on the barbed wire in Ceuta and Melilla in that year alone, ten of whom were hospitalised. ${ }^{207}$ The same month, shortly after taking office as Minister for the Interior, Fernando Grande-Marlaska announced that Spain would again remove the concertinas, as a matter of priority. In January 2019 the government confirmed their planned removal, though at the time of writing (mid-2019) they were still in place. ${ }^{208}$

ESF has profited from the increased number of border walls and fences since 2015 , with a steady increase in production and sales. ${ }^{209}$ It delivered the razor wire for the fence on the border between Hungary and Serbia, and its concertinas were also installed on the borders between Bulgaria and Turkey and Austria and Slovenia, as well as at Calais, and for a couple of days on the border between Hungary and Slovenia before being removed. ${ }^{210}$ Given its long-term monopoly in the fencing market, its concertinas are likely to be used at other borders in Europe. In September 2015, the company proudly tweeted that all of the razor wire in Europe came from its factory. A social media backlash led ESF to delete its Twitter account a few days later. ${ }^{211}$

\section{AUSTRIA:}

The fence on the border between Austria and Slovenia was installed by Tirol-based firm Geo Alpinbau, starting in December 2015. To save costs the Austrian army did part of the work. ${ }^{212}$ In cooperation with the Munich police force, the company had developed this type of security fence for the G7 Summit earlier that year. ${ }^{213}$

For the first six months the Austrian authorities leased the fence, for a total of $€ 331,000$, later purchasing it for $€ 168,000$. The fence has been criticised in the media as mainly symbolic since during its construction scarcely any refugees were trying to cross the border anyway. ${ }^{214}$ There are also several gaps in the fence, because some landowners refused to have it built on their property. ${ }^{215}$ 


\section{BULGARIA: ${ }^{216}$}

The Bulgarian army installed a fence on the border with Turkey. There was some controversy about the costs being much higher than estimated, and about delays in completion. In the end, the fence cost almost $€ 88$ million, way more than the government's original estimate of $€ 2$ million. ${ }^{217}$ According to research by the investigative website Bivol.bg, this was mainly due to overpriced contracts by several construction companies, which hoped to pocket the difference by taking on cheaper subcontractors. It alleges that for the part of the fence in the Burgas region, four overpriced contracts were awarded to Patstroy Bourgas, Infra Expert and Patengineeringstroy. Patstroy Bourgas is fully owned by Hydrostroy, which also has connections to Infra Expert. Hydrostroy allegedly used the profits from these lucrative contracts to buy yet another company, Vodstroy - 98, eventually ending up in the pockets of then MP Delyan Peevski of the Movement for Rights and Freedoms (DPS), who controlled the firm. ${ }^{218}$ On several occasions, Peevski, who also owns much of the Bulgarian media, has been accused of corruption and influence peddling by Reporters Without Borders and the Union of Publishers in Bulgaria, among others. ${ }^{219}$

Other companies contracted to supply material for or to build the fence were Geostroy Engineering and Metallic-Ivan Mihaylov. The Bulgarian government, with the support of a parliamentary majority, waived an open-tender process. It argued this was to prevent delays by avoiding potential appeals against contracts awarded. ${ }^{220}$ Despite the controversies, the open-tender process was waived again in March 2018 for new contracts to repair the fence. ${ }^{221}$ In December 2018, part of the fence collapsed for the second time following heavy rainfall. The regional government said that the contractor was not at fault. ${ }^{222}$

Armed border guards monitor strategic points along the fence, which is also equipped with a surveillance system of infrared, motion-sensitive cameras. ${ }^{223}$ Approximately $75 \%$ of the total costs of $€ 20$ million for this system, which was provided by Indra, came from the EU External Borders Fund. ${ }^{224}$ In March 2019, the Bulgarian national border police received 70 new off-road vehicles for patrolling the fence, for which $€ 3.5$ million was from the EU's Internal Security Fund as part of an Emergency Assistance package. ${ }^{225}$

\section{ESTONIA:}

The building of a fence on the Russian border is part of a larger border security programme. The Interior Ministry spokesperson, Toomas Viks, stated in 2015 that 'the aim of the construction is to cover the land border with 100\%, around-the-clock technical surveillance to create ideal conditions for border guarding and to ensure the security of Estonia and the Schengen area'. ${ }^{226}$

The construction company Nordecon was contracted to build the fence. Nordecon is mainly involved in civil engineering and road and building construction. It also built the Piusa border guard station in Estonia, together with real-estate company Riigi Kinnisvara AS, for €4.62 million. ${ }^{227}$

Once again, the cost far exceeded original estimates and there were many delays. Construction costs rose from an estimated $€ 71$ million to $€ 250$ million in 2018 , with a further $€ 70$ million for maintenance. ${ }^{228}$ Nordecon and the Police and Border Guard Board explained that the rise in costs and the delays were due to difficult topographical conditions - a swamp meant that extra foundations were needed - as well as the fact that a larger area of land had to be purchased from sometimes reluctant owners. They also said the pressure in 2014-15 to produce a rapid estimate meant the budget was miscalculated from the outset. ${ }^{229}$ In August 2019, the government eventually scrapped part of the original plan, which included 
a wildlife fence, and reduced the estimated total cost to $€ 130.5$ million. ${ }^{230}$ It also released a new tender for automated border control gates, expected to cost some $€ 5$ million, and announced it was planning to apply for $€ 40$ million from the EU to buy surveillance systems for the fence. ${ }^{231}$

The Estonian surveillance technology firm Defendec was also involved in the border security programme.. ${ }^{232}$ This is despite its CEO, Jaanus Tamm, saying in 2017 that the company 'believe[s] that building walls and fences in large volumes is neither efficient nor reasonable' and that 'building a wall along an entire border is not 'a reasonable thing to do'. 233

The flagship product of Defendec is Smartdec, a remote monitoring system with wireless cameras programmed to recognise only human motion. ${ }^{234}$ It has been sold to various European countries, including Bulgaria, Finland, Lithuania and Romania. ${ }^{235}$ In 2011, the US Embassy in Albania donated Smartdec systems to the Albanian Border Guard. 236

In 2016 the Ukrainian State Border Guard received four sets of Defendec wireless detection systems, as part of a larger package of border security equipment from the EU, through a project - implemented by the International Organization for Migration (IOM) - to strengthen the capacities of border guards in Ukraine and Belarus. ${ }^{237}$

\section{GREECE:}

The fence on the border with Turkey is one of the pre-2015 border barriers against migration in Europe. While planned from early 2011, a contract with an undisclosed company was not signed until January 2012. ${ }^{238}$ In the meantime, the Greek government asked for EU funding for the fence, which the European Commission rejected. ${ }^{239}$

Construction started in April 2012 and was completed in December that year. ${ }^{240}$ During this time refugees continued to cross the border. Someone from the building company said: 'We see families, once even a four-month-old baby. They were wet from the river'. ${ }^{241}$

\section{HUNGARY:}

The razor-wire concertinas, provided by ESF, for the fence on the border with Serbia were assembled by prisoners from the Palhalmai jail in Dunaujvaros and an unnamed factory nearby. ${ }^{242}$ The columns for the fence were placed with pile-driving technology by DAK Acélszerkezeti Kft from Sándorháza. ${ }^{243}$

Earlier, in a rare rejection of potential business, the German razor-wire manufacturer Mutanox said it would not sell to the Hungarian government: 'Razor wire is designed to prevent criminal acts, like a burglary. Fleeing children and adults are not criminals'. ${ }^{244}$

The Hungarian authorities used unemployed persons, prisoners (paid a third of the minimum wage) and soldiers, to install the fence, in an effort - albeit for good publicity - to keep costs down. Even so, the cost of the fence on the border with Serbia, including a second electronic fence, and with Croatia, still rose to some $€ 440$ million. Orban's government requested that the EU pay half of this sum, which was rejected. 245 


\section{LATVIA:}

In August 2015, SIA ‘Ceḷu būvniecības sabiedrība IGATE' from Jelgava was awarded a contract for $€ 17.49$ million to build 'border zone infrastructure' on the border with Russia. ${ }^{246}$ IGATE is a road-building company, which, does not seem to have done any other border security work. ${ }^{247}$ In September 2018 , the Internal Security Bureau detained the former head of the Latvian State Border Guard, Normunds Garbars, and two IGATE employees on suspicion of financial fraud in connection with the border fence project. ${ }^{248}$

The fence was part of a larger infrastructure project on the border with Russia and was erected following predictions of increased irregular border crossing. In March 2019, $93 \mathrm{~km}$ of fence were finished, but there was uncertainty about whether the fence would be continued a further $100 \mathrm{~km}$ at an additional cost of $€ 5.6$ million. ${ }^{249}$ Meanwhile the government aims to build a fence on the border with Belarus once the Russian border fence is completed. ${ }^{250}$

\section{LITHUANIA:}

The Vilkaviškis-based company Gintrejja built the fence on the border with Russia in the second half of 2017. ${ }^{251}$ Gintreja is a broad company, which next to construction and real estate rental also runs a restaurant and a bowling alley and provides party services. It won the $€ 1.34$ million contract over 27 companies that took part in the public tender. Gintreja did not build the fence but bought it from another Lithuanian company, which it refused to name..$^{252}$

The government allocated $€ 3.6$ million for the fence. ${ }^{253} \mathrm{It}$ was part of an overall plan to increase border security, that included the purchase of a new patrol vessel, high-speed boats, and drones. According to Renatas Požèla, chief of the State Border Guard Service, the fence would later be equipped with a surveillance system. ${ }^{254}$ Again, the European Commission said it would not fund the fence, but that Lithuania could use EU funding for the surveillance system. ${ }^{255}$

\section{MACEDONIA:}

The Macedonian army built the fences on the border with Greece. It began erecting the first fence in November 2015, amid protests by refugees at the border, who clashed with the police. ${ }^{256}$ In February 2016, a bigger fence was built five metres behind the first one. ${ }^{257}$ Hungary's border fences served as a model for the one in Macedonia, with Hungary donating razor wire fencing, probably from European Security Fencing. ${ }^{258}$ Hungary and Slovenia both sent border officers to Macedonia to assist in border patrols, using their own equipment, including vehicles and night-vision goggles. ${ }^{259}$

The European Centre for Constitutional and Human Rights (ECCHR) and the German NGO Pro Asyl reported several incidents where refugees, who had already entered Macedonia, were refouled to Greece. In one case they were ordered to crawl under the border fence back into Greece. ${ }^{260}$

The IOM supports the Macedonian authorities through the 'Special Measure supporting the Former Yugoslav Republic of Macedonia to manage its southern border in the context of the European Migration Crisis', which ran for three years from March 2016. The EU provided €9 million for this programme, which was spent on equipment, such as patrol vehicles and night vision cameras, as well as on services for national and foreign border police, including board and lodging. ${ }^{261}$ According to the IOM 'the new and 
advanced technological equipment donated, mainly consisting in thermovision cameras with short and long range, heart beat detectors, systems for high level document examination and systems for border surveillance, has significantly contributed to the combating and prevention of smuggling of migrants and trafficking in human beings'. ${ }^{262}$

One of the largest grants under this measure was for a $€ 2.14$ million contract with the Slovenian company DAT-CON, for the provision of a 'Local Deployable Coordination \& Communication Centre and Mobile Surveillance Systems equipped with EO-IR cameras and radar'. Border authorities in the region are regular customers of DAT-CON. It has also sold stationary thermal-imaging systems to Croatia, which are placed at three border locations, a coastal surveillance system to Cyprus, surveillance vehicles with thermal cameras to the Greek coast guard and the Moldovan Border Police and thermal surveillance equipment to Croatia, Slovakia, Slovenia and the Ukraine State Border Guard Service. ${ }^{263}$

\section{NORWAY:}

It is not known which company delivered and/or built the fence at the border between Norway and Russia in September 2016, but press reports claim a private contractor was involved. There was some controversy surrounding the fence, both about the plan itself, given that few refugees take the long route to Russia to enter Europe and about the existence of a wall on the Russian side along the whole border, a relic from the Cold War. Then, during construction, it was discovered that the 200-meter fence at the northern town of Storskog was a few centimetres too close to the border, so the Norwegian authorities eventually decided that a 50-metre part of the fence had to be moved. ${ }^{264}$

\section{SLOVENIA:}

In November 2015 the Slovenian army built a wire fence on the border with Croatia, in cooperation with the police and a company called Minis from Žalec. ${ }^{265}$ The same company was contracted to replace the wire fence with a panel fence a few months later. ${ }^{266}$ The Croatian government was dissatisfied with the fence, however, calling it an 'unnecessary waste of money'.267

The Slovenian media and some politicians criticised the contract, noting that Minis was a small, unknown company, without relevant experience. ${ }^{268}$ Questions were also raised about how the contract was awarded and whether Minis had in fact been the cheapest bidder. When it emerged that Minis and a local office of the Modern Centre Party (SMC), the senior national coalition party between 2014 and 2018, shared the same address for a while, there were further allegations of corruption. ${ }^{269}$

In March 2019, after a three-year legal battle that reached the Supreme Court in order to get access to contract related government documents, Transparency International Slovenia brought a case to the state prosecutor against Anton Zakrajšek, director of the Agency for Commodity Reserves, regarding suspected abuse of office. The investigation is continuing. ${ }^{270}$

In mid-2019, the Slovenian government decided to extend the fence another $40 \mathrm{~km}$ along the River Kolpa, because of an increase in refugees crossing the border. The Serbian company Legi-SGS was awarded $a € 4.8$ million contract for this work. ${ }^{271}$ Meanwhile, far-right vigilante groups have started patrolling the border fence between Slovenia and Croatia and handing over refugees to the police, a move welcomed by them, although highly suspect and probably illegal. ${ }^{272}$ 


\section{SPAIN:}

The EU funded part of the costs for the first fence built between the Spanish enclaves of Ceuta and Melilla at the end of the 1990s, and has continued to fund other elements of their overall border security. Money from the External Borders Fund was used for security services and for a new CCTV command and control centre at Melilla, among other elements of the border infrastructure. ${ }^{273}$

In 2006 Indra received a $€ 7$ million contract to build a third fence, and a further $€ 3.9$ million to strengthen the fence at Melilla. ${ }^{274}$ Indra also developed the SIVE border control system (with radar, sensors and vision systems), which is in place on most of Spain's maritime borders, including Ceuta, as well as in Romania and Portugal. In July 2018 it won a contract worth $€ 10$ million for maintenance of SIVE at several locations, including Ceuta, for the next two years. ${ }^{275}$

Indra is very active in lobbying the EU and is one of the major beneficiaries of R\&I funding for border security projects. It coordinated the PERSEUS project to further develop Eurosur, and also developed the Seahorse Network between police forces in Mediterranean countries in Europe and North Africa to stop migration. ${ }^{276}$ The EU funds the project, including purchase of equipment by North African countries for satellite connections to the National Coordination Centres for Eurosur of the European participants. ${ }^{277}$

A report by the PorCausa Foundation lists other companies that received contracts for the Ceuta and Melilla fences between 2005 and 2016.

\section{Contracted companies for work at Ceuta and Melilla border fences (2005-2016) ${ }^{278}$}

\begin{tabular}{|l|l|r|}
\hline COMPANY & DESCRIPTION & TOTAL VALUE OF CONTRACTS \\
\hline Dragados & 11 contracts for the construction of the fences and their repair & $€ 17,717,938$ \\
\hline Ferrovial & Nine contracts for the construction and maintenance of the fences & $€ 15,320,016$ \\
\hline Proyectos Y Tecnología Sallén & Four contracts for maintenance of the border perimeter 279 & $€ 5,018,871$ \\
\hline Eulen & 25 contracts for security in Melilla & $€ 9,186,428$ \\
\hline Initec Infraest & $\begin{array}{l}31 \text { contracts for design, projection, technical assistance and construction } \\
\text { of the border fences and perimeters }\end{array}$ & $€ 2,654,254$ \\
\hline Acciona & Four contracts for works in the border perimeter of Melilla & $€ 1,794,843$ \\
\hline Mora Salazar & Three contracts for installation of fences at Ceuta and Melilla & $€ 1,138,271$ \\
\hline
\end{tabular}

In December 2017 Ferrovial won another contract, worth $€ 4.5$ million, for the maintenance of the fences. ${ }^{280}$ Some of the companies that received the most lucrative contracts, including Indra, Dragados and Ferrovial, are or have been investigated for making illegal donations to the right-wing political party, el Partido Popular. 281

In 2018 the government started a new $€ 32.7$ million project to remove the concertinas on the fences, but at the same time raised the fences to 10 metres and increased surveillance. ${ }^{282}$ In early 2019 , the government announced that it had contracted the arms company ISDEFE to conduct a preliminary study into modernising border security at Ceuta and Melilla. ${ }^{283}$ In June 2019 it was reported that Spain had replaced old cameras, installed new ones and had set up a new CCTV platform. ${ }^{284}$ 


\section{UK/FRANCE:285}

At several locations around Calais, border walls and fences have been built to stop refugees from entering the port and the Channel tunnel. Various companies were involved. ${ }^{286}$

\section{Company}

\begin{tabular}{|l|l|}
\hline GROUPE CW (CLÔTURES MICHEL WILLOQUAUX) & FENCES AT THE CONTAINER CAMP \\
\hline Jackson's Fencing & Fences and gates at the Eurotunnel site \\
\hline Sorhea & Infrared barriers along the port fence \\
\hline Vinci & Building of the 'Great Wall of Calais' \\
\hline Zaun Ltd. & Fence surrounding the port of Calais \\
\hline
\end{tabular}

The fence from Zaun was originally part of the extreme security measures installed before the 2014 NATO Summit in Newport (Wales) and was subsequently given to France. As the then Immigration Minister James Brokenshire wrote in an op-ed in The Telegraph: 'We will offer our French partners the fences that were used this week to keep the Nato Summit safe in Newport. These could replace and enlarge the inadequate fencing at Calais, which is too easy for illegal immigrants to scale' ${ }^{287}$

Eurovia - a subsidiary of French company Vinci, the world's largest construction company - was one of the companies involved in building the four-metre high security wall, known as the 'Great Wall of Calais'. This wall, located between the former 'Jungle' camp where many refugees stayed before attempting to cross to the UK, and the motorway to the busiest port, was completed two months after the 'Jungle' was demolished, raising questions about its usefulness. The mayor of Calais, Natacha Bouchart, had tried to stop the wall, arguing that it had become unnecessary, but her attempts were blocked by the courts. ${ }^{288}$

\section{MARITIME WALL CONTRACTORS}

For the operations by Frontex and others in the Mediterranean, the large equipment, such as vessels, helicopters and aircraft, is provided by EU member states. The main players include the European arms giants Airbus and Leonardo, as well as large ship-building companies including the Dutch Damen and Italian Fincantieri, although many countries favour their own maritime industry.

Information about which ships, helicopters and aircraft are used in these maritime operations is hard to track. Frontex is particularly reluctant to publish specific information, but it does name certain vessels in press releases and stories on its website. Often its reports are about rescuing refugees from sea, which tend to give a distorted view of the operations and their actual goals: stopping and preventing migration to Europe.

Frontex director Fabrice Leggeri was very clear about this. In April 2015 he told the Guardian that Frontex has no a mandate for 'proactive search-and-rescue action[s]' and that saving lives should not be a priority. ${ }^{289}$

The thwarting of NGO rescue operations in the Mediterranean and the general hindering and criminalisation of their actions by the EU, member states and third countries, point in the same direction, ${ }^{290}$ as do reports of violence against and the illegal refoulement of refugees, in the context of Frontex operations or by coast guards from EU member states and third countries cooperating with the EU. ${ }^{291}$ 
The main reason why humanitarianism is not at the heart of maritime operations, however, is due to policies to close off migration routes and militarise borders (of which the various walls are part). This not only promotes increased violence against migrants and refugees persons, but also forces them to look for other, often more dangerous, routes - pushing them into the hands of criminal smuggling networks and thus creating the very market that the EU says it wants to dismantle.

The increased danger for refugees trying to cross the Mediterranean translates into a correspondingly greater number of deaths. While recorded deaths have declined since 2016, the proportion of people losing their lives in trying to cross has grown, indicating a riskier journey.

\section{Migrant arrivals and deaths - Europe via Mediterranean ${ }^{292}$}

\begin{tabular}{|l|r|r|r|}
\hline YEAR & ARRIVALS TO EUROPE VIA MEDITERRANEAN & RECORDED DEATHS (MEDITERRANEAN) & RATIO DEATHS: ARRIVALS (\%) \\
\hline 2015 & $1,012,179$ & 3,783 & $1: 268(0.37 \%)$ \\
\hline 2016 & 363,401 & 5,143 & $1: 71(1.42 \%)$ \\
\hline 2017 & 172,152 & 3,139 & $1: 55(1.82 \%)$ \\
\hline 2018 & 116,273 & 2,297 & $1: 51(1.98 \%)$ \\
\hline
\end{tabular}

\section{DAMEN TOTAL REVENUE (2018): $€ 2.0$ BILLION ${ }^{293}$}

The Dutch shipbuilder Damen is an important player in the global maritime military and security market. It has shipyards in many of countries, including Cuba, Romania, Turkey and Vietnam. In the Netherlands Damen has been the subject of several investigations into allegations of corruption surrounding export deals, mostly related to dubious intermediaries with which it has worked. ${ }^{294}$

Many European border forces deploy Damen's patrol vessels, including Albania, Belgium, Bulgaria, the Netherlands, Portugal, Romania, Sweden and the UK. Romania's purchase was partly funded by the EU under the Schengen Facility programme. Italy and Malta use ships based on Damen designs, but built by other companies. ${ }^{295}$ Many Damen vessels were used in Frontex operations (including Poseidon ${ }^{296}$, Triton ${ }^{297}$ and Themis ${ }^{298}$ ), Operation Sophia and in supporting NATO's role in support of Operation Poseidon. 299

On the other side of the Mediterranean, Libya, Morocco, Tunisia and Turkey use Damen vessels for border security, often in cooperation with the EU or its member states. Most of the deals have been controversial. Damen supplied four patrol vessels to the Libyan Coast Guard in 2012, which were sold as civil equipment in order to get around obtaining an arms export license from the Dutch government. A research team found, however, that the ships were not only sold with mounting points for weapons, but were then armed and used to stop refugee boats. Several incidents involving these boats have been reported, including one where 20 to 30 refugees drowned. Damen refused to comment, saying it had agreed with the Libyan government not to disclose information about the ships. ${ }^{300}$

The deals with Morocco for corvettes (2008) and fast patrol boats (Interceptors, 2015) were criticised because of their enormous cost, money that could have been better used to address the country's extreme poverty. There were also concerns about the possible use of such equipment for border security and to prolong the occupation of Western Sahara. ${ }^{301}$

Turkey ordered six vessels for its coast guard in 2016 using $€ 20$ million from the EU Instrument contributing to Stability and Peace (ICSP), intended for peace-building and conflict prevention. ${ }^{302}$

Mid-2019 Damen signed a contract for another nine vessels for the Turkish Coast Guard, again funded by the EU." ${ }^{\prime 303}$ 


\section{FINCANTIERI \\ TOTAL REVENUE (2018): $€ 5.5$ BILLION ${ }^{304}$}

Fincantieri is a shipbuilder based in Trieste, with several shipyards in Italy, as well as in Norway and the United States. It is mostly known for building cruise ships. Most of Fincantieri's military ships are in service in Italy.

Many Fincantieri military ships, ranging from landing platform docks to patrol vessels, took part in Italy's Operation Mare Nostrum and in Operation Sophia. Italy ${ }^{305}$ and Malta ${ }^{306}$ also deployed Fincantieri ships in the Frontex Operation Triton. Furthermore, Fincantieri is part of the consortium for OCEAN2020, the first research project financed under the European Defence Fund. ${ }^{307}$

Fincantieri has sold military ships to the navies of Algeria, India, Iraq and the UAE, but its European market remains limited. In June 2019, it signed an agreement with the French Naval Group to create a 50:50 joint venture. 'We are by far the two largest European naval players, but if we rely on our domestic markets alone we cannot maintain our resources and remain competitive', according to Herve Guillo, CEO of Naval Group. ${ }^{308}$

\section{FRONTEX OPERATIONS}

Frontex does not disclose which ships and aircraft are used in its operations. When asked through Freedom of Information requests it has repeatedly refused to disclose this information, citing strategic reasons, especially with regard to on-going operations. ${ }^{309}$

Frontex does occasionally name specific assets in press releases and stories on its website, as do national authorities and media outlets. This fragmented view gives some insight into the ships and aircraft used and the companies that produce them. Many shipyards that produced some of the older ships still in service have been closed or sold, like Boelwerf in Belgium or the ENVC Shipyard in Portugal. Other ships were originally used for other purposes and then resold to border security authorities.

The Greek company Motomarine Shipyards produced the Panther 57 Fast Patrol Boats, used by the Hellenic Coast Guard, particularly during Operation Poseidon and Operation Triton. ${ }^{310}$ Motomarine also sold patrol boats to Burundi, Guinea and Saudi Arabia, all of which have a bad human rights record. ${ }^{311}$ Other patrol vessels used in Operation Poseidon by Greece were built by Hellenic Shipyards and by Israel Shipyards. The latter also sold patrol ships to Cyprus, but is predominantly a major provider of military ships for the Israeli navy. In the 1970s it secretly sold military vessels to the Apartheid regime in South Africa, defying an international arms embargo. ${ }^{312}$

Most of the ships Romania deployed to Operation Poseidon were built by the German Lürssen shipyard, part of the Lürssen Gruppe. ${ }^{313}$ As well as the Germany navy, the navies of countries such as Egypt, Indonesia, Saudi Arabia, Turkey and the UAE use its ships.

The Netherlands and Finland deployed Dornier aircraft in Operation Poseidon and Operation Hermes respectively, and in Operation Triton. ${ }^{314}$ Dornier started as a German company, but after various takeovers is now part of the US subsidiary of Israeli arms company Elbit Systems. ${ }^{315}$ The Dutch company EASP Air used a Dornier aircraft to support Operation Indalo. ${ }^{316}$ Since 2015, EASP Air has performed maritime surveillance flights for Frontex. That year it was one of several companies selected by the agency for a $€ 10$ million contract, followed by a new €14.5 million contract in December 2017.317 In February 2019, this contract was extended for another four years. ${ }^{318}$ Together with CAE Aviation (Luxembourg) and DEA Aviation (UK), EASP Air currently receives $€ 26.75$ million for its surveillance work for Frontex. ${ }^{319}$ 


\section{OPERATION MARE NOSTRUM}

As Mare Nostrum was an operation run entirely by Italy, only Italian equipment was used for it. Leonardo and Fincantieri were the main suppliers of this although two Camcopter S-100 UAVs were supplied by Austrian company Schiebel.

\section{Air and maritime assets used in Operation Mare Nostrum ${ }^{320}$}

\begin{tabular}{|l|l|}
\hline COMPANY & TYPE \\
\hline Bell & Two SH-212 helicopters 321 \\
\hline Breguet Aviation & LRMP Breguet Atlantic patrol aircraft \\
\hline \multirow{3}{*}{ Fincantieri } & LPD amphibious vessel \\
\cline { 2 - 2 } & Two Minerva Class corvettes \\
\cline { 2 - 2 } & Two Costellazioni/Comandanti Class patrol vessels \\
\hline \multirow{2}{*}{ Leonardo } & EH 101 helicopter \\
\cline { 2 - 2 } & Medium AW139 helicopter \\
\cline { 2 - 2 } & AW109 Light Utility Helicopter \\
\hline NHIndustries ${ }^{322}$ & Medium-to-heavy SH90 (TRR) helicopter ${ }^{323}$ \\
\hline Piaggio Aero & MM P180 aircraft \\
\cline { 2 - 2 } & PS P180 aircraft \\
\hline Schiebel & Two Camcopter S-100 unmanned aerial vehicles 324 \\
\hline
\end{tabular}

The S-100 has a controversial history, with drones exported for border security used in countries experiencing armed conflict or governed by repressive regimes. The UAE's military was the first customer, buying 40 S-100 systems in 2005. ${ }^{325}$ These were extensively used in the war on Yemen, where at least two of them were shot down. According to the Austrian government, they were originally exported under a civilian licence on the assumption they would be used for border and coast surveillance, but Schiebel stated that it was clear from the beginning that they could be used for multiple goals, including military deployment. ${ }^{326}$

In 2015 the UAE donated two S-100s to the Libyan National Army under the command of General Haftar, one of Libya's aspiring leaders and a major player in the escalating civil war in the country. ${ }^{327}$ The S-100 was not new to Libya: in 2009 Khadaffi bought four of them, which were placed under the command of the $32^{\text {nd }}$ (Khamis) Brigade, the most important pillar of his regime. According to Schiebel, however, their purpose was for monitoring refugees at the borders. In early 2015 one of these S-100s was shot down. ${ }^{328}$

In August 2019 Christopher Sidoti, a member of the UN fact-finding mission to Myanmar, called for an investigation in the possible sale of S-100s to the country. According to government documents, the Ministry of Defence had reserved $\$ 60$ million to buy these drones, some of which were shown on TV as they landed on navy ships in late 2018. Schiebel argued that they were exported for civilian use only, on which basis the Austrian government apparently allowed the export. While evidence points to military use of the drones, Schiebel and the Austrian government refused to give more information, citing confidentiality agreements. They denied that the export failed to comply with EU arms trade regulations and the arms embargo against Myanmar. ${ }^{329}$

Despite these controversies, in November 2018 EMSA selected the drone for a large maritime surveillance service-provision contract, worth €24 million. ${ }^{330}$ EMSA provides drone services to EU member states on request, to assist in a range of surveillance operations, including for border security and combatting irregular immigration. Since 2017, Denmark, Iceland, Italy, Portugal, Spain and, most recently, Croatia, have used these services. ${ }^{331}$ 


\section{OPERATION SOPHIA}

In contrast to Frontex, Operation Sophia published a complete overview of deployed aircraft and ships on its website. An analysis of this data, taking into account industry takeovers and mergers, shows that a few large companies, with their various subsidiaries and joint ventures, are responsible for the bulk of the assets used. Airbus, Leonardo, French Dassault Aviation and US Lockheed Martin, the world's largest arms company, are the most important suppliers of aircraft used in Operation Sophia.

\section{Air assets used in Operation Sophia}

\begin{tabular}{|c|c|c|c|}
\hline COMPANY & OPERATOR & NAME & TYPE \\
\hline \multirow[t]{4}{*}{ Airbus } & Belgium & Alouette III SA316B332 & Helicopter \\
\hline & France & AS 565 Panther333 & Helicopter \\
\hline & Italy & SH90 NFH334 & Helicopter \\
\hline & Spain & CN-235 Vigma D4335 & Maritime patrol aircraft \\
\hline Antonov & Poland & AN-28B1R Bryza & Transport and patrol aircraft \\
\hline \multirow[t]{2}{*}{ Dassault Aviation } & \multirow[t]{2}{*}{ France } & Atlantique 2336 & Patrol aircraft \\
\hline & & Falcon 50 & Business jet (surveillance) \\
\hline Embraer & Greece & Erieye EMB-145H AEW & Command and control platform \\
\hline General Atomics & Italy & Predator & UAV \\
\hline \multirow[t]{4}{*}{ Leonardo } & Germany & AW Sea Lynx MK88337 & Helicopter \\
\hline & Italy & EH101338, AB212 ASW339 & Helicopters \\
\hline & Spain & ESP AB-212340 & Helicopter \\
\hline & UK & Lynx MK8341, AW159 Wildcat342, AW101 Merlin MK2343 & Helicopters \\
\hline \multirow[t]{2}{*}{ Lockheed Martin } & Portugal & P-3C Orion Cup + & Helicopter \\
\hline & Spain & P3-M Orion344, SH-60B Lamps III345 & Helicopters \\
\hline Swearingen-Fairchild Aircraft & Luxemburg & SW3 Merlin III & Maritime surveillance aircraft \\
\hline
\end{tabular}

In relation to maritime assets, some of the main international players in Frontex operations pop up again - notably Damen - but there is a predominance of national shipbuilders from the countries involved. Hence, all ships Italy contributed to Operation Sophia were built by Fincantieri, while all Spanish ships were from Navantia and its predecessors. Similarly, France purchases from DCN/DCNS, now Naval Group, and all German ships contributed to this operation were built by German shipyards. 


\begin{tabular}{|c|c|c|c|}
\hline COMPANY & OPERATOR & NAME & TYPE \\
\hline Almaz Shipbuilding Company & Slovenia & Triglav 11 & Multi-purpose patrol vessel \\
\hline \multirow[t]{2}{*}{ Babcock International } & Ireland & L.É. Samuel Beckett ${ }^{346}$, L.É. Niamh ${ }^{347}$, L.É. James Joyce ${ }^{348}$ & Offshore patrol vessels \\
\hline & UK & HMS Echo $^{349}$, HMS Enterprise ${ }^{350}$ & Survey vessels \\
\hline BAE Systems $^{351}$ & UK & HMS Diamond & Destroyer \\
\hline \multirow[t]{2}{*}{ Bremer Vulkan 352} & \multirow[t]{2}{*}{ Germany } & FGS Augsburg, FGS Mecklenburg-Vorpommern & Frigate \\
\hline & & FGS Mosel & Replenishment ship \\
\hline \multirow{2}{*}{$\begin{array}{l}\text { Damen Schelde Naval } \\
\text { Shipbuilding }\end{array}$} & Netherlands & HNLMS Rotterdam & Landing platform dock \\
\hline & Belgium & Leopold I, BNS Louise-Marie & Frigates \\
\hline \multirow[t]{2}{*}{$\mathrm{DCN}^{354} / \mathrm{DCNS}^{355}$} & \multirow[t]{2}{*}{ France } & $\begin{array}{l}\text { Aconit, Blaison, Commandant Birot, Commandant Bouan, } \\
\text { Commandant Ducuing, Commandant l'Herminier, Courbet, } \\
\text { Enseigne de Vaisseau Jacoubet, Lieutenant de vaisseau Le Hénaff, } \\
\text { Premier Maître L'Her }\end{array}$ & Frigates \\
\hline & & L'Adroit & Offshore patrol vessel \\
\hline \multirow[t]{4}{*}{ Fincantieri } & Italy & San Giorgio, San Giusto, San Marco & Landing platform docks \\
\hline & Italy & Luigi Rizzo ${ }^{356}$, Zeffiro & Frigates \\
\hline & Italy & Cavour, Garibaldi & Aircraft carriers \\
\hline & Italy & Etna & Replenishment ship \\
\hline $\begin{array}{l}\text { Flensburger Schiffbau- } \\
\text { Gesellschaft }\end{array}$ & Germany & FGS Berlin, GS Frankfurt am Main, FGS Rhein, FGS Werra & Replenishment ships \\
\hline \multirow[t]{2}{*}{$\mathrm{HDW}^{357}$} & Germany & FGS Schleswig Holstein & Frigate \\
\hline & Germany & FGS Karlsruhe & Frigate \\
\hline \multirow[t]{4}{*}{ Lürssen Gruppe } & \multirow[t]{4}{*}{ Germany } & FGS Main 358 & Replenishment ship \\
\hline & & FGS Datteln, FGS Weilheim ${ }^{359}$ & Minehunters \\
\hline & & FGS Ludwigshafen am Rhein ${ }^{360}$ & Corvette \\
\hline & & FGS Sachsen ${ }^{361}$ & Frigate \\
\hline \multirow[t]{3}{*}{ Navantia } & Spain & Cantabria & Replenishment ship \\
\hline & Spain & Canaries, Navarra, Numancia, Reina Sofia, Santa Maria, Victoria ${ }^{362}$ & Frigates \\
\hline & Spain & Rayo & Offshore patrol vessel \\
\hline Swan Hunter & UK & HMS Richmond & Frigate \\
\hline
\end{tabular}

\section{VIRTUAL WALL CONTRACTORS}

The systems and databases that comprise the virtual walls of Fortress Europe are aimed at controlling, monitoring and surveilling people's movements. An important part of this is registering people crossing EU external borders on (biometrics based) databases which can be accessed by border, and increasingly also police, authorities.

These systems are fundamental parts of border and migration management policies, facilitating identifying, stopping and expulsing refugees. The same technologies are used for the opposite as well, for example by allowing registered 'legal' travellers to pass border control quick and smoothly. As such they contribute to a system of 'border apartheid', where some can easily pass while others are immediately picked out for stringent controls following generalized threat assessments based on biometrics and features, not in the least skin color. ${ }^{363}$

These systems are also a harbinger of the use of security technology to control society at large, with refugees essentially functioning as guinea pigs for measures later to be introduced on a wider scale. ${ }^{364}$ The increasing use of cameras, ever more refined biometrics registration, motion trackers, emotion recognition software and so on builds a fine-meshed system of control, risk identification and discipline.

Most of the major EU contracts for the so-called virtual walls have gone to two companies, sometimes as leader of a consortium. Sopra Steria is the main contractor for the development and maintenance of VIS, SIS II and EURODAC, while GMV has secured a string of contracts for Eurosur. 
At first glance it is not surprising, and may even seem logical, that the same companies repeatedly get follow-up contracts for certain systems. They build on their own technology, work and knowledge and are already experienced in developing, working with and maintaining these systems. This also creates a risk of dependency, however, where these companies acquire a monopoly-like status, and the EU is almost forced to keep working with them even if they overcharge, miss deadlines or fail to observe data-protection regulations.

\section{SOPRA STERIA TOTAL REVENUE (2018): $€ 4.10$ BILLION $^{365}$}

The French IT consultancy firm Sopra Steria arose from a merger between Sopra and Steria in 2014. It is the prime contractor for several large EURODAC, VIS and SIS II (framework) contracts, winning contracts with a total value of over $€ 150$ million, for some of which it cooperated with HP Belgium, Bull and 3M Belgium.

The road to the launch of SIS II was plagued with technical problems, including failing a series of crucial tests in 2008. This led to years of delay. ${ }^{366}$ On several occasions the European Commission had to pump extra money into the project to keep it running: $€ 8.4$ million in 2008 , with a contract extension, and another $€ 1$ million in 2009. On the other hand, the Commission imposed penalties of $€ 3.5$ million on the consortium for under-performance, delays and non-compliance in the development of both SIS II and VIS. ${ }^{367}$

This was not the only time Sopra Steria was part of a troubled project. As one of the partners in the Trusted Borders consortium, along with US arms giant Raytheon, Serco, Accenture, Detica, QinetiQ and Capgemini, in 2007 the company won a $£ 650$ million contract to implement the UK e-Borders programme. This programme consisted of 'the electronic collection and analysis of data on all travellers entering or leaving the United Kingdom'. The UK Border Agency terminated the contract in 2010, after growing dissatisfaction due to delays and also losing the trust of the airline industry, which had to provide passenger data for the system. ${ }^{368}$

\section{EURODAC, VIS and SIS II contracts Sopra Steria}

\begin{tabular}{|c|c|c|c|}
\hline YEAR & CONTRACT DESCRIPTION & PARTNER COMPANIES & VALUE \\
\hline \multirow[t]{2}{*}{2000} & \multirow[t]{2}{*}{ Providing Automated Fingerprint Identification System (AFIS) for EURODAC ${ }^{369}$} & Cogent Systems & \multirow[t]{2}{*}{ Unknown } \\
\hline & & Bull SAS & \\
\hline 2004 & Development of SIS II and VIS ${ }^{370}$ & HP Belgium & $€ 40,000,000$ \\
\hline \multirow[t]{2}{*}{2013} & \multirow[t]{2}{*}{ Transfer of the Eurodac system to eu-LISA ${ }^{371}$} & 3M Cogent & \multirow[t]{2}{*}{$€ 3,725,480$} \\
\hline & & Bull SAS & \\
\hline \multirow[t]{2}{*}{2014} & \multirow{2}{*}{$\begin{array}{l}\text { Aligning Eurodac with the new requirements in Regulation (EU) No 603/2013 and } \\
\text { maintenance }{ }^{372}\end{array}$} & Bull SAS & \multirow[t]{2}{*}{$€ 7,487,862$} \\
\hline & & 3M Belgium BVBA/SPRL & \\
\hline \multirow[t]{2}{*}{2016} & \multirow[t]{2}{*}{ Capacity upscale of Eurodac system and related maintenance ${ }^{373}$} & Bull SAS & \multirow[t]{2}{*}{$€ 5,226,146$} \\
\hline & & 3M Belgium BVBA/SPRL & \\
\hline \multirow[t]{2}{*}{2017} & \multirow[t]{2}{*}{ Framework contract for maintenance of the Eurodac system ${ }^{374}$} & Bull SAS & \multirow[t]{2}{*}{$€ 22,690,000$} \\
\hline & & 3M Belgium BVBA/SPRL & \\
\hline 2018 & $\begin{array}{l}\text { Framework contract for the maintenance in working order of the Schengen Information } \\
\text { System }\end{array}$ & - & $€ 80,000,000$ \\
\hline
\end{tabular}

Sopra Steria's central role in developing these EU biometric systems has a spin-off effect in securing other national contracts. At the launch of SIS II, the company reported that Belgium, Bulgaria, Czech Republic, Finland, France, Romania, Slovenia and the UK had contracted it to provide an 'off-the-shelf solution' to connect their national system with the central system. ${ }^{376}$ The German border police had also been working with an automated fingerprint system from Steria. ${ }^{377}$ 


\section{GMV \\ TOTAL REVENUE (2018): $€ 196$ MILLION $^{378}$}

GMV is a Spanish technology company, active in multiple sectors, including defence and security. The company has received several large contracts for Eurosur, ever since its testing phase in 2010. While the Eurosur is GMV's biggest contract, it has also provided technology to the Spanish Guardia Civil, such as control centres for its SIVE border security system. ${ }^{379}$ It has also provided software development services to Frontex. ${ }^{380}$

\section{Eurosur contracts GMV}

\begin{tabular}{|l|l|c|}
\hline YEAR & CONTRACT DESCRIPTION & VALUE \\
\hline 2010 & Testing Eurosur network on a pilot basis between Frontex and selected Member States ${ }^{381}$ & $€ 1,500,000$ \\
\hline 2012 & $\begin{array}{l}\text { Two-phase enlargement of the Eurosur project }{ }^{382}-\text { 'provide the necessary capacity for creating a permanent } \\
\text { Connection between the whole set of National Coordination Centers (NCCS) and FRONTEX itself' } 383\end{array}$ & $\begin{array}{l}\text { Unknown } \\
\text { network from its pilot phase into a stable service aligned with the Eurosur legislation }{ }^{\prime 384}\end{array}$ \\
\hline 2014 & $\begin{array}{l}\text { Eurosur evolution, support and maintenance - 'The aim of this framework contract is to evolve the Eurosur } \\
\qquad 12,000,000\end{array}$ & $€ 12,000,000$ \\
\hline
\end{tabular}

GMV has also participated in at least ten EU-funded R\&l projects on border security. GMV was the coordinator of the NEREIDS and SAGRES research projects, financed with $€ 4$ million (of which $€ 0.76$ million went to GMV) and $€ 3.4$ million ( $€ 0.5$ million for GMV) respectively, by the EU under the Framework Programme 7 for R\&I. One of the main aims of NEREIDS, which ran from 2011 to 2014, and SAGRES (2013-14) was to develop satellite observation of maritime areas to support Eurosur. ${ }^{386}$ Other partners in the NEREIDS consortium included Thales and the Dutch research institute TNO. ${ }^{387}$

GMV was also involved in the AEROCEPTER research project, which sought to develop a UAV for the interception of non-cooperative land and sea vehicles to stop irregular migration. For this, the company received $€ 0.22$ million from an EU contribution of $€ 3.47$ million for the consortium that included the Spanish arms company Isdefe (Spain) as well as Israeli Aerospace Industries and the Israeli Rotem Technological Solutions and the Ministry of Public Security of Israel. ${ }^{388}$

Between September 2019 and February 2021 GMV will participate in the ANDROMEDA research project, with $€ 5$ million of EU funding. GMV will receive $€ 411,950$. This project aims to improve the common information-sharing environment (CISE), another EU initiative to achieve greater control by integrating surveillance systems and networks to make information more broadly available. ${ }^{389}$

\section{BULL}

Bull and Cogent, later 3M, have been regular consortium partners with Sopra Steria for work on Eurodac, SIS II and VIS. Cogent was bought by 3M, then by Gemalto and subsequently by Thales. Bull was a French computer company, active in many sectors, including the military and security markets. In 2014 Atos acquired Bull, paying $€ 620$ million for a majority of the shares. ${ }^{390}$

Bull was accused of profiting from selling to repressive regimes in countries outside Europe, fuelling the reasons people are forced to flee, and from building Fortress Europe. In 2007, a subsidiary of Groupe Bull, Amesys, sold the Eagle internet monitoring system to the Khadaffi regime in Libya for approximately $\$ 25$ million. This system was used to spy on citizens and foreign journalists.

In mid-2011 the International Federation for Human Rights (FIDH) accused Amesys of complicity in torture, prompting French authorities to start an investigation into the deal. While this was going on, 
in 2013 Groupe Bull sold the Eagle system and its subsidiary to Nexa Technologies, a company run by Stéphane Salies, the former CEO of Amesys. ${ }^{391}$

In March 2014 the UAE bought an updated version of Eagle, Cerebro, from Nexa as a present for the Sisi regime in Egypt, just after the military coup against President Morsi. Another Salies company, the Dubai-based Advanced Middle East Systems, took delivery of the system and, like Nexa, regularly sends technicians to various sites in Egypt where the system is deployed by the intelligence unit of the Egyptian Ministry of Defence for 'live surveillance of suspects'. ${ }^{392}$

The Egyptian authorities use mass internet surveillance for increasing repression of political opposition. In August 2013, EU member states agreed to install a non-binding ban on exports 'of any equipment which might be used for internal repression' to Egypt. ${ }^{393}$ Many countries, however, ignore this ban and continue exporting military and security goods, including surveillance equipment and software. ${ }^{394}$ In December 2017, the Paris Prosecutor's office started a new investigation into the sale to Egypt, again based on reports by FIDH, together with the Ligue Droits de L'homme (LDH), about Nexa's complicity in torture and enforced disappearances. The investigation was added to the existing one into the exports by Nexa's predecessor (Amesys) to Libya. ${ }^{395}$

\section{OTHER COMPANIES}

Most of the large contracts for the virtual walls that did not go to consortia including Sopra Steria, were awarded by eu-LISA to consortia consisting of other computer and technology companies.

\section{Large contracts for 'virtual walls' - eu-LISA (2013 - 2018) (>€5 million)}

\begin{tabular}{|c|c|c|c|}
\hline YEAR & DESCRIPTION OF CONTRACT & CONTRACTOR(S) & VALUE (MILLION €) \\
\hline 2012 & Maintenance of the VIS/BMS system in operational conditions ${ }^{396}$ & Accenture, Morpho, HP Belgium ${ }^{397}$ & up to $70.00^{398}$ \\
\hline 2013 & Framework contract for the maintenance in working order of SIS II399 & Atos Belgium, Accenture, HP Belgium & 50.00 \\
\hline 2014 & Development phase of a major evolution concerning BMS used by VIS 400 & Accenture, Morpho, HP Belgium & 23.70 \\
\hline 2015 & Realisation of VIS storage upgrade and VIS maintenance extension ${ }^{401}$ & Accenture, Morpho, HP Belgium & 7.85 \\
\hline 2016 & Framework contract for the maintenance in working order of VIS and BMS ${ }^{402}$ & Accenture, Morpho, HP Belgium & 194.45 \\
\hline 2017 & Provision of common shared infrastructure services ${ }^{403}$ & Everis Spain SLU & 40.00 \\
\hline 2019 & $\begin{array}{l}\text { Framework contract for implementation and maintenance in working order } \\
\text { of entry exit system }{ }^{404}\end{array}$ & IBM Belgium, Atos Belgium, Leonardo & 142.05 \\
\hline
\end{tabular}

As well as acquiring Bull, with its problematic history of exporting to authoritarian regimes, Atos has been variously involved in the border walls market. In 2015, it supplied license-plate recognition systems for border control to Spain, which were installed in several Spanish ports and on the borders of Ceuta and Melilla. ${ }^{405}$ Atos developed a positioning system for Frontex (FPS), to track assets deployed in joint operations and calculate their running costs. ${ }^{406}$

In 2006, Accenture, with others including Sagem Défense Sécurité (part of the French company Safran) and Bull, won the $€ 157$ million framework contract to develop the Biometric Matching System (BMS). This system forms a core component of EU identity systems such as VIS. ${ }^{407}$ Accenture used the so-called 'refugee crisis' of 2015 to promote its own biometric identification systems as a means to register refugees swiftly. In one promotional brochure, Accenture argues that 'when a young boy's body washed up on a Turkish shore, the subject of refugees became less about numbers, or a political issue, and more of a humanitarian crisis', but also reproduces the narrative of refugees as a threat to security, writing that '[t]here are terrorists who choose to pose as refugees'. In both cases, Accenture uses the crisis to justify its business. ${ }^{408}$ 
In November 2017, the US Customs and Border Protection (CBP) contracted Accenture to help hire thousands of new border security officers as part of President Trump's plans to close off the border with Mexico. In April 2018 CBP terminated the $\$ 297$ million contract after only a few dozen people had been hired. ${ }^{409}$ In the meantime, Accenture employees had started petitioning the company to cancel the 'unethical and immoral' contract in light of the US government's policy to separate migrant families: 'The technology we provide is sold in the name of efficiency, but all we see is technology supercharging inhumane and cruel policies. [...] We joined Accenture because we want to work for a company that does good in the world, a company that helps vulnerable immigrants, not facilitates putting them into cages'. 410

Morpho was a subsidiary of the large French military company Safran, focusing on biometric identification systems. It has provided biometric identification documents and applications to many countries in and outside Europe. ${ }^{411}$ In 2015, Morpho sold fingerprint scanners to Lithuania to process all visa requests at Lithuanian embassies. This system became part of VIS, with the biometric data stored in a database 'available to border control authorities in countries that are part of the Schengen Area', and was partly financed through the EU External Borders Fund. ${ }^{412}$ In 2017 Safran sold Morpho, which merged with Oberthur Technologies as OT Morpho, later renamed Idemia. ${ }^{413}$

\section{LOBBYING}

As research in the last 15 years has frequently shown, the military and security industries have, through effective lobbying, been very influential in shaping the discourse of EU security and military policies. This has ranged from securing EU funding for security and later military research to the establishment of the European Defence Fund. ${ }^{414}$

With regard to migration, industry has succeeded in positioning its representatives as the experts on border security, pushing the underlying narrative that migration is first and foremost a security threat, to be combatted by security and military means. ${ }^{415}$ As the basis of European migration policies, this premise creates an unending demand for the ever-expanding catalogue of equipment and services for border security and control.

Large arms companies have lobbyists in Brussels, as do the most important lobby organisations, the European Organisation for Security (EOS) and the Aerospace and Defence Industries Association of Europe (ASD). For border security, EOS takes the lead. It has a 'Integrated Border Security Working Group', to 'facilitate the development and uptake of better technology solutions for border security both at border checkpoints, and along maritime and land borders'. The working group is chaired by Giorgio Gulienetti of the Italian arms company Leonardo, with Isto Mattila (Laurea University of Applied Science) and Peter Smallridge of Gemalto, the digital security company that has recently been acquired by Thales, as co-chairs. ${ }^{416}$ ASD also recognises 'border security' as a key issue in the field of security. ${ }^{417}$

Company lobbyists and representatives of these lobby organisations regularly meet with EU institutions, including the European Commission, are part of official advisory committees, publish influential proposals, organise meetings between industry, policy-makers and executives and also meet at the plethora of military and security fairs, conferences and seminars. ${ }^{418}$ In these meetings industry representatives position themselves as the experts on border security, presenting their goods and services as the solution for 'security threats' caused by immigration. ${ }^{419}$ 


\section{Lobbying by main European arms companies and lobby organisations in Brussels $\mathbf{s}^{420}$}

\begin{tabular}{|l|r|r|r|}
\hline NAME & COSTS (2017) & NUMBER OF LOBBYISTS & MEETINGS WITH EUROPEAN COMMISSION (NOV 2014-2019) \\
\hline ASD & $€ 298,000$ & 10 & 30 \\
\hline EOS & $€ 100,000-€ 199,999$ & 5 & 11 \\
\hline Airbus & $€ 1,500,000-€ 1,749,000$ & 11 & 157 \\
\hline Leonardo & $€ 300,000-€ 399,999$ & 3 & 35 \\
\hline Thales & $€ 300,000$ & 3 & 23 \\
\hline
\end{tabular}

Most lobbying in the field of border security seems to concentrate on promoting (new) technologies: Eurosur, biometrics, databases, surveillance and detection technology, and the inter-operability between national and EU systems and databases. In terms of the European border walls, the industry makes little effort to promote walls and fences as such. Given the European Commission's outspoken aversion to physical border barriers, the industry might also consider it obsolete to put much energy in lobbying for these, since this might jeopardise its current good relations with EU institutions. Lobbying seems to focus more on the (more profitable) technology used at walls and in maritime operations, as well as the virtual walls ('smart borders') as a whole, where the relation between industry and public authorities is close. The European Association for Biometrics (EAB) brings together members from industry, governments and academia, including government, police and identification services from Denmark, Germany, Kosovo, the Netherlands and Norway, as well as companies such as Idemia and Sopra Steria. Some employees from eu-LISA and Frontex are also members of the EAB. ${ }^{421}$ Rasa Karbauskaite, Senior Research Officer and manager of the Future of Border Checks project at Frontex, is on the EAB board. ${ }^{422}$ The Head of the Frontex Research and Development Unit, Edgar Beugels and Krum Garkov, executive director of eu-LISA, are members of its Advisory Council.

Every year EAB organises a joint research conference with the Joint Research Centre (JRC) of the European Commission. ${ }^{423}$ Both also are co-organisers of the annual International Conference of the Biometrics Special Interest Group. ${ }^{424}$ The JRC itself enthusiastically promotes the use of biometrics and the European biometrics industry. In 2005, it released a study on the use of biometrics for border security, prepared for the European Parliament. One of its key recommendations is support for the 'emergence of a vibrant European biometrics industry', which depends on two conditions: 'the creation of a demand market based on wide user acceptance' and 'the fostering of a competitive supply market for biometrics'. In other words: the public needs to be pushed to accept biometrics, while a competitive market 'will need kick-starting by governments - in their role as launch customers, not as regulators'. ${ }^{425}$

The influence of the industrial lobby can be seen in the dominant narrative of migration as a security problem, and in its practical implementation: the, sometimes literal, adoption of business policy proposals, the expanding infrastructure of border security and control at and beyond European borders, the militarisation of borders and the increasing budgets for Frontex, EU funding for member states' border security efforts and virtual systems.

Even so, the industry is not satisfied. In a December 2016 memorandum, EOS is highly critical about Eurosur's progress: 'After several years of discussion, the Eurosur regulation has been approved, yet it is hardly applied (or known) in Member States (MS). This situation, unfortunately, does not help solve the interoperability issue, an important technology challenge that should not be tackled "a posteriori". Indeed, border control and migration is not only an issue for public administrations and enforcement bodies, but it needs an adequate technology support, with solutions assuring security and privacy by design'.426 The memorandum goes on to complain about having less direct access to Frontex: '[O]ur 
dialogue with Frontex has been reduced, and only limited bilateral discussions are now possible. We hope for an improved dialogue and cooperation with the new EBCG structure'.

While in 2015, Frontex indeed had changed its policy regarding meeting with industry, this did not mean more distinct contacts, but another way of maintaining them. Overwhelmed by requests for one-to-one meetings, the agency introduced a system of six-monthly industry days and specific workshops and other meetings. Companies can sign up for these, after which Frontex selects the proposals it finds most interesting. ${ }^{427}$ There is certainly no lack of such initiatives, which have been on the rise with the expansion of Frontex and its larger budget.

In October 2019, for example, Frontex organised the International Conference on Biometrics for Borders, inviting industry and research institutions to 'showcase innovative technologies dealing with the use of advanced biometrics and/or with the tackling of its associated vulnerabilities'. The conference also functions as a meeting point for industry and other participants, such as member states' authorities and EU policy-makers and agencies, with 'an exhibition [...] planned as a side event on both days of the conference to connect end-users with technologies and to provide an informal networking environment for all stakeholders present'. ${ }^{228}$

Frontex is not the only EU institution that organises events to strengthen ties with the industry on border security. In February 2018 the European Commission held the 'Industry Day on Border Surveillance and Integrated Border Management' in Brussels in order to meet up with military and security companies to discuss the future development of EUROSUR. There were presentations by leading officials from the Directorate-General for Migration and Home Affairs (DG HOME) of the Commission, Frontex and the European Defence Agency. Giorgio Gulienetti of Leonardo and EOS delivered a speech on 'The role of industry'.429 


\section{CONCLUSION}

As Building Walls showed, Europe - which 30 years ago symbolised the end of walls - is now the leading 'theatre' of various kinds of border walls and fences. This report shows that the EU and member states have pumped billions of euros into building land, maritime and virtual walls. This taxpayers' money has ended up in the pockets of a range of companies: construction firms building the walls, shipbuilders providing the vessels for Frontex operations, biometrics companies developing and maintaining identity databases, and military and security companies that are involved in all of this work.

The EU plans for future border and migration policies show an escalation of the same, promising an ever-increasing revenue stream for border security businesses. While the land border walls remain the responsibility of individual member states, the EU will continue to fund (parts of) the accompanying technology as well as the purchase of new vessels and helicopters for use in Frontex operations, and national centres for integrating into the biometric database systems and Eurosur.

Billions of euros, mostly though the Integrated Border Management Fund, will be made available in the 2021-2027 EU budget cycle. During the same period, Frontex budgets will also be expanded, with €2.2 billion earmarked for purchasing or leasing equipment while funding for the development, setting up and maintenance of the 'smart border' database systems remains considerable.

In short: everything points to a further heightening and strengthening of the walls of Fortress Europe.

Rather than pointing at the humanitarian and political crisis behind this, military, security and biometrics companies frame this as a business opportunity. They see their markets grow and expand. The big players, like Airbus, Leonardo and Thales lead the way in lobbying for more walls and stricter policies, presenting new technologies and gobbling up profitable smaller companies. Others focus on their own niches, selling razor wire for land walls or developing new biometrics applications.

For CEOs it may be just 'work', but there are ethical choices involved - which companies can exercise. Where one razor-wire producer, ESF, thrives on the increase in walls and fences since 2015, another one, Mutanox, publicly stated it would not sell for border fences.

The consequences of these policies, as they become more visible with every new step of securitisation and militarisation, are borne by people who are seeking a safe and liveable future. Heightening, fortifying and expanding the walls of Fortress Europe forces refugees and migrants to take more risks to cross borders, to encounter violence, and to end up living 'illegally' in dire circumstances or in detention, awaiting deportation to unsafe countries of origin. 
For all their consequences, the walls and fences remain predominantly symbolic, aimed at displaying toughness and vigour in handling immigration. They make border crossings more difficult, but in the end people who are fleeing will keep trying to find ways over or around such obstacles, adopting ever more dangerous routes.

More walls, stronger walls, higher walls, are all part of the untenable course of European migration policies, driven by corporate capture based on the industry-promoted narrative of migration as a security threat.

On the one hand, the European Commission has declared that the 'refugee crisis' is over, with fewer migrants at Europe's doors, cleverly omitting to point out that measures to externalise Europe's borders have pushed the deadly consequences of their militarisation to countries and areas where they are less visible. On the other hand, the EU and its member states keep pouring ever more money into ever more border security and control measures.

This will not resolve the crisis, and might even exacerbate it - especially when other European policies, including arms exports, military interventions, unequal trade relations and continuing contributions to climate change, will keep on fuelling the reasons people are forced to flee.

The border walls and the policies behind them benefit no one but far-right politicians and industrial profiteers. 


\section{ENDNOTES}

1. Ainhoa Ruiz Benedicto and Pere Brunet (2018) Building Walls: Fear and securitization in the European Union. Amsterdam: Centre Delàs/TNI/Stop Wapenhandel.

2. UNHCR (2019) Global trends: Forced displacement in 2018. Geneva: UNHCR

3. Linda Polman (2019) Niemand wil ze hebben: Europa en zijn vluchtelingen. Amsterdam: Uitgeverij Jurgen Maas. 9

4. https://missingmigrants.iom.int/region/mediterranean

5. Reece Jones (2018) The Poetry of Build the Wall. JLAG Perspectives Forum - The Border Wall and Beyond: Political and Environmental Perspectives, 28 June; http://clagscholar.org/jlag-perspectives-forum-theborder-wall-and-beyond-political-and-environmentalperspectives/

6. Andy Riga (2019) Trump cited UQAM prof to prove border walls work. She says they don't, Montreal Gazette, 18 January.

7. Chad C. Haddal, Yule Kim and Michael John Garcia (2009) Border security: Barriers along the U.S. international border. Washington, DC: Congressional Research Service, 16 March.

8. Andy Riga (2019) Trump cited UQAM prof to prove border walls work. She says they don't, Montreal Gazette, 18 January.

9. Elisabeth Vallet (2017) Border walls are ineffective, costly and fatal - but we keep building them. The Conversation, 4 July.

10. Lucia Riera Bosqued (2019) Sea-Watch captain Carola Rackete honoured for Mediterranean migrant rescue. euronews, 11 September.

11. Ainhoa Ruiz Benedicto and Pere Brunet (2018) Building Walls.

12. Cas Mudde (2019) The far right may not have cleaned up, but its influence now dominates Europe. The Guardian, 28 May.

13. Ursula von der Leyen (2019) Mission letter to Margaritis Schinas, Vice-President-designate for Protecting our European Way of Life, European Commission, 10 September.

14. Jon Stone (2019) EU accused of adopting 'fascist rhetoric' with new Commissioner For Protecting Our European Way of Life to oversee immigration policy, The Independent, 10 September.

15. The Mediterranean Sea has a length of about 3850 kilometres, the sea between Mauritania and Senegal and the Canary Islands about $900 \mathrm{~km}$.

16. Simplified version of map from: Ainhoa Ruiz Benedicto and Pere Brunet (2018) Building Walls. 8

17. Ainhoa Ruiz Benedicto and Pere Brunet (2018) Building Walls

18. Dan Bilefsky (2010) Walls, real and imagined, surround the Roma, New York Times, 2 April 2010; BBC News (2013) Slovakia 'anti-Roma' wall in Kosice riles EU, 20 August.

19. Ainhoa Ruiz Benedicto and Pere Brunet (2018) Building Walls.

20. Frontex (2018) Frontex launching new operation in Central Med. News release, 1 February.

21. Ainhoa Ruiz Benedicto and Pere Brunet (2018) Building Walls.
22. European Commission (2018) EU budget: Commission proposes major funding increase for stronger borders and migration Press release, 12 June.

23. European Parliament (2019) Migration and asylum: EU funds to promote integration and protect borders. Press release, 19 February.

24. European Parliament legislative resolution of 13 March 2019 on the proposal for a regulation of the European Parliament and of the Council establishing, as part of the Integrated Border Management Fund, the instrument for financial support for border management and visa (COM(2018)0473 - C80272/2018 - 2018/0249(COD))

25. Gabriela Baczynska and Sara Ledwith (2016) How Europe built fences to keep people out. Reuters, 4 April.

26. Sarah Léonard and Christian Kaunert (2019) Refugees, security and the European Union. Abingdon/New York: Routledge; Amnesty International (2015) Fear and Fences: Europe's approach to keeping refugees at bay. London: Amnesty International.

27. Ibid

28. D. Angeli, A. Dimitriadi and A. Triandafyllidou (2014) Assessing the Cost-effectiveness of Irregular Migration Control Policies in Greece, MIDAS Report, October.

29. Clive Leviev-Sawyer (2016) Bulgaria's fence at Turkish border so far has cost close to $170 \mathrm{M}$ leva - deputy interior minister, IBNA, 9 December; Clive LevievSawyer (2017) Bulgarian government gives further 1.2M leva for new section of fence at Turkish border, IBNA, 30 August.

30. Pablo Gorondi (2017) Hungary requests EU funding for border fence, AP, 1 September.

31. Estimate for the total costs; ORF.at, G7-Zaun aus Tirol für die Grenze Spielfeld, 4 December 2015; €0.5 million was paid to the contractor, first for lease, later to buy the fence; Claus Hecking (2018) Dieser Zaun stoppt niemanden - weil keiner kommt, Spiegel, 3 December.;

32. Thomson Reuters 2015) Country says 47,000 migrants have arrived since Saturday after Hungary sealed its frontier, 23 October.

33. The Scotsman (2016) 'Great Wall of Calais' barrier completed for $£ 2$.3million, 13 December.

34. Baltic Times (2019) Construction of $93 \mathrm{~km}$ of fence on Latvian-Russian border completed, 11 March.

35. Thomas Nilsen (2016) Storskog-fence built a few centimeters too close to Russia, Barents Observer, 25 September 2016; Jørn Normann Pedersen, Gjerdet kostet fire millioner å bygge. Nå må kanskje deler av det rives, Nordlys, 25 September.

36. Baltic Course (2019) Estonian govt supports cheaper option for eastern border, 30 August; Cost estimates have been adjusted downward after parts of the plan were scrapped. Earlier estimates ran up to $€ 320$ million; Risto Berendson (2018) Eastern border to require $€ 320$ million, Postimees, 5 July.

37. BBC News (2017) Lithuania plans fence on Russian Kaliningrad border, 17 January.

38. Gabriela Baczynska (2017) EU and Hungary spar over migration ahead of court ruling, Reuters, 1 September. 
39. European Commission (2018) Questions and Answers: Future EU funding for Borders and Migration. Fact Sheet, 12 June. 2018

40. Stefan Alscher (2005) Knocking at the Doors of 'Fortress Europe: Migration and border control in Southern Spain and Eastern Poland. Working Paper 126. San Diego, CA: The Center for Comparative Immigration Studies, University of California, San Diego.

41. AFP (2014) EU hands Spain €10m to fight illegal immigration, 4 June.

42. Gabriela Baczynska and Sara Ledwith (2016) How Europe built fences to keep people out, Reuters, 4 April.

43. AP (2018)Avramopoulos: Progress on migration, but more to be done, 16 May.

44. Gabriela Baczynska and Sara Ledwith (2016) How Europe built fences.

45. European Parliament (2011) Answer given by Ms Malmström on behalf of the Commission to a question about the wall between Greece and Turkey, E-001175/2011, 30 March.

46. Ben Hayes, Steve Wright and April Humble (2015) From refugee protection to militarised exclusion: what future for 'climate refugees', in: Nick Buxton and Ben Hayes (eds.), The Secure and the Dispossessed: How the military amd corporations are shaping a climatechanged world. London: Pluto Press, London.

47. Chris Jones (2017) Market Forces: The development of the EU security-industrial complex. Amsterdam: Statewatch and TNI, p. 20

48. Agustín Rivera (2019) Frontera de Ceuta con Marruecos: cámaras, reconocimiento facial y sin concertinas. El Confidencial, 9 June 2019; European Commission (2018) EU Trust Fund for Africa: new actions adopted to support vulnerable migrants, foster socio-economic development and improve border management in North of Africa. Press release, 14 December.

49. North Africa Post (2019) Spain grants Morocco a €32.2 million aid to control irregular immigration, 24 August.

50. Maximilian Popp (2018) EU Money Helped Fortify Turkey's Border. Der Spiegel, 29 March.

51. AFP (2016) EU attacks Austria's planned 'migrant fence' on Italy border, 13 April.

52. Frontex (2019) Final Annual accounts 2018, Reg. No. 6674, 23 May.

53. Frontex (2019) Budget 2019 VOBU, Reg. No: N/2019, 1 January.

54. From Frontex final accounts: https://frontex.europa. eu/about-frontex/key-documents/?category=finalaccounts

55. Ella Ide (2014) Italy ignores pleas, ends boat migrant rescue operation. AFP, 31 October.

56. European Commission, Frontex Joint Operation 'Triton' - Concerted efforts to manage migration in the Central Mediterranean, memo, 7 October 2014

57. European Union Naval Force Mediterranean Operation Sophia - Media and Public information office, Factsheet EUNAVFOR MED operation Sophia, June 2015.

58. European Union Naval Force Mediterranean Operation Sophia - Media and Public information office, Factsheet EUNAVFOR MED operation Sophia, 30 September 2016.
59. Ibid

60. European Union Naval Force Mediterranean Operation Sophia - Media and Public information office, Factsheet EUNAVFOR MED Operation Sophia, 31 March 2019

61. Ibid.

62. European Union Naval Force Mediterranean Operation Sophia - Media and Public information office, Factsheet EUNAVFOR MED Operation Sophia, 4 June 2019

63. European Commission (2018) A strengthened and fully equipped European Border and Coast Guard, State of the Union 2018, 12 September.

64. Ursula von der Leyen (2019) Opening Statement in the European Parliament Plenary Session, as delivered, Strasbourg, 16 July.

65. Frontex, Explanatory note to the Management Board on the Comprehensive strategy for the acquisition and lease of Frontex own technical equimpent - revised strategic considerations, Management board meeting on 22 January 2019 in Warsaw, agenda point 9.1.

66. Frontex (2018) Procurement Plan 2018, Annex IX to: Frontex, Programming Document 2018-2020, Reg. No. 29062, 10 December 2017; Frontex, Procurement Plan 2019, Annex IX to: Frontex, Programming Document 2019-2021, Reg. No 15891, 18 October.

67. Frontex (2017) Management Board decision 28/2017 adopting the Strategy for the Acquisition and Leasing of Frontex own Technical Equipment, 27 September.

68. Regulation (EU) 2016/1624 of the European Parliament and of the Council of 14 September 2016 on the European Border and Coast Guard and amending Regulation (EU) 2016/399 of the European Parliament and of the Council and repealing Regulation (EC) No $863 / 2007$ of the European Parliament and of the Council, Council Regulation (EC) No 2007/2004 and Council Decision 2005/267/EC, article 39.

69. http://www.europarl.europa.eu/legislative-train/ theme-towards-a-new-policy-on-migration/fileeuropean-border-and-coast-guard-agency; European Commission (2017) European Agenda on Migration: Commission reports on progress in making the new European Border and Coast Guard fully operational. Press release, 25 January.

70. https://www.asktheeu.org/en/request/7171/ response/23358/attach/13/12.December\%202018\%20 Report.pdf

71. Frontex (2017) Management Board decision 28/2017 adopting the Strategy for the Acquisition and Leasing of Frontex own Technical Equipment, 27 September.

72. https://ted.europa.eu/udl?uri=TED:NOTICE:106292018:TEXT:EN:HTML

73. https://ted.europa.eu/udl?uri=TED:NOTICE:228272019:TEXT:EN:HTML

74. https://ted.europa.eu/udl?uri=TED:NOTICE:5092572018:TEXT:EN:HTML

75. https://ted.europa.eu/udl?uri=TED:NOTICE:2506612019:TEXT:EN:HTML

76. https://ted.europa.eu/udl?uri=TED:NOTICE:228272019:TEXT:EN:HTML

77. https://ted.europa.eu/udl?uri=TED:NOTICE:3387342019:TEXT:EN:HTML

78. https://ted.europa.eu/udl?uri=TED:NOTICE:4900102019:TEXT:EN:HTML 
79. https://ted.europa.eu/udl?uri=TED:NOTICE:4874362019:TEXT:EN:HTML

80. https://ted.europa.eu/udl?uri=TED:NOTICE:2068702017:TEXT:EN:HTML

81. https://ted.europa.eu/udl?uri=TED:NOTICE:4621082018:TEXT:EN:HTML

82. But the contract award notice mentions that the purchase is related to the ISF-Borders project 'Purchase of coastal patrol boats' for Frontex.

83. https://ted.europa.eu/udl?uri=TED:NOTICE:5055872018:TEXT:EN:HTML

84. 1,100,000 Danish Krone.

85. https://ted.europa.eu/udl?uri=TED:NOTICE:974292019:TEXT:EN:HTML

86. $164,875,500$ Romanian Leu.

87. https://ted.europa.eu/udl?uri=TED:NOTICE:3473862019:TEXT:EN:HTML

88. https://ted.europa.eu/udl?uri=TED:NOTICE:4151512019:TEXT:EN:HTML

89. European Parliament (2017) Strengthening security checks at Europe's borders. Press release, 25 October.

90. European Commission (2018) Security Union: A European Travel Information and Authorisation System - Questions \& Answers. Fact sheet, 5 July.

91. 2013-2017: EU-Lisa final accounts; 2018-2019: EU-Lisa budgets (commitments).

92. SIS, the predecessor of SIS II, had a budget of $€ 39.7$ million from 18 December 1991 to 31 December 2012; Council of the European Union (2013) Multiannual table of authorised C.SIS installation expenditure quarterly reports of 2012, 12774/13, 25 July.

93. Commission of the European Communities (2004) First annual report to the Council and the European Parliament on the activities of the EURODAC Central Unit, SEC(2004) 557, 5 May.

94. European Commission (2013) Questions and Answers: Schengen Information System (SIS II), Memo, 9 April.

95. Commission of the European Communities (2005) Second annual report to the Council and the European Parliament on the activities of the EURODAC Central Unit, SEC(2005) 839, 20 June.

96. Commission of the European Communities, Commission Staff Working Document on the development of the Visa Information System (VIS) - 2004 Progress Report, SEC(2005) 339, 4 March 2005; Commission of the European Communities, Commission Staff Working Document on the development of the Visa Information System (VIS) 2005 Progress Report, SEC(2006) 610, 10 May 2006.

97. Commission of the European Communities (2006) Third annual report to the Council and the European Parliament on the activities of the EURODAC Central Unit, SEC(2006) 1170, 15 September.

98. Commission of the European Communities (2007) Annual report to the Council and the European Parliament on the activities of the EURODAC Central Unit in 2006, SEC (2007) 1184, 11 September.

99. Commission of the European Communities (2007) Commission Staff Working Document on the development of the Visa Information System (VIS) 2006 Progress Report, SEC(2007) 833, 13 June.
100. European Commission (2010) Annual report to the European Parliament and the Council on the activities of the EURODAC Central Unit in 2009, COM(2010)415 final, 2 August.

101. Commission of the European Communities (2008) Report from the Commission to the Council and the European Parliament on the development of the Visa Information System (VIS) in 2007, COM(2008)714 final, 10 November.

102. European Commission (2010) Annual report to the European Parliament and the Council on the activities of the EURODAC Central Unit in 2009, COM(2010)415 final, 2 August.

103. European Commission (2009) Report from the Commission to the European Parliament and the Council on the development of the Visa Information System (VIS) in 2008, COM(2009) 473 final, 15 September.

104. European Commission (2010) Annual report to the European Parliament and the Council on the activities of the EURODAC Central Unit in 2009, COM(2010)415 final, 2 August.

105. European Commission (2010) Report from the Commission to the European Parliament and the Council on the development of the Visa Information System (VIS) in 2009, COM(2010) 588 final, 22 October.

106. European Commission (2013) Annual report to the European Parliament and the Council on the activities of the EURODAC Central Unit in 2012, COM(2013) 485 final, 28 June.

107. European Commission (2011) Report from the Commission to the European Parliament and the Council on the development of the Visa Information System (VIS) in 2010, COM(2011) 346 final, 14 June.

108. European Commission (2013) Annual report to the European Parliament and the Council on the activities of the EURODAC Central Unit in 2012.

109. European Commission (2012) Report from the Commission to the European Parliament and the Council on the development of the Visa Information System (VIS) in 2011, COM(2012) 376 final, 11 July.

110. European Commission (2013) Annual report to the European Parliament and the Council on the activities of the EURODAC Central Unit in 2012.

111. European Commission (2013) Report from the Commission to the European Parliament and the Council on the development of the Visa Information System (VIS) in 2012, COM(2013) 232 final, 25 April.

112. Including $€ 750,000$ for ETIAS from Frontex 2019 budget; Frontex (2019) Budget 2019 VOBU, Reg. No: N/2019, 1 January.

113. Council of the EU (2019) Council of the EU, Interoperability between EU information systems: Council Presidency and European Parliament reach provisional agreement. Press release, 5 February; Council of the EU (2019) Interoperability between EU information systems: Council adopts regulations. Press release, 14 May.

114. European Commission (2017) Frequently asked questions - Interoperability of EU information systems for security, border and migration management. Fact sheet, 12 December.

115. Caitlin L. Chandler and Chris Jones (2019) EU pushes to link tracking databases. Politico, 15 April. 
116. Laura Aragó and Ludovica Jona (2019) Europa fortifica sus fronteras digitales. La Vanguardia, 25 February.

117. Tony Bunyan (2018a) The interoperability of Justice and Home Affairs databases. Briefing. Statewatch, March; Tony Bunyan (2018b) The 'point of no return': Interoperability morphs into the creation of a Big Brother centralised EU state database including all existing and future Justice and Home Affairs databases. Analysis, Statewatch, May.

118. European Commission (2012) Eurosur: Providing authorities with tools needed to reinforce management of external borders and fight crossborder crime. Press release, 13 December.

119. Regulation (EU) No 515/2014 of the European Parliament and of the Council establishing, as part of the Internal Security Fund, the instrument for financial support for external borders and visa and repealing Decision No 574/2007/EC, 16 April 2014.

120. European Parliament (2016) How the EU budget is spent: Internal Security Fund (ISF), April; European Commission (2018) Proposal for a Regulation of the European Parliament and of the Council on the European Border and Coast Guard and repealing Council Joint Action $n^{\circ}$ 98/700/JHA, Regulation (EU) $n^{\circ} 1052 / 2013$ of the European Parliament and of the Council and Regulation (EU) $n^{\circ} 2016 / 1624$ of the European Parliament and of the Council, COM(2018) 631 final, 12 September.

121. European Commission (2018) Evaluation of the Regulation (EU) No 1052/2013 of the European Parliament and of the Council of 22 October 2013 establishing the European Border Surveillance System (Eurosur), Commission Staff Working Document, SWD(2018) 410 final, 12 September.

122. Ben Hayes (2009) NeoConOpticon; Chris Jones (2017) Market Forces.

123. Visiongain (2017) Visiongain analyst says Border Security market worth $\$ 19.9$ billion in 2018, 18 June; Market Research Future (2017) Border Security Market Research Report - Forecast to 2023, May 2018.

124. Homeland Security Research (2017) Smart Borders, Immigration Enforcement \& Border Security Markets in Europe - 2017-2022, May.

125. See: Mark Akkerman (2018) Expanding the Fortress.

126. See Mark Akkerman (2016a) Border Wars.

127. Richard Connor (2019) Airbus chief slams Germany's Saudi Arabia arms export bans. Deutsche Welle, 16 February.

128. Sylvia Pfeifer, David Keohane and Tobias Buck, (2019) European defence industry wrongfooted by Saudi weapons ban., Financial Times, 2 June.

129. SIPRI (2018) Top 100 arms producing companies in 2017. Stockholm: SIPRI.

130. Airbus SE Unaudited Condensed IFRS Consolidated Financial Information for the year ended 31 December 2018, https://www.airbus.com/content/dam/corporatetopics/financial-and-company-information/FY2018Airbus-FINANCIAL-STATEMENTS.pdf

131. Hensoldt (2018) Hensoldt finalizes separation from Airbus. Press release, 27 September.

132. $\mathrm{SH} 90 \mathrm{NFH}$, produced by NHIndustries, which is owned by Airbus Helicopters (62.5\%), AgustaWestland (Leonardo Helicopters, 32\%) and Fokker Aerostructures (Fokker Technologies, 5.5\%).
133. AS 565 Panther, produced by Aérospatiale, which merged into the Eurocopter Group, now part of Airbus as Airbus Helicopters.

134. CN-235 Vigma D4.

135. Alouette III SA316B, developed by Sud Aviation, manufactured by its successor Aérospatiale, which merged into the Eurocopter Group, now part of Airbus as Airbus Helicopters.

136. Super Puma, http://www.statewatch.org/news/2016/ aug/frontex-serious-incident-reports.pdf (p. 68); Dauphin; AS-365 N3 Dauphin; Hellenic Defence News, 16 March 2010.

137. Eurocopter 145; Baltic News Service (2015) Lithuanian border guard helicopter off to mission in Mediterranean, 27 July; and Eurocopter 135; Baltic News Service (2018) Lithuanian border guards' helicopter leaving for Mediterranean mission, 28 May.

138. Super Puma (2016) Frontex, German helicopter deployed by Frontex helped in arrest of suspected drug smugglers, 1 July.

139. On the European Defence Fund, see: Wendela de Vries (2017) European money for the arms industry. Fact sheet, Stop Wapenhandel, http://enaat.org/eudefence-fund

140. Mark Akkerman (2016). Border Wars.

141. https://cordis.europa.eu/project/rcn/97515/reporting/ en

142. https://cordis.europa.eu/project/rcn/106598/reporting/ en

143. Airbus (2017). Airbus selected by ESA for Copernicus Data and Information Access Service (DIAS), press release, 14 December 2017

144. Sarah Hisham (2019) Using latest tech for border management. Geospatial World, 11 September.

145. ESA (2017) Accessing Copernicus data made easier. Press release, 14 December; Tereza Pultarova (2017) ESA tasks Airbus with streamlining Copernicus data access. SpaceNews, 14 December.

146. Leonardo (2018) Annual financial report at 31 December, https://www.leonardocompany. com/documents/20142/120078/ Annual+Financial+Report+31-12-18+ENG-2.pdf/

147. http://www.statewatch.org/news/2017/feb/eu-frontexoperation-hera-2013-annexes-censored.pdf; Airplane ATR42 was produced by ATR, formed in 1981 by Aérospatiale of France (now Airbus) and Aeritalia (now Leonardo) of Italy.

148. European Political Strategy Centre (2017) Irregular migration via the Central Mediterranean: From emergency responses to systemic solutions. EPSC Strategic Notes, Issue 22, European Commission, 2 February.

149. https://ted.europa.eu/udl?uri=TED:NOTICE:1153522017:TEXT:EN:HTML

150. Jörg Nowak (2019) Drone surveillance operations in the Mediterranean: The central role of the Portuguese economy and state in EU border control. Border Criminologies blog, University of Oxford, Faculty of Law, 26 February.

151. https://ted.europa.eu/udl?uri=TED:NOTICE:106292018:TEXT:EN:HTML 
152. Leonardo (2018) Leonardo deploys its Falco EVO Remotely-Piloted Air System for drone-based maritime surveillance as part of the Frontex test programme. Press release, 6 December.

153. Tom Kington (2017) Leonardo delivers updated Falco drone to Mideast customer. Defense News, 13 November.

154. https://ted.europa.eu/udl?uri=TED:NOTICE:2435282019:TEXT:EN:HTML

155. European Defence Agency (2017) Radar imagery application supporting actionable intelligence. Fact sheet, 3 April.

156. https://ted.europa.eu/udl?uri=TED:NOTICE:1859152017:TEXT:EN:HTML; Telespazio, Telespazio Ibérica will supply the Copernicus service to support the European Union in its security operations outside EU territory, press release, 21 June 2017

157. Mark Akkerman (2018) Expanding the Fortress.

158. Mark Akkerman (2016a) Border Wars; Mark Akkerman (2016b) Border Wars II: An update on the arms industry profiting from Europe's refugee tragedy. Amsterdam: Stop Wapenhandel/Transtional Institute

159. https://cordis.europa.eu/project/rcn/99158/reporting/ en

160. On the European Defence Fund, see Wendela de Vries (2017) European money for the arms industry. Fact sheet, Stop Wapenhandel, May; http://enaat.org/eudefence-fund

161. Leonardo (2018) Leonardo to lead OCEAN2020 program, the first and most important European Defence Agency research tender for naval surveillance technology. Press release, 12 January.

162. Thales (2019) 2018 full-year results. Press release, 26 February.

163. https://www.thalesgroup.com/en/countries/europe/ portugal/defence-portugal; https://www.thalesgroup. com/en/countries/europe/netherlands/defencenetherlands

164. Thales Group (2012) Thales and Aerovision present FRONTEX with UAV for border control. Press release, 16 January.

165. Diane Taylor and Emma Graham-Harrison (2016) EU asks tech firms to pitch refugee-tracking systems. The Guardian, 18 February.

166. https://business.esa.int/projects/services-enabledhaps-thales-alenia-space

167. ASD (2017) White Paper: Proposals in the field of defence and space for the preparation of the $\mathrm{EU}$ Multiannual Financial Framework 2021 until 2027, 28 June.

168. European Commission (2011) Commission Staff Working Paper determining the technical and operational framework of the European Border Surveillance System (EUROSUR) and the actions to be taken for its establishment, SEC(2011) 145 final, 28 January.

169. Kelly Bescherer (2017) Borders, Industry, Logistics: Reflections on the Securitization of Calais. Masterarbeit, Institut für Sozialwissenschaften, Humboldt-Universität zu Berlin, April.
170. Chris Burt (2019) Gemalto now known as Thales Digital Identity and Security with acquisition completed BiometricUpdate.com, 2 April; the purchase was announced in 2017, but needed the approval of many governments, mainly because of EU antitrust concerns; Chris Burt (2018a) Thales and Gemalto merger nears halfway point of required regulatory approvals, BiometricUpdate.com, 10 September; Chris Burt (2018b) European Commission conditionally approves Thales acquisition of Gemalto, BiometricUpdate.com, 13 December.

171. 3M (2017) 3M Completes Sale of Its Identity Management Business. Press release, 1 May.

172. See paragraph on Sopra Steria.

173. Gemalto (2018) Trust in a connected world: Annual Report 2017; Gemalto (2019) Eurodac: the European Union's first multinational biometric system, 25 June.

174. Mark Akkerman (2018) Militarization of European border security, in: Nikolaos Karampekios, Iraklis Oikonomou and Elias G. Carayannis (eds.), The Emergence of EU defense research policy: From innovation to militarization. Cham: Springer.

175. https://cordis.europa.eu/project/rcn/86254/reporting/ en

176. Ibid. 6

177. Stop the Wall, Companies building the Apartheid Wall, 2009.

178. Naomi Zeveloff (2016) Israeli builders behind Gaza Wall see growth in Europe, Africa - and Trump. Forward, 3 August.

179. Dan Williams (2015) Exclusive: Migrant crisis spurs European interest in Israeli border barriers. Reuters, 3 September.

180. Yakoov Lappin (2014) Elbit to build surveillance towers on Arizona's border with Mexico. Jerusalem Post, 2 March.

181. Jerusalem Post (2019) Israeli company wins bid to help secure US border, 27 June.

182. Times of Israel (2017) Israeli firm chosen to build protoype of US border wall with Mexico, 13 September.

183. https://ted.europa.eu/udl?uri=TED:NOTICE:106292018:TEXT:EN:HTML

184. IAI (2018) IAI and Airbus maritime Heron Unmanned Aerial System (UAS) succesfully completed 200 flight hours in civilian European airspace for Frontex. Press release, 24 October.

185. UPI (2012) Heron UAS demonstrated for EU, 10 February.

186. Human Rights Watch (2009) Precisely wrong: Gaza civilians killed by Israeli drone-launched missiles. New York: Human Rights Watch.

187. Ami Rojkes Dombe (2019) IDF to deploy Unmanned Ground Vehicles on Gaza Border. IsraelDefense, 9 June.

188. AFP and Times of Israel Staff (2015) Switzerland to buy 6 Israeli-made surveillance drones. Times of Israel, 8 September.

189. https://ted.europa.eu/udl?uri=TED:NOTICE:4739242018:TEXT:EN:HTML\&src=0

190. Naval Today (2018) EMSA contracts Israel's Elbit for unmanned aerial patrol services, 2 November, EMSA (2018) EMSA contracts additional RPAS for maritime surveillance, emissions monitoring and pollution response. Press release, 28 November. 
191. Elbit (2019) Elbit Systems Commenced the Operation of the Maritime UAS Patrol Service to European Union Countries. Press release, 18 June.

192. Naval Today (2019) Israel's Elbit to supply combat suites for Hellenic Coast Guard patrol vessels, 6 March

193. https://ted.europa.eu/udl?uri=TED:NOTICE:3473862019:TEXT:EN:HTML\&src=0

194. Theodore L Valmas (2019) Hellenic Coast Guard to receive three coastal patrol boats. Jane's Navy International, 25 January.

195. Frontex (2015) Serious Incident Report no. 36, FSC Log: 1631/2015, 20 April, https://deathbyrescue.org/ assets/annexes/5.Frontex_SIR_19.04.2015.pdf; Damen Magazine (2015) Sharing the knowledge, 9 April.

196. https://www.vittoria.biz/en/portfolio/the-shipyard/

197. Tara John (2015) This is why border fences don't work. Time, 22 October.

198. Reece Jones (2016) Borders and walls: Do barriers deter unauthorized migration? Migration Information Source. Migration Policy Institute, 5 October. 2016

199. Eric Schewe (2019) Border walls are symbols of failure. JSTOR Daily, 28 February.

200. Reece Jones (2016) Borders and walls.

201. Phillip Bantz (2019) Report ranks global industries with the highest corruption risks, Law.com, 8 April; Katherine Dixon, Charlotte Linney, Mia Paukovic and Andrew Watson (2018) Out of the shadows: Promoting openness and accountability in the global defence industry. London: Transparency International UK

202. http://concertina.es/en/company/mora-salazar-group/

203. Jan Marot (2016) Flüchtlinge sorgen für gute Geschäfte bei Drahtzaunhersteller, Der Standard, 6 May.

204. http://concertina.es/instalacion-de-concertina-en-lavalla-fronteriza-de-melilla/

205. Giles Tremlett (2005) African migrants die in quest for new life. The Guardian, 30 September.

206. Euro Weekly News Media (2013) Razor wire to prevent immigrants entering Spain, 12 December.

207. BBC News (2018) Ceuta and Melilla: Spain wants rid of anti-migrant razor wire, 14 June.

208. Marion MacGregor (2019) Europe's razor-wire borders in Africa. InfoMigrants, 4 July.

209. Agustín Rivera (2018) Málaga fabrica las concertinas de Europa: ¿Se acaba un negocio de 6 millones al año? El Confidencial, 17 June.

210. Jan Marot (2016) Flüchtlinge sorgen für gute Geschäfte bei Drahtzaunhersteller. Der Standard, 6 May; Matthias Monroy (2015) 'Klingendraht 22' aus Spanien: Das Symbol der Festung Europa. Telepolis, Heise online, 14 September; Deutsche Welle (2015) Hungary removes razor wire at Slovenian border, 26 September.

211. De Tijd (2015) Jubelende maker prikkeldraad onder vuur, 17 September.

212. Tiroler Tageszeitung (2015) Tiroler Grenzzaun in Spielfeld wird wohl länger als geplant, 4 Decmber.

213. ORF.at (2016) G7-Zaun aus Tirol für die Grenze Spielfeld, 4 December.

214. Heute.at (2016) Polizei hat Grenzzaun in Spielfeld gekauft, 28 September; Claus Hecking (2018) Dieser Zaun stoppt niemanden - weil keiner kommt, Der Spiegel, 3 December.
215. OÖNachrichten (2015) Grenzzaun ist bald fertig, aber die Löcher bleiben, 12 December.

216. Thanks to the people from Bordermonitoring Bulgaria (bulgaria.bordermonitoring.eu) for providing information.

217. Clive Leviev-Sawyer (2014) Bulgarian - Turkish border fence farce, IBNA, 28 April.

218. Bivol.bg (2018) Wire fence on Bulgarian border proves 'golden', 7 February.

219. Reporters Without Borders (2018) Bulgaria harasses independent media group again, 8 November; Union of Publishers in Bulgaria (2018) The Media freedom White Paper; also see: Frank Stier (2016) Eisberg der Korruption: Bulgarischer Politiker Peewski, Der Spiegel, 31 January.

220. Kircaali Haber (2017) Bulgaristan'ın Türkiye sınırına çektiği tel örgü pahalıya mal oluyor, 9 January.

221. bne IntelliNews (2018), Bulgaria creates 'golden hole' for corruption as it scraps procurement rules for Turkish border fence repairs, 22 March.

222. Clive Leviev-Sawyer (2018) For the second time, heavy rain brings down fence at Bulgarian-Turkish border, IBNA, 6 December.

223. Caroline Mortimer (2015) Bulgaria builds final part of razor wire fence to keep out refugees, 4 August.

224. European Parliament (2013) Fact-finding delegation of the Budgetary Control Committee to BULGARIA border with Greece and Turkey, 18-20 September 2013, 12 November; https://www.indracompany.com/en/ surveillance-bulgarian-turkish-border; more on Indra in: Mark Akkerman (2016a) Border Wars.

225. Sofia Globe (2019) Bulgarian Border Police get 70 off-road vehicles, costing more than 7M leva, 8 March; https://www.mvr.bg/docs/librariesprovider5/ newsdocs/проектно-предложение-фонд-вътрешнасигурност-1.pdf

226. BBC News (2015) Estonia 'plans Russia border fence' amid Ukraine tensions, 28 August.

227. Nordecon (2016) Minister of the Interior Pevkur: The Piusa border guard station serves as an excellent example for other border guard stations along the external borders of the European Union and NATO, 3 June.

228. Risto Berendson (2018a) Eastern border to require $€ 320$ million. Postimees, 5 July.

229. Oliver Kund (2018b) Miscalculation of the century. Postimees, 8 Feburary.

230. Andres Einmann (2018c) Eastern border could be watered down. Postimees, 5 February; Central European Financial Observer (2018) Estonia mulls applying for EU co-financing of border fence construction, 16 February; Ege Tamm (2019) Europe's most modern border reduced to a fence for now. Postimees, 30 August.

231. Postimees (2019) State to invest five million in border control, 27 August.

232. https://www.defendec.com/post/manage-your-blogfrom-your-live-site

233. O-Mag (2017) An Estonian defence companys technology is tracking terrorists in the Indonesian jungle, 12 June. 
234. Chris Glew (2013) Defendec - Estonia's smart border guard technology. Estonian World, 17 September; AL Defaiya (2013) Defendec unveils new border security management system, 28 November.

235. AL Defaiya (2016) Defendec wins sales in cooperation with US government, 28 March.

236. Defendec (2011) US Embassy donates border security equipment to Albanian Border and Migration Department, 19 December.

237. UAWire (2016) EU transferred equipment worth 2.2 million Euros to Ukraine to strengthen BelarusianUkrainian border, 23 November.

238. Helena Smith (2011) Fortress Europe: Greece bids to stem migrant surge from Turkey with guns, wire and a 'wall'.The Observer, 6 February; International Federation of Red Cross and Red Crescent Societies (2012) An update on the situation of irregular migrants in Greece, 9 May.

239. Eubusiness (2012) EU refuses to fund 'pointless' Greece-Turkey border fence, February.

240. Alexander Besant (2012) Greece completes border wall to keep out immigrants. AFP, 17 December.

241. Rebecca Omonira-Oyekanmi (2012) Syrian refugees 'turned back from Greek border by police', The Guardian, 7 December.

242. Nick Thorpe (2015) Hungary races to build border fence as migrants keep coming. BBC News, 6 August; Virginia Martínez (2015) La frontera de concertinas húngara, negocio para una empresa de Málaga. El País, 16 September. 2

243. Pekarek János (2015), Két műszakban 44 fogvatartott dolgozik a határzár kerítéselemeinek horganyzásán, duol, 4 August.

244. Robert Zaretsky (2015) The tangled history of barbed wire. Boston Globe, 27 September.

245. Nick Thorpe (2017) Hungary hits snags with squad to stop migrants. BBC News, 15 February; France 24 (2017) Hungary asks EU to pay half the cost of antimigrant border fencing, 1 September.

246. https://ted.europa.eu/TED/notice/ udl?uri=TED:NOTICE:446343-2017:TEXT:EN:HTML

247. http://www.igate.Iv/about-us/

248. LSM.LV (2019) Interior police wants to keep former Border Guard chief Garbars in custody, 4 September.

249. UNIAN (2019) Construction of $93 \mathrm{~km}$ of fence on Latvian-Russian border completed - media, 11 March.

250. Baltic Times (2018) Fence on border with Russia targets specifically illegal immigration - Latvian ambassador, 18 January.

251. Baltic News Service (2017a) Fence on LithuaniaKaliningrad border to be completed Wednesday, Delfi, 20 December.

252. Baltic News Service (2017b) Pradedama statyti apsauginè siena pasienyje su Rusija, IQ, 30 May.

253. Baltic News Service (2017c), Lithuania readying to build fence on border with Russia, Delfi, 10 May. 2017

254. Baltic News Service (2017d) Govenrment plans to step up border protection, Delfi, 2 March.

255. AFP, EU says Lithuania can use funds for Russian border surveillance, 17 January 2017

256. BBC News (2015) Stranded migrants battle police on Greece-Macedonia border, 28 November.
257. BBC News (2016) Second fence under construction at Macedonia-Greece border, 12 February.

258. Andrew Byrne (2016) Migrants fear their luck running out at Macedonia's border. Financial Times, 25 January; Sunday Express (2016) Macedonia builds $10 \mathrm{ft}$ razor fence along border with Greece ahead of spring migrant influx, 10 January.

259. See for example, Slovak Spectator (2016) Slovakia sends more police officers to Slovenia, Macedonia, 14 January; Republika (2019) Hungary sends 45 police officers to secure Macedonia's borders and stop illegal migrants, 3 April.

260. ECCHR (2016), Push-backs at the Greek-Macedonian border violating human rights. Case report, September.

261. https://www.iom.int/proc/Special\%20Measure\%20 supporting\%20the $\% 20 \% 20$ former\%20Yugoslav\%20 Republic\%20of\%20Macedonia\%20to\%20manage\%20 its\%20southern\%20border\%20in\%20the\%20context\%20of\%20the\%20European\%20Migration\%20Crisis

262. https://iomskopje.org/special-measure-supporting-theformer-yugoslav-republic-of-macedonia-to-manageits-southern-border-in-the-context-of-the-europeanmigration-crisis/

263. https://www.dat-con-defence.com/references/

264. Tomas Nilsen (2016) Storskog-fence built a few centimeters too close to Russia. The Barents Observer, 25 September; Norway Today (2016) Parts of the border fence at Storskog to be moved one centimeter, 29 September.

265. Al Jazeera (2015) Slovenia starts erecting razor wire on Croatia border, 11 November.

266. MMC RTV SLO (2016) 11 kilometers of panel fencing already stands at the border - total costs around 1, million euros, 25 March.

267. AFP (2015)Slovenia installs razor wire on Croatia border, 11 November.

268. Barbara Eržen (2017) Dobičkonosni državni posli podjetja Minis: Od blokiranih računov do vrtoglavih dobičkov. Z24.si, 4 May.

269. Total Slovenia News (2019) Corruption suspected in deal for anti-migrant border fence with Croatia, 8 March.

270. Transparency International Slovenia (2019) Slovenian government agency challenged over suspicious razor wire contract. Press release, 7 March.

271. Reuters (2019) Slovenia erects more border fence to curb migrant inflow, 22 August; Reporter (2019) V Beli krajini srbsko podjetje Legi-SGS na Kolpi postavlja 40 kilometrov panelne ograje, 22 August.

272. Dusan Stojanovic (2019) Vigilantes in Slovenia patrol borders to keep out migrants. Associated Press, 17 September.

273. Estela Casajuana (2017) Private interests and migratory flows: Regulatory capture by companies active in the field of security? Profundo, 27 January.

274. La Información (2015) Las vallas de Ceuta y Melilla han costado más de 60 millones de euros desde 2005, 8 September.

275. El Pueblo de Ceuta (2018) La Guardia Civil contrata por 17,7 millones el mantenimiento del SIVE para los próximos dos años, 29 July.

276. See Mark Akkerman (2016) Border Wars 
277. European Parliament (2018) Answer given by VicePresident Mogherini on behalf of the Commission on questions about 'Seahorse programme aimed at involving Libya in the EU's monitoring of the Mediterranean', E-007458-17, 29 March.

278. Virginia Rodríguez y Gonzalo Fanjul (2017) La industria del control migratorio: ¿Quién gana en España con las políticas fronterizas de la Unión Europea? porCausa, October.

279. Including one for the temporary joint venture with Indra Sistemas; Asociación Pro Derechos Humanos de Andalucía (2014) Human rights on the southern border - 2014, March.

280. https://ted.europa.eu/udl?uri=TED:NOTICE:1264692018:TEXT:EN:HTML\&src=0

281. José Bautista and Álvaro Bravo (2018) Fact-checking: desmontando las vallas de Ceuta y Melilla en siete pasos. El Salto Diario, 21 December.

282. Lucas de la Cal (2019) El hartazgo se transforma en votos para Vox y PSOE en Ceuta y Melilla. El Mundo, 15 April; Lucía Abellán (2019) El Gobierno prevé empezar a quitar las concertinas antes de final de año. El País, 26 August 2019

283. Value of the contract was $€ 71,747$; El Boletin (2019) El Gobierno inicia los trámites para reformar y modernizar las vallas de Ceuta y Melilla, 3 January.

284. Agustín Rivera (2019) Frontera de Ceuta con Marruecos: cámaras, reconocimiento facial y sin concertinas. El Confidencial, 9 June.

285. Although in Calais (France) many of the security measures, including the walls and fences, are common projects by France and the UK, with the latter funding the bulk of them.

286. See the research undertaken by the Calais Research Network: https://calaisresearch.noblogs.org/ contractors/

287. James Brokenshire (2014) Calais crisis: 'Britain is no soft touch when it comes to illegal immigration'. The Telegraph, 6 September.

288. Matt Broomfield (2016) Calais Jungle wall is completed two months after all the refugees were driven out. The Independent, 13 December.

289. Patrick Kingsley and lan Traynor (2015) EU borders chief says saving migrants' lives 'shouldn't be priority' for patrols. The Guardian, 22 April.

290. See, for example,Yasha Maccanico, Ben Hayes, Samuel Kenny and Frank Barat (2018) The shrinking space for solidarity with migrants and refugees: How the European Union and Member States target and criminalize defenders of the rights of people on the move. Amsterdam: Transnational Institute.

291. See, for example, Human Rights Watch (2018) Greece: Violent pushbacks at Turkey border. New York: Human Rights Watch 18 December; Human Rights Watch (2019) No escape from hell: EU policies contribute to abuse of migrants in Libya. New York: Human Rights Watch, 21 January; Deutsche Welle (2019) EU border force Frontex implicated in migrant abuse, 5 August.

292. https://missingmigrants.iom.int/region/mediterranean; https://migration.iom.int/europe; both accessed on 22 September 2019

293. https://www.damen.com/en/about/key-figures
294. Merijn Rengers and Carola Houtekamer (2018) De doorgeschoten verkooplui van Hollands grootste scheepsbouwer. NRC, 19 October; and other articles: https://www.nrc.nl/dossier/damen/

295. Damen (2015) Safeguarding Italy's borders: an interview with Colonel Angelo Senese. Damen Magazine \#3.

296. Romanian OPV Stefan cel Mare MAI 1105; Damen News (2011) Damen is 'trusted partner' of Romanian Border Police, no 14; Bulgarian coast guard ship Obzor; Europost (2016) Obzor ship joins Frontex operation, 5 February; and two UK border force cutters; UK Border Force (2015a) Home Office sends further support to Mediterranean mission, Home Office, 4 November.

297. Swedish multipurpose vessels KBV 001 and KBV 002; Henrik Ekberg (2017) Nytt uppdrag för KBV i sommar. Sjöfarts Tidningen, 20 February; Frontex (2018) Meet Frontex Officers, 7 March. (https://frontex.europa. eu/media-centre/focus/border meet-frontex-officersiAbzRk); UK border cutter HMC Seeker; UK Border Force (2015b) Border Force cutters return from Mediterranean search and rescue operations, Home Office, 13 October; and Dutch frigate Zr. Ms. Van Amstel; Noventas (2016) Meisje geboren op Van Amstel na redding op zee, 18 June.

298. https://twitter.com/pinofinocchiaro/ status/998570246536654849; Portuguese frigate Don Francisco de Almeida, formerly used by the Dutch Navy, in 2019 another Dutch company, Alewijnse Marine, was contracted to perform a mid-life upgrade for this ship; Alewijnse Marine (2019) Start electrical mid-life upgrades on board Portuguese M-frigates. Press release, 5 February.

299. Dutch frigate Zr. Ms. De Ruyter, which has Thales Smart-L radar; Ministerie van Defensie (2016) Koning bezoekt marineschip op Egeïsche Zee, 17 November.

300. Patrouilleschepen Libië, https://dutcharms.nl/ weapon/ CNLbcEG7uKyoYeCUKOUyO; Sea Watch, Incident report, 21 October 2016.

301. Wendela de Vries (2008) Fregatten voor Marokko. Fact sheet, Campagne tegen Wapenhandel, July.

302. Damen (2016) Six Search and Rescue boats from Damen Shipyards Antalya, 6 November; Martina Fischer (2017) Entwicklungsgelder für militärische Ertüchtigung, Brot für die Welt, 13 June.

303. Damen (2019), Damen signs Phase II contract with International Organization for Migration for nine additional SAR 1906 search \& rescue boats, 19 June

304. Fincantieri (2019) 2018 consolidated financial statements and draft financial statements of the parent company. Press release, 25 February.

305. Cassiopea class patrol boat Libra P 402; Naval Today (2015) Italian Navy rescues almost 500 migrants, 20 January; Fronte (2015) Assets deployed in operation Triton involved in saving 3,000 migrants since Friday. News release, 16 February; and frigate Bersagliere, corvette Fenice and patrol vessels; European Political Strategy Centre (2017) Irregular migration via the Central Mediterranean: From emergency responses to systemic solutions. EPSC Strategic Notes, Issue 22, European Commission, 2 February.

306. P61 patrol vessel, funded by Italy; European Political Strategy Centre (2017) Irregular migration;; Times of Malta (2005) New AFM patrol boat launched in Italy, 25 June.

307. See the paragraph on Leonardo. 
308. The Defense Post (2019) France's Naval Group and Italian Fincantieri sign joint venture deal, 14 June.

309. See, for example https://www.asktheeu. org/en/request/frontex_vessels_under_jo_ triton\#incoming-15036; and https://www.asktheeu.org/ en/request/frontex_vessels\#incoming-14084

310. http://www.statewatch.org/news/2016/aug/frontexserious-incident-reports.pdf; https://www.flickr.com/ photos/133852281@N02/albums/72157664499583230

311. http://www.motomarine.gr/military/index.html

312. Thean Potgieter (2014) The secret South African project team: Building strike craft in Israel, 1975-79. Scientia Militaria, South African Journal of Military Studies, 32(1).

313. Poliția de Frontieră Română (2017) Nava MAI 1101 a predat ștafeta navei MAI 1104 a Poliţiei de Frontieră Române care va supraveghea, timp de 4 luni, frontierele Europei din Marea Egee, 4 September.

314. Kustwacht Nederland (2019) Kustwachtvliegtuig ingezet voor Frontex, 4 April; revised by RUAG; https://www. ipms.nl/artikelen/nedmil-luchtvaart/vliegtuigen-d/ vliegtuigen-d-dornier-228/1169-dornier-228-9; Johanna van Waardenberg (2014) Nederlandse Frontex-inzet professioneel. KMarMagazine 07, 25 September.;European Political Strategy Centre (2017) Irregular migration via the Central Mediterranean: From emergency responses to systemic solutions. EPSC Strategic Notes, Issue 22, European Commission, 2 February.

315. Aviation Daily (2010) Israel's Elbit buys Metro support company M7, 16 December; https://elbitsystems.com/ product/ai-63/

316. Spacemetric (2017) Spacemetric and EASP Air Support Frontex Mission. Press release, 1 September.

317. https://ted.europa.eu/udl?uri=TED:NOTICE:3312242015:TEXT:EN:HTML\&src=0; https://ted. europa.eu/udl?uri=TED:NOTICE:1186562018:TEXT:EN:HTML\&src=0

318. EASP AIR (2019) Frontex EU Border and Coast Guard Agency and NL EASP AIR extend Maritime Surveillance contract. Press release, 6 March.

319. https://ted.europa.eu/udl?uri=TED:NOTICE:3387342019:TEXT:EN:HTML\&src=0; Piloot en Vliegtuig (2019), Nieuw Frontexcontract voor NL EASP AIR, 8 March.

320. Based on the overview of deployed assets by the Italian Navy: http://www.marina.difesa.it/EN/ operations/Pagine/MareNostrum.aspx

321. On the Costellazioni/Comandanti Class patrol vessels.

322. Owned by Airbus (62.5\%), Leonardo (32\%) and Dutch aerospace company Fokker Aerostructures (5.5\%); http://www.nhindustries.com/website/en/ref/thepartnership_151.html

323. Embarked on board of the amphibious vessel.

324. Ibid.

325. Flight International (2005) UAE UAVs delivered, 18 October.

326. Der Standard (2015) 'Profil': Österreichische Drohne im Kampf gegen Houthi-Rebellen eingesetzt, 29 August; Cristoph Zotter (2016) Eine österreichische Drohne für alle Zwecke, Neue Bürcher Zeitung, 28 January.

327. Arnaud Delalande (2019) The rise of Libya's renegade general: How Haftar built his war machine. Middle East Eye, 14 May.
328. defenceWeb (2015) CamCopter crashes in Libya, 16 January.

329. Myanmar Now \& Profil (2019) UN expert calls for EU investigation into Austrian firm that sold drones to Myanmar, 10 August.

330. Schiebel (2018) Schiebel wins contract with European Maritime Safety Agency. Press release, 29 November. https://ted.europa.eu/udl?uri=TED:NOTICE:5451742018:TEXT:EN:HTML

331. EMSA (2019) EMSA RPAS drone service to boost maritime surveillance in Croatia. Press release, 23 July.

332. Developed by Sud Aviation, manufactured by its successor Aérospatiale; Aérospatiale was merged into the Eurocopter Group, now part of Airbus as Airbus Helicopters.

333. Produced by Aérospatiale Eurocopter, which merged into the Eurocopter Group, now part of Airbus as Airbus Helicopters

334. Produced by NHIndustries, which is owned by Airbus Helicopters (62.5\%), AgustaWestland (Leonardo Helicopters, 32\%) and Fokker Aerostructures (Fokker Technologies, 5.5\%).

335. Produced by CASA-Airbus Military.

336. Original model designed by Brèguet Aviation, which later merged with Dassault.

337. Produced by AgustaWestland, now integrated in parent company Leonardo as Leonardo Helicopters.

338. Idem.

339. Produced by Agusta, which merged with Westland Helicopters to AgustaWestland, now integrated in parent company Leonardo as Leonardo Helicopters

340. Produced by Agusta Bell, a cooperation between Bell Helicopter Textron and AgustaWestland (subsidiary of Leonardo, now integrated in parent company as Leonardo Helicopters)

341. Produced by AgustaWestland, now integrated in parent company Leonardo as Leonardo Helicopters.

342. Idem.

343. Idem.

344. Formerly owned by Norway, modernised by EADSCASA; EADS is now Airbus.

345. Produced by Sikorsky, which is owned by Lockheed Martin, previously by United Technologies Corporation.

346. Produced by Appledore, which later became part of Babcock International Group; Appledore shipyard was closed in March 2019.

347. Idem.

348. Appledore Shipbuilders as part of Babcock International Group, Appledore shipyard was closed in March 2019

349. Produced by Appledore, which later became part of Babcock International Group, Appledore shipyard was closed in March 2019

350. Idem.

351. BAE Systems Surface Fleet Solutions, now BAE Systems Maritime - Naval Ships.

352. Closed in 1997; naval shipbuilding division was partly taken over by the Lürssen Gruppe.

353. Owned by the Damen Group. 
354. Later became DCNS and then Naval Group.

355. Now Naval Group.

356. Designed in cooperation with Naval Group.

357. Part of the ThyssenKrupp Marine Systems (TKMS) group, owned by ThyssenKrupp.

358. Produced by Kröger-Werft, which is part of the Lürssen Gruppe.

359. Produced by Lürssen Werf.

360. Idem. Contracted together with Blohm+Voss, also part of the Lürssen Gruppe, for five corvettes (K130 Braunschweig class).

361. Produced by Blohm+Voss, Part of the Lürssen Gruppe.

362. Produced by Bazan, which later merged into Navantia.

363. See for example: Rosa Wevers, Unmasking biometrics' biases: Facing gender, race, class and ability in biometric data collection, Tijdschrift voor Mediageschiedenis, Vol. 21, No. 2, 2018

364. Ainhoa Ruiz Benedicto and Pere Brunet, Building Walls: Fear and securitization in the European Union, Centre Delàs/TNI/Stop Wapenhandel, November 2018

365. Sopra Steria (2019) 2018 Full-year results. Press release, 22 February.

366. Joanna Parkin (2011) The Difficult Road to the Schengen Information System II: The legacy of 'laboratories' and the cost for fundamental rights and the rule of law. CEPS, April; Waldemar Hummer (2013) Die längst fällige Migration vom SIS 1+ zum SIS II (Teil 2). EU-Infothek, 30 April.

367. DataNews (2008) Extra centen voor SIS II-consortium, Knack, 18 september; European Parliament, Progress of SIS II and VIS (debate), 19 October 2009; European Parliament, Subject: Schengen Information System - collection of biometric data, Answer given by Ms Malmström on behalf of the Commission, E-2682/2010, 16 July 2010.

368. Julien Jeandesboz, Didier Bigo, Ben Hayes and Stephanie Simon (2013) The Commission's legislative proposals on Smart Borders: their feasibility and costs, European Parliament - Directorate General for Internal Policies - Policy Department C: Citizens' Rights and Constitutional Affairs, October.

369. Steria (2003) The European Commission chooses Steria's biometrics know-how to process asylum requests and fight illegal immigration. Press release, 14 January; Andreas Wilkens (2003) EU startet Fingerabdruck-Datenbank für Asylbewerber. heise online, 15 January.

370. European Commission (2004) European Commission signs 40M€ contract for SIS II and Visa Information System. Press release, 26 October.

371. https://www.publictenders.net/node/2277615

372. https://ted.europa.eu/udl?uri=TED:NOTICE:2538012014:TEXT:EN:HTML

373. https://ted.europa.eu/udl?uri=TED:NOTICE:1465932016:TEXT:EN:HTML

374. https://ted.europa.eu/udl?uri=TED:NOTICE:4675862017:TEXT:EN:HTML

375. https://ted.europa.eu/udl?uri=TED:NOTICE:2520942018:TEXT:EN:HTML
376. Sopra Steria (2013) Steria successfully launches the second generation Schengen Information System for the European Commission (SIS II). Press release, 8 July.

377. Steria (2005) Biometrics: Steria teams up with the Bavarian police to identify hooligans at the 2006 Football World Cup in Germany. Press release, 11 October.

378. GMV (2019) 2018 Annual report.

379. https://www.gmv.com/en/Sectors/Defense/ BorderSurveillanceSystems/; GMV (2013) GMV helps the Spanish Guardia Civil in its Maritime Surveillance Tasks. Press release, 22 July.

380. https://ted.europa.eu/udl?uri=TED:NOTICE:1834852015:TEXT:EN:HTML

381. European Commission (2011) Impact Assessment accompanying the Proposal for a Regulation of the European Parliament and of the Council establishing the European Border Surveillance System (Eurosur), Commission Staff Working Paper, SEC(2011) 1536 final, 12 December.

382. GMV (2012) Enlargement of the Eurosur border-control project, 10 October.

383. GMV (2013) Annual Report 2012.

384. http://ted.europa.eu/udl?uri=TED:NOTICE:178532014:TEXT:EN:HTML

385. https://ted.europa.eu/udl?uri=TED:NOTICE:3916652018:TEXT:EN:HTML\&src=0

386. https://cordis.europa.eu/project/rcn/106574/

387. https://cordis.europa.eu/project/rcn/99070/

388. https://cordis.europa.eu/project/rcn/106475/factsheet/ en

389. https://cordis.europa.eu/project/rcn/224135/factsheet/

390. Mikaal Ricknäs (2014) Atos succeeds in bid to buy Bull, will boost security and cloud offerings. IDG News Service, 11 August.

391. Erin Gifford (2018) Nexa investigated for sale of surveillance equipment linked to Egypt abuses. CorpWatch, 22 January.

392. Olivier Tesquet (2017) Amesys: Egyptian trials and tribulations of a French digital arms dealer. Télérama, 5 July.

393. Council of the European Union (2013) Council conclusions on Egypt, Foreign Affairs Council meeting, Brussels, 21 August.

394. Amnesty International (2016) EU: Halt arms transfers to Egypt to stop fuelling killings and torture, 25 May.

395. FIDH (2017) Sale of surveillance equipment to Egypt: Paris Prosecutor opens a judicial investigation, 22 December.

396. BMS: Biometric Matching System

397. Bridge3 consortium.

398. Pre-eu-LISA contract, awarded by European Commission (DG Home); Accenture, European Commission selects consortium of Accenture, Morpho and HP to maintain EU Visa Information and Biometric Matching Systems, press release 20 Feburary 2012.

399. https://www.publictenders.net/ node $/ 2557729$ ?page $=412739$ 
400. https://ted.europa.eu/udl?uri=TED:NOTICE:2614972014:TEXT:EN:HTML

401. https://ted.europa.eu/udl?uri=TED:NOTICE:4227022015:TEXT:EN:HTML\&src=0

402. https://ted.europa.eu/udl?uri=TED:NOTICE:2054492016:TEXT:EN:HTML

403. https://ted.europa.eu/udl?uri=TED:NOTICE:571562017:TEXT:EN:HTML; https://www.eulisa.europa.eu/ Procurement/Tenders/LISA\%202016\%20RP\%2001\%20 CSI/Annex\%20I\%20-\%20Executive\%20summary.pdf

404. https://ted.europa.eu/udl?uri=TED:NOTICE:2435282019:TEXT:EN:HTML

405. Atos (2015) Atos signs contract in Spain to supply license plate recognition services for border control, 16 December.

406. https://ted.europa.eu/udl?uri=TED:NOTICE:4113292014:TEXT:EN:HTML\&src=0, contract value: $€ 578,378.35$

407. Accenture (2008) Accenture and Sagem Défense Sécurité win prime contract for European Commission's Biometric Matching System. Press release, 20 October; http://www.nws-sa.com/ biometrics/EU_Matching_CS.pdf

408. Accenture (2015) Empowering border management agencies to aid refugees: Using digital identity management to ease safe resettlement.

409. Geneva Sands (2019) CBP terminates controversial $\$ 297$ million Accenture contract amid continued staffing struggles. CNN, 5 April.

410. Josh Eidelson (2018) Accenture workers petition to end $\$ 297$ million border patrol contract. Bloomberg, 15 November.

411. For more on Safran and Morpho, see Mark Akkerman (2016a) Border Wars.

412. Morpho (2015) Lithuania to equip embassies with MorphoTOP fingerprint scanners. Press release, 4 March.

413. Advent International (2017) Advent International and Bpifrance complete the acquisition of Safran Identity \& Security (Morpho) and create OT-MORPHO, a world leader in identification and digital security technologies, 31 May.

414. Chris Jones (2017) Market Forces: The development of the EU Security-Industrial Complex. Amsterdam: Statewatch and Transnational Institute; Bram Vranken (2017) Securing Profits: How the arms lobby is hijacking Europe's defence policy. Vredesactie, October; see also Frank Slijper (2005) The emerging EU military-industrial complex: Arms industry lobbying in Brussels. TNI Briefing Series No 2005/1. Amsterdam: Transnational Institute and Campagne tegen Wapenhandel; Ben Hayes (2006) Arming Big Brother: The EU's Security Research Programme. TNI Briefing Series No 2006/1. Amsterdam: Transnational Institute and Statewatch; Ben Hayes (2009) NeoConOpticon: The EU securityindustrial complex. Transnational Institute and Statewatch. Amsterdam: Transnational Institute; Matle Luehmann (2011) Lobbying warfare: The arms industry's role in building a military Europe. Brussels: CEO.

415. Martin Lemberg Pedersen (2013) Private security companies and the EU borders, in: Thomas Gammeltoft-Hansen and Ninna Nyberg Sørensen (eds), The Migration Industry and the Commercialization of International Migration. Abingdon: Routledge.
416. http://www.eos-eu.com/border-security

417. https://www.asd-europe.org/border-security

418. See the chapter 'Lobbying for business' in Mark Akkerman (2016a) Border Wars.

419. Martin Lemberg Pedersen (2013) Private security companies and the EU borders. 3

420. All data from LobbyFacts.eu, a joint project of Corporate Europe Observatory and LobbyControl.

421. https://www.eab.org/membership/members.html

422. https://www.eab.org/about/team.html

423. Chris Burt (2018) European Biometrics Association wraps up Research Projects Conference 2018, BiometricUpdate.com, 2 October.

424. https://cast-forum.de/en/workshops/infos/272

425. Joint Research Centre (DG JRC) - Institute for Prospective Technological Studies (2005) Biometrics at the frontiers: Assessing the impact on society. Technical report series, European Commission, February.

426. EOS (2016) Memo - EOS Meeting with Commissioner King on 12 December 2016, 5 December.

427. See Mark Akkerman (2016a) Border Wars. ; email exchanges between Frontex and industry representatives, released under a Freedom of Information request to Frontex; see: http://www. asktheeu.org/en/request/contacts_with_the_defence_ and_se_3\#incoming-8354

428. Frontex (2019) Invitation for Industry \& Research Community for the International Conference on Biometrics for Borders, 15 June.

429. Mark Akkerman (2018) EU and military and security industry meet on future of EUROSUR, 3 February. 
This report examines the business of building walls which has both fuelled and benefited from a massive expansion of public spending by the EU and its member states on border security. It examines the arms, security, and IT firms that provide the technology, assets, software and services for the land, maritime and virtual walls that Europe has constructed since the fall of the Berlin Wall 30 years ago.

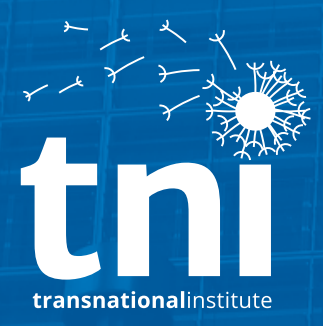

Stop Wapenhandel

www.stopwapenhandel.org
The Transnational Institute (TNI) is an international research and advocacy institute committed to building a just, democratic and sustainable planet. For more than 40 years, TNI has served as a unique nexus between social movements, engaged scholars and policy makers.

Www.TNI.org

Stop Wapenhandel is an independent research and campaign organisation opposed to the arms trade and the arms industry.

www.stopwapenhandel.org

The Centre Delàs is an independent research centre committed to disarmament and peace.

www.centredelas.org 